University of Louisville

ThinkIR: The University of Louisville's Institutional Repository

Electronic Theses and Dissertations

$5-2010$

\title{
The compositional language of Maurice Durufle as manifested in Prelude, Adagio, et Choral Varie, Op. 4 and Quatre Motets, Op.10.
}

Charlyn Dumm 1953-

University of Louisville

Follow this and additional works at: https://ir.library.louisville.edu/etd

\section{Recommended Citation}

Dumm, Charlyn 1953-, "The compositional language of Maurice Durufle as manifested in Prelude, Adagio, et Choral Varie, Op. 4 and Quatre Motets, Op.10." (2010). Electronic Theses and Dissertations. Paper 379. https://doi.org/10.18297/etd/379

This Master's Thesis is brought to you for free and open access by ThinkIR: The University of Louisville's Institutional Repository. It has been accepted for inclusion in Electronic Theses and Dissertations by an authorized administrator of ThinkIR: The University of Louisville's Institutional Repository. This title appears here courtesy of the author, who has retained all other copyrights. For more information, please contact thinkir@louisville.edu. 
THE COMPOSITIONAL LANGUAGE OF MAURICE DURUFLE AS MANIFESTED IN PRELUDE, ADAGIO, ET CHORAL VARIE, OP. 4 AND QUATRE MOTETS, OP. 10

By

\author{
Charlyn Dumm \\ B.A., University of Houston, 1974 \\ A Thesis \\ Submitted to the Faculty of the \\ School of Music of the University of Louisville \\ in Partial Fulfillment of the Requirements \\ for the Degree of \\ Master of Music \\ Division of Music Theory and Composition \\ School of Music \\ University of Louisville \\ Louisville, Kentucky
}

May, 2010 


\section{Copyright 2010 by Charlyn Dumm}

All rights reserved 
THE COMPOSITIONAL LANGUAGE OF MAURICE DURUFLE AS MANIFESTED IN PRELUDE, ADAGIO, ET CHORAL VARIE, OP. 4 AND QUATRE MOTETS, OP. 10

By

Charlyn Dumm

B.A., University of Houston, 1974

A Thesis Approved on

April 22, 2010

by the following Thesis Committee:

Thesis blrector 


\section{DEDICATION}

This thesis is dedicated to my parents

Charles Brownlee and 'lyn Brownlee,

who sacrificed so that I could study music. 


\section{ACKNOWLEDGEMENTS}

I am grateful to those who have contributed to the success of this thesis.

My colleague and friend, McDowell Fogle, provided the idea for the study, suggesting that the search for Gregorian chant in the works of Maurice Duruflé might interest me. My advisor and mentor, Dr. Anne Marie de Zeeuw, worked countless hours on this project and generously offered continual guidance and support. Dr. Steve Rouse encouraged my return to graduate school, thereby making the thesis possible; his advocacy and the suggestions he proffered contributed to this achievement. Dr. Jack Ashworth read numerous drafts, offering his insightful comments. His expertise in chant and organ were invaluable to the paper. My husband Gene spent many hours formatting the paper and helping with the creation and insertion of musical examples; his patience and encouragement sustained me throughout the process. I am grateful to the publisher of Maurice Duruflé's music, Durand-Salabert-Eschig (Universal Music Publishing Group), for permission to reprint musical excerpts and to their representative, Nelly Quérol, for her prompt response to my request. 


\begin{abstract}
THE COMPOSITIONAL LANGUAGE OF MAURICE DURUFLE AS MANIFESTED

IN PRELUDE, ADAGIO, ET CHORAL VARIE, OP. 4 AND QUATRE MOTETS, OP. 10

Charlyn Dumm
\end{abstract}

April 22, 2010

The works of Maurice Duruflé (1902-1986) comprise a small but significant body of sacred music and compositions for organ, yet they have received little serious analytical attention. The present study examines an early organ work, the Prélude, Adagio, et Choral varié, Op. 4, and a late choral composition, Quatre Motets, Op. 10. Duruflé's treatment of form, tonal regions, counterpoint, harmony, and pitch-class collections are investigated, along with use of Gregorian chant fragments and cantus firmi. Elements of Duruflés uniquely personal musical language include the transplantation of Gregorian chant into tertian and quartal/quintal harmonic environments, the use of whole-tone and octatonic collections along with church modes and the prevalent movement of pitch centers by tritone or third. The Prélude, Adagio, et Choral varié and Quatre Motets demonstrate that, throughout his career, Duruflé derives his compositional language from a range of stylistic periods, including French late Romanticism, neoclassicism, and impressionism. 


\section{TABLE OF CONTENTS}

PAGE

APPROVAL / SIGNATURE PAGE ……………………......................... ii

DEDICATION ..............................................................................

ACKNOWLEDGMENTS …................................................................. iv

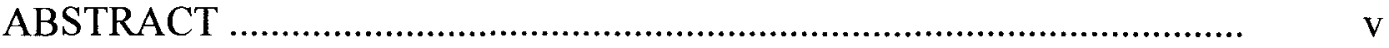

LIST OF EXAMPLES ...................................................................... vii

I. INTRODUCTION AND REVIEW OF LITERATURE..............................

Chapter I Endnotes ............................................................................

II. DURUFLE AND THE CHANT REVIVAL MOVEMENT......................... 8

Chapter II Endnotes ........................................................................... 12

III. PRELUDE, ADAGIO, ET CHORAL VARIE, OPUS 4 ........................... 13

Chapter III Endnotes .........................................................................

IV. QUATRE MOTETS ....................................................................... 52

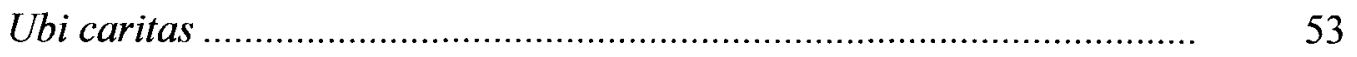

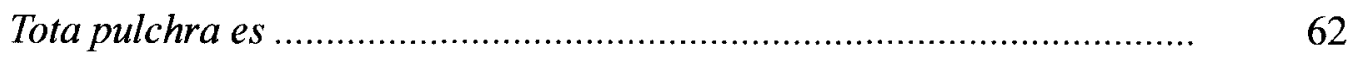

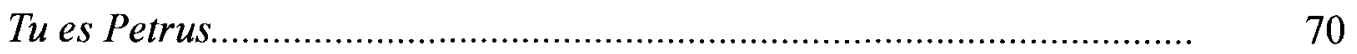

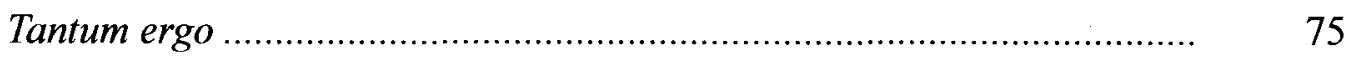

Chapter IV Endnotes ........................................................................

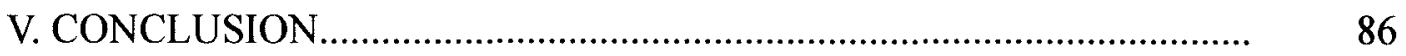

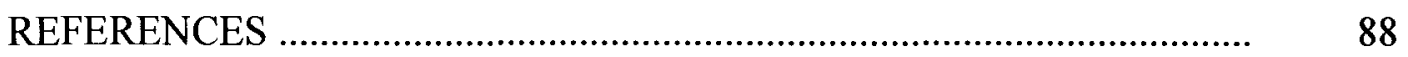

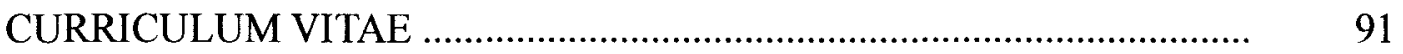




\section{LIST OF EXAMPLES AND TABLES}

1. Veni Creator Spiritus with transcription ........................................ 14

2. Motivic gestures forming the first phrase of the chant ................... 15

3. Motivic Gestures forming the second phrase of the chant ............. 16

4. Third phrase of the chant ……………………………………..... 16

5. Fourth phrase of the chant ......................................................... 17

6. Fragments of the chant with their corresponding placement in the first two measures of Duruflés Prélude

7. Use and location of a rising three-note motive in the first thirtyfour measures

8. Organizational scheme of the Prélude ......................................... 21

9. Audibly conspicuous gestures in the Prélude ……….................... 23

10. Development of the second phrase …………………..................... 25

11. Octatonic/whole-tone pitch collection in $\mathrm{mm}$. 51.4-54 .................. 26

12. Comparison of mm. 1.4-2.2 and mm. 78.4-79 ........................... 27

13. Comparison of the $2+3$ pattern in $\mathrm{mm}$. 1-8 and $\mathrm{mm}$. 71-78 .......... 28

14. Hybrid Octatonic/whole tone pitch collection .............................. 30

15. Contour of the first phrase on Veni creator throughout mm. 7-12. 33

16. Stretto in the soprano and tenor .................................................... 34

17. Third phrase of the chant, transposed and compared to the pedal line of mm. 32-39 
18. The first five notes of the chant are transposed and used in the top voice of the manuals .......................................................... 36

19. Parallel fifths in the Adagio .......................................................... 37

20. Comparison of Prélude mm. 1-4 with Adagio mm. 30-33 ............ 38

21. Development of the $2+3$ pattern in the Adagio mm. 40-43, compared with the Prélude mm. 5-8 ............................................ 39

22. Descending Mixolydian scale embedded in the tenor ..................... 43

23. Soprano/pedal duet in Variation I ................................................ 44

24. The realized sound of the opening of Variation II .......................... 46

25. Chant pitches in mm.49-54, as identified by Duruflé's tenuto marks ................................................................................. 48

26. Right hand and pedal statements of the cantus firmus in $\mathrm{mm}$.

$55-77$ of the fourth variation ...........................................................

27. Mm. 93-94: first and third phrase statements ................................ $\quad 50$

28. Ubi caritas ……………………………….......................... 54

29. Transcription of two versets of Ubi caritas ................................... 55

30. Text and translation of Ubi caritas ............................................... 56

31 Chant passages in Ubi caritas compared with the motet melody... 58

32. Final verset of the chant adapted as "Amen" melisma melisma ... 60

33. Tota pulchra es, Maria .................................................................. 62

34. Transcription of Tota pulchra es, Maria ………….......................... 63

35. Text of Tota pulchra es, Maria …………………..........................

36. Comparison of the first phrase of the antiphon with the motet ..... 65

37. Comparison of the chant "originalis" with the motet .................... 66

38. Derivation of Alto I, mm. 16-18 …………………………............ 67

39. Comparison of the third antiphon of the chant with mm. 36-37 ... 68

40. Comparison of chant and motet on the words honorificentia populi 
41. Tu es Petrus ................................................................ $\quad 70$

42. Chant transcription ........................................................... 71

43. Uses of aedificabo in the soprano ..............................................

44. Cycle of fifths, mm. 13-15 ....................................................... 74

45. Tantum ergo ...................................................................... 76

46. Transcription of the chant ..................................................... 76

47. Text and translation of Tantum ergo ...................................... 77

48. Prominent melodic motives in the chant .................................... 78

49. Soprano/tenor canon in Tantum ergo ......................................... 79

50. Embedded Phrygian scales ...................................................... 80

51. Contrary motion in the Amen cadential formula in mm. 5-7 ....... 81

52. Cadence, mm. 17-19, with the cadential formula at multiple transpositional levels ........................................................... $\quad 82$

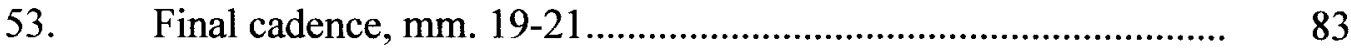

$\begin{array}{ll}\text { Table Page } & \text { Par }\end{array}$

1. Summary of Duruflé's use of chant materials in Ubi caritas ..... 59

2, Formal organization of Tota pulchra es,.................................. 64 


\section{CHAPTER I}

\section{INTRODUCTION AND REVIEW OF LITERATURE}

The French organist and composer Maurice Duruflé (1902-1986) published only fourteen original works and some transcriptions, most of them for organ or chorus. Although a composer of the twentieth century, Duruflé drew inspiration from musical elements of past centuries. His compositions are tonal, modal, or centric and often use Baroque forms, Gregorian chant, and impressionistic elements.

Although scholars have discussed Duruflé's work in a pragmatic way that is helpful to performers and conductors, there is a dearth of thorough analytic investigation of his music. Some studies have focused on one or more of Duruflé's compositions, while others touch on them in the course of discussing a related subject.

A few specifically address Duruflé's choral music. ${ }^{1}$ Alviani and Brookins present short analyses. Alviani comments only on characteristics of melody, harmony, rhythm, and form in the first three of Duruflé's motets and in two excerpts from Duruflé's Messe Cum jubilo; this work also discusses some pieces by Hugo Distler. Brookins writes a few sentences about each choral piece composed by Duruflé. Reynolds offers longer analyses of Opp. 9, 10, 11, and 12, emphasizing the inclusion of Gregorian chant. He includes a variety of charts, tables, and lists, as well as his translations of two articles by Duruflé. 
Mendoza discusses the Solesmes method of chant performance, applying it to Messe Cum jubilo.

Other authors address their comments to conductors. ${ }^{2}$ Caldwell explores the relevance of Solesmes interpretational practices, focusing on the relationship between plainchant notation and the conducting gesture, and offers suggestions for directing the motets. Eaton prepares conductors with structural analyses of the movements of the Requiem and with suggestions for choral interpretation and organ registrations. Jarjisian's rehearsal guide for the Requiem spotlights Gregorian influence. Kano's stylistic interpretation of the same piece relies heavily on observations of text painting and suggestions for realizing mood. William John McIntosh discusses the Solesmes method, explores ways in which the mode and rhythm affect Opp. 9, 10, and 11, and provides textual background and analysis of each of those works.

Seven scholars contribute to a discussion for performers of Duruflé's organ works ${ }^{3}$ Bunn and Singley provide performance guides for Op. 7, Prélude et Fugue sur le nom d'Alain; Bunn addresses the nature and extent of impressionistic practices, and Singley discusses it considering Duruflé's neoclassicism. Driscoll contributes a performance guide for Duruflé's Opus 4, and Cox discusses the Duruflé Suite for Organ, Op.5, examining the development of the suite and providing a short performance guide. Rubis analyzes Opp. 2 and 5 with particular emphasis on hypermeter, presents a survey of contemporary studies in metric accent and hierarchical rhythms, and concludes with implications of hypermeter for musical performance and suggestions for research. 
Herndon Spillman, ${ }^{4}$ an international concert organist, studied with Duruflé for two years before writing his lengthy dissertation intended as an interpretation of the repertoire. The document contains the efforts of the author to count and catalog each chord quality and nonharmonic tone of the organ works. It provides a glimpse into the analytic processes current in the 1950s. For instance, the author misclassifies quartal and quintal harmonies as tertian and misidentifies an $\mathrm{F} \#$ major/C major polychord as a tertian fifteenth chord. John Stuart McIntosh's 1973 dissertation ${ }^{5}$ is an authorized biographical sketch which contains an analysis of Opp. 2, 4, 5, and 7. An appendix includes the exchange of letters between Dr. McIntosh and the composer and his publisher. McIntosh misidentifies "keys" of the Prélude by assigning any modal section the label "minor."

Dissertations devoted to such topics as chant, impressionism, contemporary French choral music, contemporary theme and variation form, and the Vichy government music commissions often include some discussion of Duruflé's works. ${ }^{6}$ Dorroh's study, for example, groups multiple compositions of six twentieth-century French organ composers by the method in which plainsong is revealed: complete exposure of chant throughout the composition without interruptions; complete melody written in short phrases but interrupted with phrases of free composition or imitation; melody revealed in episodic treatment; and Gregorian fragments present without any complete statement. An analysis of Duruflé's Opus 4 is included in the group that reveals the cantus firmus in episodic material. Fazio traces the historical use of the chant Veni Creator Spiritus.

Similarly, McCandless explores the Solesmes treatment of chant, contrasting that to its usage in compositions by Distler, Barber, Bartók, Ives, Berg, Copland, Hindemith, 
Stravinsky, Dello Joio, and Duruflé. Zehr traces the history of the chant Veni Creator and comments on the many compositions through the centuries based on that tune. Fazio traces the use of the hymn in organ works. In his dissertation, Morrison summarizes Robert Mueller's thoughts about the inadequacy of former theoretical approaches for analyzing impressionist music, introducing contemporary principles of tonal organization, including the tonal pillar. ${ }^{7} \mathrm{He}$ graphs motivic-harmonic sonority elements. This analysis of Duruflé's Op. 4 includes conventional motivic and formal analysis. Cooksey seeks to determine the extent of impressionist practices in French organ literature between 1900 and 1960, which includes the period in which Duruflé was writing. He lists compositional characteristics and sorts examples of varied instrumentation from 320 chosen compositions by seventy composers, analyzing to see if those characteristics are evident. He concludes that, with a few exceptions, composers before 1930 were committed to the French Romantic style. He includes a list of late nineteenth and early twentieth-century composers grouped by style. Rhoades recounts the history of variation form, making general observations on the variation movements of Alain, Barber, Distler, Dupré, Duruflé, and Sowerby. He includes the final movement of Duruflé's Opus 4. In his Ed.D. dissertation, Valante briefly comments on thirty composers arranged in this order: impressionists; postimpressionists; Les Six; composers influenced by Les Six; and composers not fitting any of these groups. Chapters are devoted to the Debussy Le Martyre de Saint Sébastien, the Paray Mass for the 500th Anniversary of the Death of Joan of Arc, the Duruflé Requiem, and the Poulenc Gloria. Each segment of these major works receives "interpretive analysis," which includes one 
or more paragraphs about each. Appendices include a catalogue of choral works by twentieth-century composers and supplementary references listed by composer. Sprout discusses the French government's commissions department, 1938-1950, and lists composers who accepted commissions and the amounts paid for specific pieces. The Duruflé Requiem is among those listed. ${ }^{6}$

Two books written specifically about Duruflé are available. ${ }^{8}$ Maurice Duruflé (1902-1986): The Last Impressionist, edited by Ronald Ebrecht in 2002, includes chapters by James Frazier, Marie Rubis Bauer, Jeffrey Reynolds, Herndon Spillman, and Marie-Claire Alain. Frazier's 2007 book, Maurice Duruflé: The Man and His Music, is a complete biography of the composer with brief remarks on each work.

The present study will attempt to fill part of the analytical lacuna left by the abovementioned works. It will examine comprehensively four motets, namely Quatre motets sur des thèmes gregoriens, Op. 10 and a three-movement organ work, Prélude, Adagio et Choral varié, Op. 4. Although some analysts have written about these compositions, their work is misleading ( identifying "key," for example), and limited to discussion of large formal plans, and, in the case of the motets, the text. This paper will discuss the harmonic language and scalar material used in these works, identify and trace motivic fragments derived from the chant melodies, and address neoclassical and impressionist influences as well as the union of those influences with Gregorian chant. The fourth motet, Tantum ergo, almost completely neglected in extant writings, will receive appropriate attention. 


\section{CHAPTER I ENDNOTES}

1. Henry Anthony Alviani, "Use of Cantus Firmus in Selected Sacred Choral Works of Hugo Distler and Maurice Duruflé" (Master's thesis, California State University, Fullerton, 1980); John Barton Brookins, "The Use of Chant in the Choral Works of Maurice Duruflé" (Master's thesis, Southwestern Baptist Theological Seminary, 1988); Michael D. Mendoza, "The Use of Chant and the Influence of the Solesmes Method of Chanting in the Compositional Style of Maurice Duruffé's Messe Cum Jubilo" (Diss., The University of Arizona, 1984); Reynolds, Jeffrey W. "The Choral Music of Maurice Duruflé" (Master's thesis, University of Illinois, 1991).

2. Rodney Hildred Caldwell, "Rhythmic and Metrical Groupings of Chant Notation as an Influence Upon the Conducting for the Quatre motets sur des thèmes grégoriens, Op. 10, of Maurice Duruflé" (Document, The University of Arizona, 1995); Robert P. Eaton, "Maurice Duruflé's Requiem, Op. 9: An Analysis for Performance" (Master's thesis, University of Hartford, 1991); Peter. G. Jarjisian, "The Influence of Gregorian Chant on Maurice Duruflé's Requiem, Opus 9" (Diss., The University of Wisconsin, 1991); Thea Kano, "Visions of a Tranquil End: The Expressive and Stylistic Interpretation of Maurice Durufle's Requiem, Opus 9" (Diss., University of California, Los Angeles, 2004); William John McIntosh, "Modal and Rhythmic Implications of Gregorian Chant Themes Used in the Choral Music of Maurice Duruflé" (Diss., California State University, Long Beach, 1999).

\section{J. Gregg Bunn, "A Performer's Study of Three Préludes and Fugues for Organ} Representing Eighteenth Century Germany, Nineteenth Century Germany, and Twentieth Century France: Johann Sebastian Bach, Franz Liszt, and Maurice Duruflé" (Document, Southwestern Baptist Theological Seminary, 2004); Henry Ellis Singley III, "A Performer's Study of Three Multimovement Organ Compositions Representing Eighteenth Century France, Eighteenth Century Germany, and Twentieth Century France: Boyvin, Bach, Duruflé" (Document, Southwestern Baptist Theological Seminary, 1995); Brian Scott Driscoll, "Maurice Duruflé's Prélude, Adagio et Choral varié sur le theme du 'Veni Creator': A performance guide" (Diss., University of California, Los Angeles, 2004); Marie E. Rubis, "Larger Metric Structures in Two Organ Works by Maurice Duruflé" (Diss., University of Kansas, 1991). 
4. Herndon Spillman, "The Organ Works of Maurice Duruflé” (Diss., Indiana University, 1976).

5. John Stuart McIntosh, “The Organ Music of Maurice Duruflé” (D.M.A. paper, University of Rochester, 1973).

6. William James Dorroh, Jr., "A Study of Plainsong in the Organ Compositions of Six Twentieth-Century Composers" (Diss., George Peabody College for Teachers, 1978); William Edgar McCandless, "Cantus Firmus Techniques in Selected Instrumental Compositions 1910-1960" (Ph.D. diss., Indiana University, 1974); Maria Goretti Zehr, "Selected Organ Compositions Based Upon the Hymn Veni Creator Spiritus" (Diss., Indiana University, 1979); Steven Lee Cooksey, "Impressionistic Aspects of TwentiethCentury French Organ Literature" (Diss., Washington University, 1972); Larry Lynn Rhoades, "Theme and Variation in Twentieth-Century Organ Literature: Analyses of Variations by Alain, Barber, Distler, Dupré, Duruflé, and Sowerby" (Diss., The Ohio State University, 1973); Harry Robert Valante, "A Survey of French Choral Music of the Twentieth Century with a Performance and Interpretive Analysis of Selected Works" (Ed.D. Diss., Columbia University, 1968); Leslie A. Sprout,"Music for a 'New Era': Composers and National Identity in France, 1936-1946" (Diss., University of California, Berkeley, 2000); Leanne Hemphill Fazio, "Selected organ settings of 'Veni Creator Spiritus' from 1470-1964: A historical perspective" (Diss., The University of Alabama, 1990).

7. Donald Nauman Morrison, "Influences of Impressionist Tonality on Selected Works of Delius, Griffes, Falla, and Respighi, Based on the Concept Developed by Robert Mueller" (Diss., Indiana University, 1960); Robert Mueller, "The Concept of Tonality in Impressionistic Music" (Diss., Indiana University, 1954).

8. Ronald Ebrecht, ed., Maurice Duruflé 1902-1986: The Last Impressionist. (Lanham, MD: Scarecrow Press, 2002); James E. Frazier, Maurice Duruflé: The Man and His Music (Rochester, NY: University of Rochester Press, 2007). 


\section{CHAPTER II}

\section{DURUFLE AND THE CHANT REVIVAL MOVEMENT}

The practice of incorporating plainchant into polyphonic compositions extends as far back as the twelfth century when the Notre Dame composers used chant as the foundation of their works. Composers continued to borrow chant for creating motet and mass settings throughout the Middle Ages and Renaissance. ${ }^{1}$

For a variety of reasons the performance of chant had become somewhat corrupt by the early sixteenth century, and following the Council of Trent, Pope Gregory XIII drafted Palestrina to come up with a purified version. ${ }^{2}$ The performance of chant subsequently suffered further degradation, and interest in restoring it to its original state recurred in the middle of the nineteenth century.

In the 1880s, the scholars of the Ecole Niedermeyer ${ }^{3}$ attempted to bring the practice of chant into conformity with medieval practice insofar as they understood it. Subsequently, the monks at Solesmes began chant restoration beginning in 1883 under the oversight of Dom Gueranger, the first abbot of the Benedictine Abbey of Solesmes. ${ }^{4}$ The efforts of the Solesmes scholars yielded the Liber Usualis $(1896)^{5}$, a book containing their versions of the most commonly used chants of the Mass and Office. In 1903, Pope Pius X published the encyclical Motu proprio, an essay of instruction on sacred music, 
which designated the Solesmes method of singing chant as the standard for the Roman Catholic church.

Just one year following this encyclical in which the Catholic Church embraced Gregorian chant and urged its use in liturgy, Maurice Duruflé was born in Louviers, France. He studied with the Benedictines of Solesmes in his childhood, immersed in chant and modal music.

Duruflé's love for and knowledge of these is apparent in his compositions, both in his choice of subject and medium and in his compositional techniques. He wrote predominantly for organ and chorus, both common in music ministry, using Biblical and liturgical texts. The continuity of Duruflé's musical line, resulting from the combination of phrase elision, connected movements, and the avoidance of sudden changes in motion, dynamic level, or rhythm, is reminiscent of chant. Cadences, cadential approaches and departures are non-disruptive, as are transitions between movements. Duruflé slows rhythmic activity and harmonic rhythm at structural changes in the music and frames forward movement at cadences. His musical language is formed by the modes of chant, and chant pervades his compositions.

Other influences on Duruflé's musical language were related to the development of the Cavaillé-Coll organ, which coincided with the reemergence of Gregorian chant. The innovations of this instrument offered composers more choice of sonorities, combining the timbres of assorted instruments to produce the sound of a complete orchestra, with volume controlled by an expression pedal. A succession of French organ composers in the nineteenth century musically blossomed as they composed for the 
Cavaillé-Coll organ. The Belgian César Franck also was such a composer; he taught Vierne, who, in turn, became Duruflé's organ instructor in Paris. Through Vierne and Tournemire, another of his organ teachers, Duruflé was exposed to impressionism, a musical style epitomized by the music of Debussy and Ravel, two composers who, according to Duruflé's own admission, influenced his compositional style. ${ }^{6}$

Impressionists often abandoned classical forms and clear tonal outlines. Their compositional techniques included unresolved seventh and higher tertian chords, ostinato, nonfunctional chord streams, parallelism, added color tones, and innovative timbres such as organists could find on the new, expressive organs. ${ }^{7}$

Duruflé entered the Paris Conservatoire in 1920, studying organ with Tournemire. He once noted that Tournemire never used music when playing services. Instead, he kept a book of chant on the music rack, improvising from the melodies of the appointed liturgies, positioning the Gregorian melodies within chromatic harmonies for the duration of his improvisations. ${ }^{8}$ Tournemire exceeded impressionist boundaries with the degree of dissonance in his compositions.

At the time Duruflé was studying at the Paris Conservatoire, the student body included members of the group known as Les Six. These composers, reacting against chromaticism and some elements of impressionism, found inspiration in the music of earlier centuries. Their instructor, Paul Dukas, praised the music of the eighteenth century and earlier, including the works of Palestrina, Monteverdi, Josquin, and Lassus. ${ }^{9}$

Perhaps because of these early influences, Duruflé chose to write in the forms of earlier centuries, including fugue, rondo, suite, mass, and motet; yet he also wrote as a 
composer of his own time in the two compositions analyzed here. The present study will examine Duruflés Opus 4, an organ work composed in 1930, and his tenth opus, a set of four motets for unaccompanied voices, composed in 1960. 


\section{CHAPTER II ENDNOTES}

1. McCandless, "Cantus Firmus Techniques," 1.

2. Jarjisian, "Influence of Chant," 6.

3. Benjamin van Wye, "Gregorian Influences in French Organ Music before the Motu proprio," Journal of the American Musicological Society 27 no.1 (Spring 1974): 11.

4. William James Dorroh, Jr., "Study of Plainsong," 1.

5. Liber Usualis, ed. the Benedictines of Solesmes (New York: Desclée \& Co., 1956).

6. Ebrecht, Maurice Duruflé, 28-29.

7. Cooksey, "Impressionistic Aspects," 5.

8. Bunn, "A Performer's Study," 104.

9. Frazier, Maurice Duruflé, 42. 
CHAPTER III

Prélude, Adagio, et Choral varié, Opus 4

Duruflé bases Prélude, Adagio, et Choral varié, Op. 4 on the plainchant melody Veni Creator Spiritus. The Chorale varié fulfilled an assignment at the Paris Conservatoire in 1929, while the Prélude and Adagio were added for the 1930 submission to a contest sponsored by Les Amis de l'Orgue. ${ }^{1}$ The final version includes a fast rondo, a slow ternary movement, and a set of four variations. These are connected by transitional passages and conclude with a coda. The cantus firmus is not heard in its entirety until the final section. This discussion of Opus 4 will consider the elements of the chant from which the thematic material is derived before beginning the analysis of the organ work.

The hymn Veni Creator Spiritus is most often ascribed to Robanus, an eighthcentury German theologian, although some hymnologists assign earlier dates. ${ }^{2}$ Its chanting is required by Roman ritual in various ecclesiastical ceremonies, including the Mass of the Feast of Pentecost.

The version of the chant found on pp. 885-886 of the Liber Usualis is shown in Example 1, together with its transcription into modern notation. Four phrases of nearly equal length comprise the melody, forming an arc which begins on the final, reaches its 
apogee a major sixth above in the second phrase, and cadences on the final. The

movement is predominantly conjunct, with leaps confined to the minor third, major third, perfect fourth, and perfect fifth.

Example 1. Veni Creator Spiritus
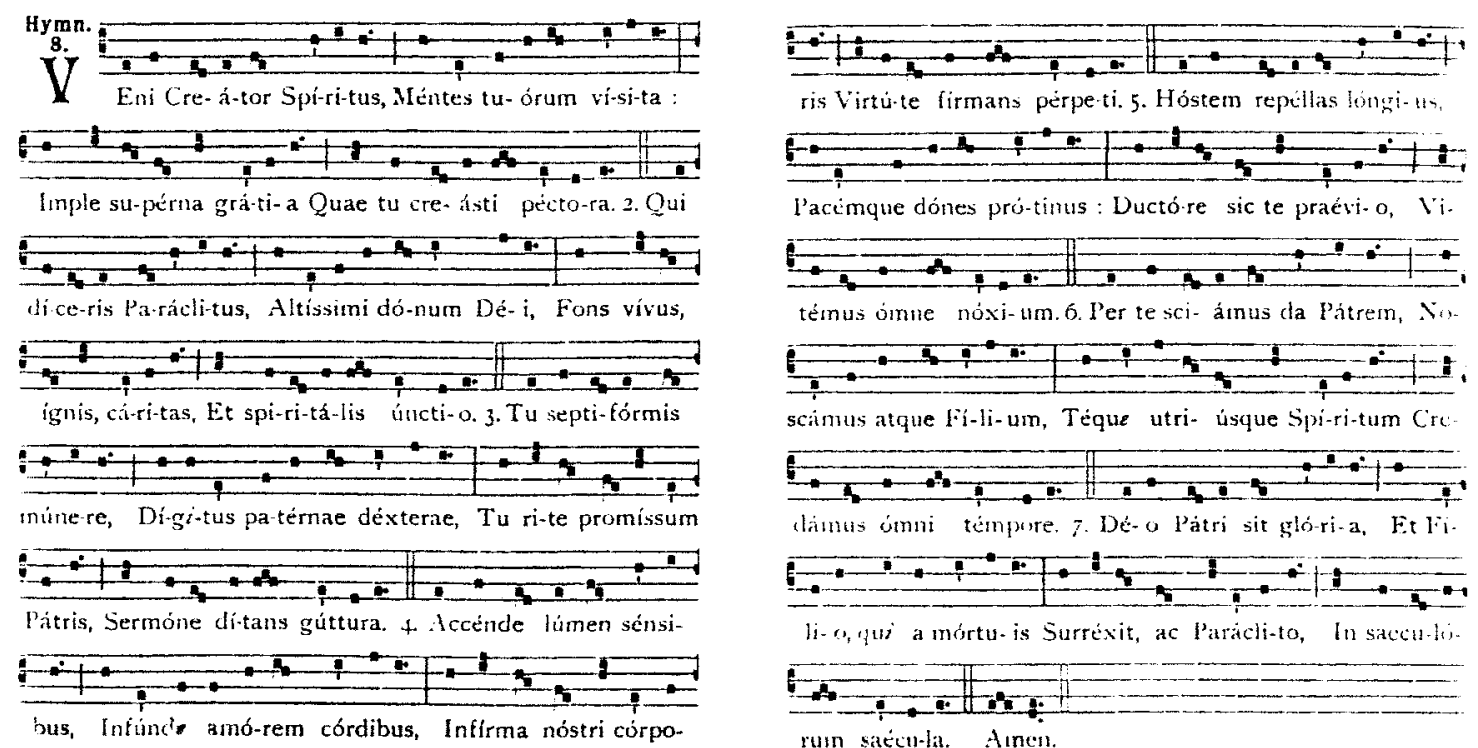

témus óme nóxi-um. 6. Per te sci-ánus da Pátren, So-

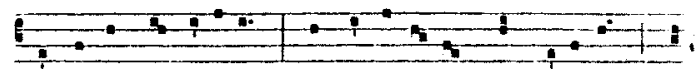
scimus atque Fi-li-um, Téque utri- úsque Spi-ri-tum Cre-
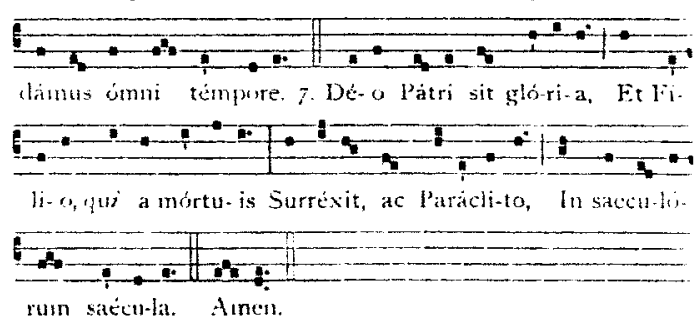

Transcription with notes numbered consecutively

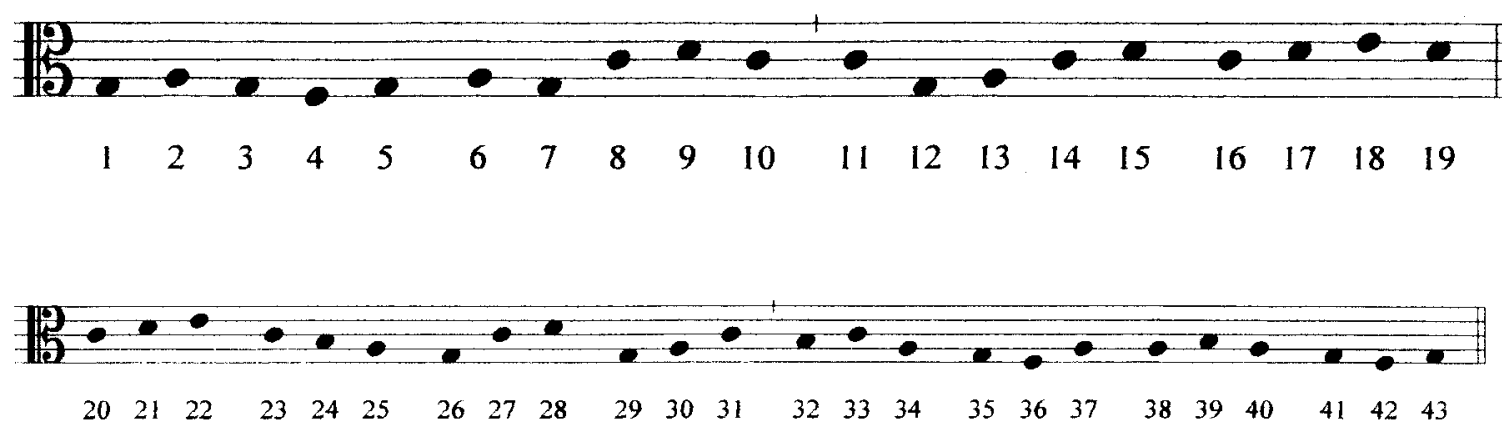


The hymn is in mode VIII, Hypomixolydian. Of the forty-three notes of the hymn, two pitches eclipse the others in importance. Both the final $(\mathrm{G})$ and the reciting tone (C) are found ten times. The modality is maintained by the raised third, the lowered seventh, and the emphasis on both the final and the reciting tone, with plagal identity confirmed by the ambitus (F3-E4) and reciting tone.

The first phrase of the hymn contains two motivic ideas. The first is a neighboring tone gesture; this occurs as both an upper and a lower neighbor. An upward leap to another neighboring tone forms the second motivic idea; the second gesture is significant because Duruflé chooses to develop it in the first movement of Opus 4. These two fragments elide, forming the first phrase of the chant, as shown in Example 2.

Example 2. Motivic gestures forming the first phrase of the chant
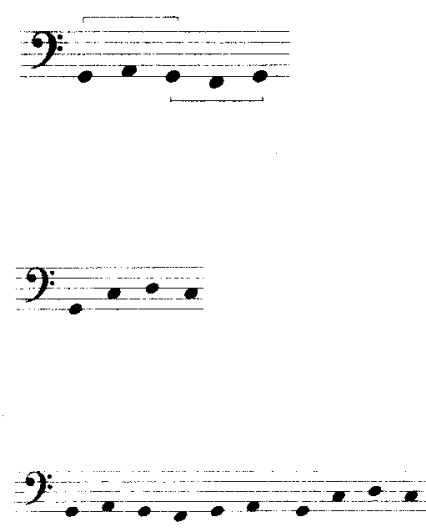

Upper neighbor gesture and lower neighbor gesture

Leap with upper neighbor gesture

The two gestures combined in the first phrase 
Example 3 shows that, although inexact, the two gestures constituting phrase 1 are found in reverse order in phrase 2 , which reaches its pinnacle a whole tone higher than the first phrase.

Example 3. Motivic gestures forming the second phrase of the chant

Inverted gesture and upper neighbor gesture

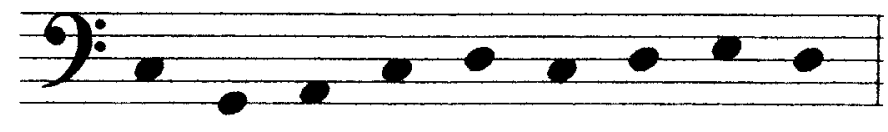

The third phrase begins and ends on the reciting tone, and three times the melody leaps back to it. A set of three consecutive pitches forming a conjunct rising gesture (tones 20-21-22), a set of four consecutive descending pitches forming a conjunct descending gesture (tones 23-24-25-26), and an ending mixing seconds with leaps combine to form phrase three, shown in Example 4.

Example 4. Third phrase of the chant

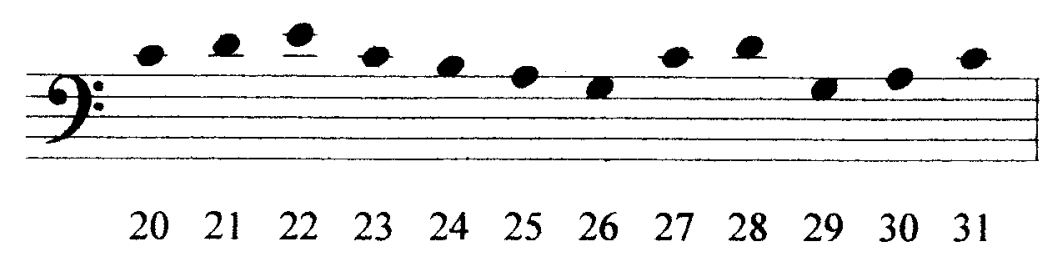

The opening of the fourth phrase of the chant borrows the intervallic configuration of five of the first seven notes of phrase three $(21,22,23,24$, and 25$)$, but two scale degrees lower. The upper and lower neighboring tone gestures, which were elided in 
phrase one, are written without elision in phrase four (note numbers 38-39-40 and 41-42-43). The fourth phrase is shown in Example 5.

Example 5. Fourth phrase of the chant

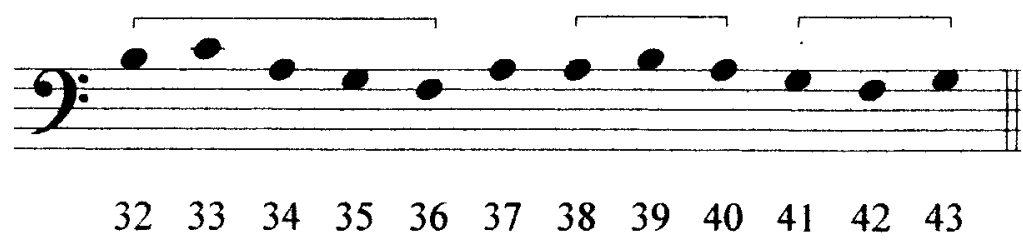

Prélude

The Prélude is constructed in $\mathrm{A} \mathrm{B} \mathrm{A}^{\prime} \mathrm{B}^{\prime} \mathrm{A}^{\prime \prime}$ form, and fragments of the chant are conscripted as generative material throughout each of its sections. The movement takes E Hypomixolydian as its point of departure and return, with digressions to the pitch centers $\mathrm{B} b$ (later enharmonically spelled as $\mathrm{A} \sharp$ ), $\mathrm{F} \#, \mathrm{~A}$, and $\mathrm{Eb}$. The mode or pitch collection is often unclear, blurred by references to fragments of the chant, the modal implications of which are at odds with the prevailing pitch center.

The opening section of Opus 4 begins with fragments of the third phrase of Veni Creator Spiritus, primarily at a pitch level implying transposition of the chant to A, despite the E Hypomixolydian framework. The first pitch of the Prélude is D, accentuating the subtonic of $\mathrm{E}$ and the Mixolydian flavor of the piece. Example 6 
shows the chant and the first two measures of the Prélude, with the fragments employed by Duruflé marked. The neighboring tone idea is prominent and marked as (a) in Example 6; also prominent are permutations of the intervallic cell comprising a perfect fourth surrounding a major or minor third (c).

Example 6. Fragments of the chant with corresponding placement in the Prélude.

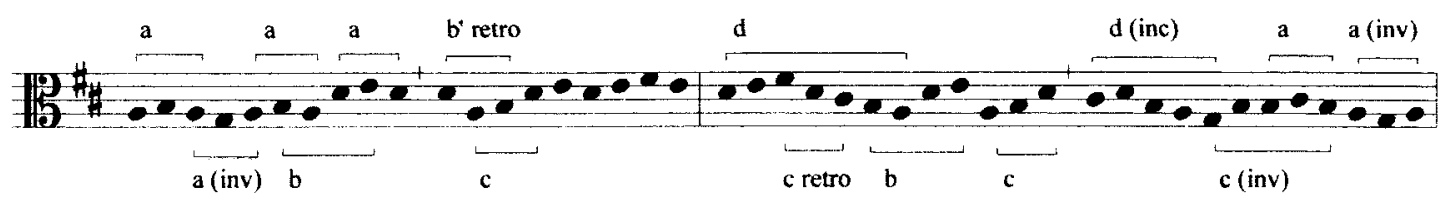

Prélude, mm. 1-2

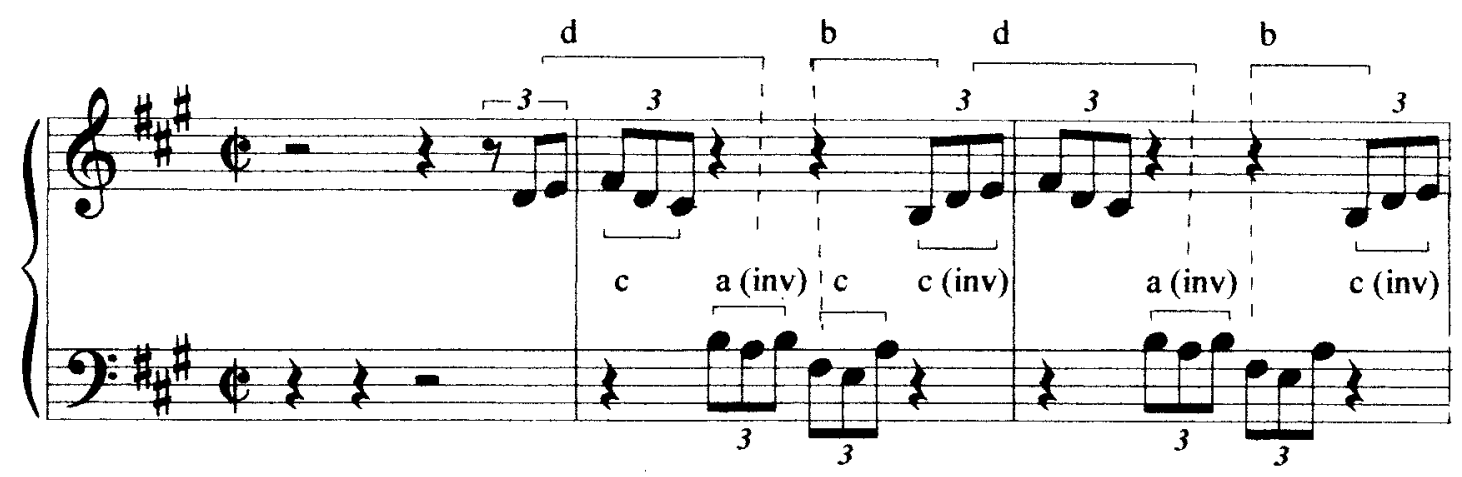


Whereas the A sections of the Prélude feature the third phrase of Veni Creator Spiritus with continuous triplet movement throughout, the B sections expand the second phrase of the cantus firmus, using compositional techniques such as augmentation, diminution, fragmentation, inversion, interval expansion and contraction, ornamentation, and imitation.

The ubiquitous three-note rising motive from the third phrase, seen first in the initial three pitches of the Prélude, is explored in Example 7, which shows its inversions, interval adjustments, and augmentations. The example sketches the motivic information found in the first thirty-four measures, that is, from the beginning until the first reprise of measure 1 in mm. 33.4-35.1.

While triplet eighth notes continually carry the conjunct three-note motive, Duruflé also augments it by using half, whole, and tied notes in every voice; augmented statements of the motive are shown in whole notes in Example 7. (Measure numbers are found above the staff.) One of these augmented statements incorporates planed chords (mm. 17-20). Starting in measure 24, the soprano imitates the bass at a one-measure interval, producing dialogue between rising and falling groups. Although the size of the seconds varies, the substance of the original motive remains intact.

As the texture thins, receding in measure 33 , the incidence of motivic overlap is reduced. The following thirteen measures consist of episodic manual passages with an intermittent $\mathrm{E}$ pedal which lead to a new region of centricity on $\mathrm{B} b$ and a new melodic theme. This $\mathrm{E} / \mathrm{B} b$ juxtaposition introduces the tritone as a prominent organizational element. 
Example 7. Use and location of rising three-note motive in the first thirty-four measures
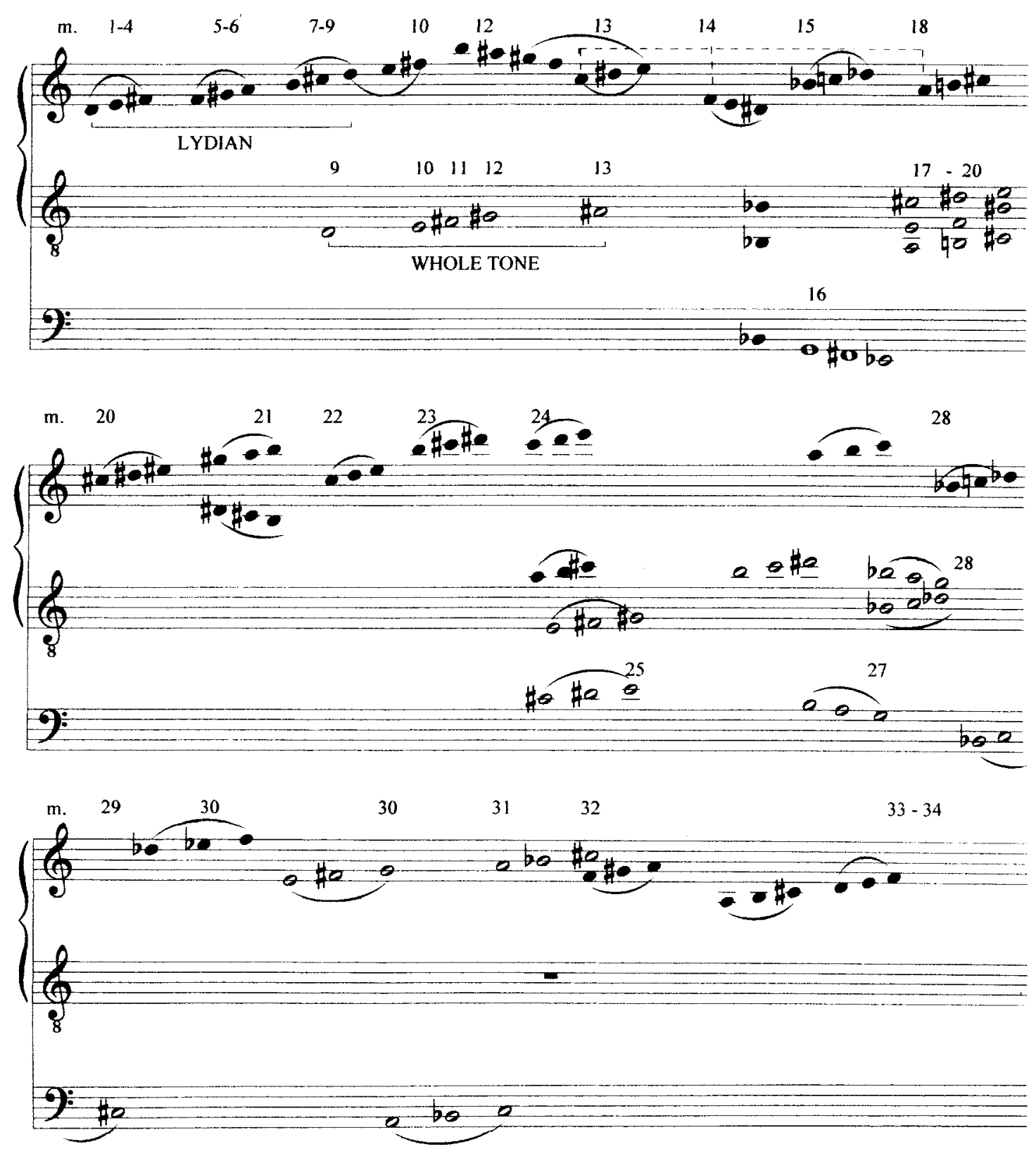

Example 8 sketches the organizational scheme which pairs tritone relationships from the middle of the movement outward. The design directs the pitch center from sections $\mathrm{A}$ and $\mathrm{A}^{\prime}$ to pitch centers a tritone away, followed by a movement of one half 
step. For instance, the section A to section B movement is from $\mathrm{E}$ to $\mathrm{Bb}$ and then to $\mathrm{A}$; movement from section $\mathrm{A}^{\prime}$ to $\mathrm{B}^{\prime}$ is from $\mathrm{A}$ to $\mathrm{E}^{b}$ and then to $\mathrm{E}$. Two additional centers occur which are a tritone from each other: $\mathrm{F} \#$ in section $\mathrm{B}$ and $\mathrm{C}$ in section $\mathrm{B}^{\prime}$.

Example 8. Organizational scheme of the Prélude

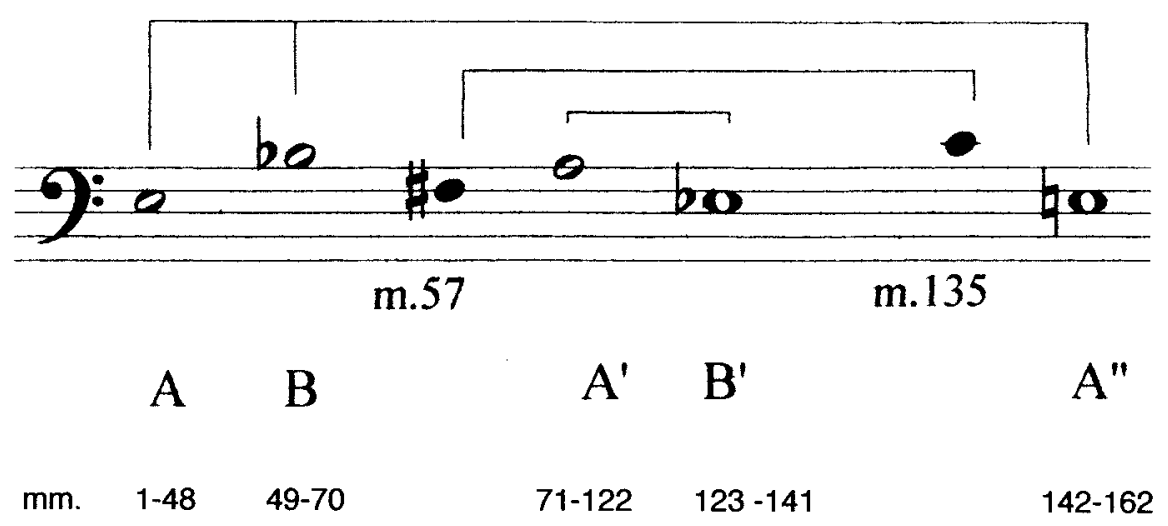

The two pitch centers not defining a structural change, $\mathrm{F} \#$ and $\mathrm{C}$, are equidistant from $\mathrm{A}$ and a tritone apart from each other. The two key centers related to section $\mathrm{B}$ material, $\mathrm{B} b$ and $\mathrm{E} b$, eventually resolve to neighbors one half-step away, $\mathrm{A}$ and $\mathrm{E}$, that is, the principal key centers of the A' and A" sections, respectively; these represent the final and the reciting tone of E Hypomixolydian.

Throughout the movement Duruflé shifts pitch centers abruptly, often to remote 
regions, yet the harmonic scheme retains some traditional features which suggest tonality. The movement from sections $\mathrm{A}$ to $\mathrm{A}^{\prime}$ to $\mathrm{A}^{\prime \prime}$ may be seen as a tonic-subdominant-tonic movement, with a movement from the final to the reciting tone and back.

Often, a chord suggests a pitch center without ultimately resolving to it. While the music is busy developing motives, it presents a succession of quickly shifting, distantly related chords. Movement by tritone happens very quickly, as does movement by third, and chords built on the same roots are inconsistent in quality. Measures 12-18, for example, lead through seventh chords of varying quality rooted on $E, G \#, D \#, A$, and $\mathrm{F} \#$; measures 26-28 journey through E, G, Bb, and Db, returning to E. Such progressions foreshadow the large-scale harmonic scheme which moves by tritones and thirds, from $E$ to $\mathrm{B} b, \mathrm{~F} \#, \mathrm{~A}, \mathrm{E} b, \mathrm{C}$, and returning to $\mathrm{E}$.

The Prélude is a tightly constructed motivic mosaic; yet, at its rapid tempo, it is difficult to hear the quickly passing individual chant quotes or pitch centers. Instead, certain other compositional elements are noticeable, as illustrated in Example 9. 
Example 9. Audibly conspicuous gestures in the Prélude
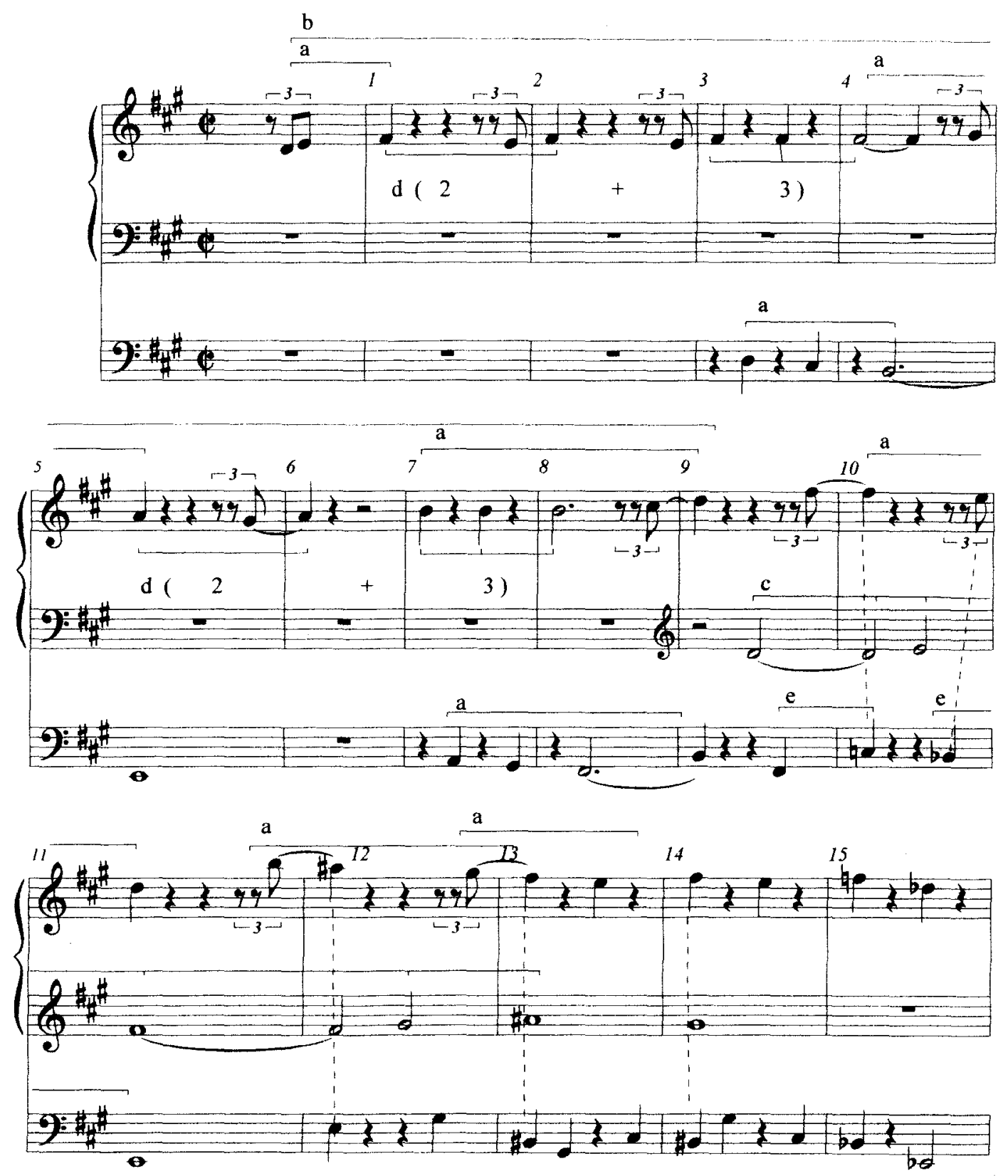
Example 9, continued
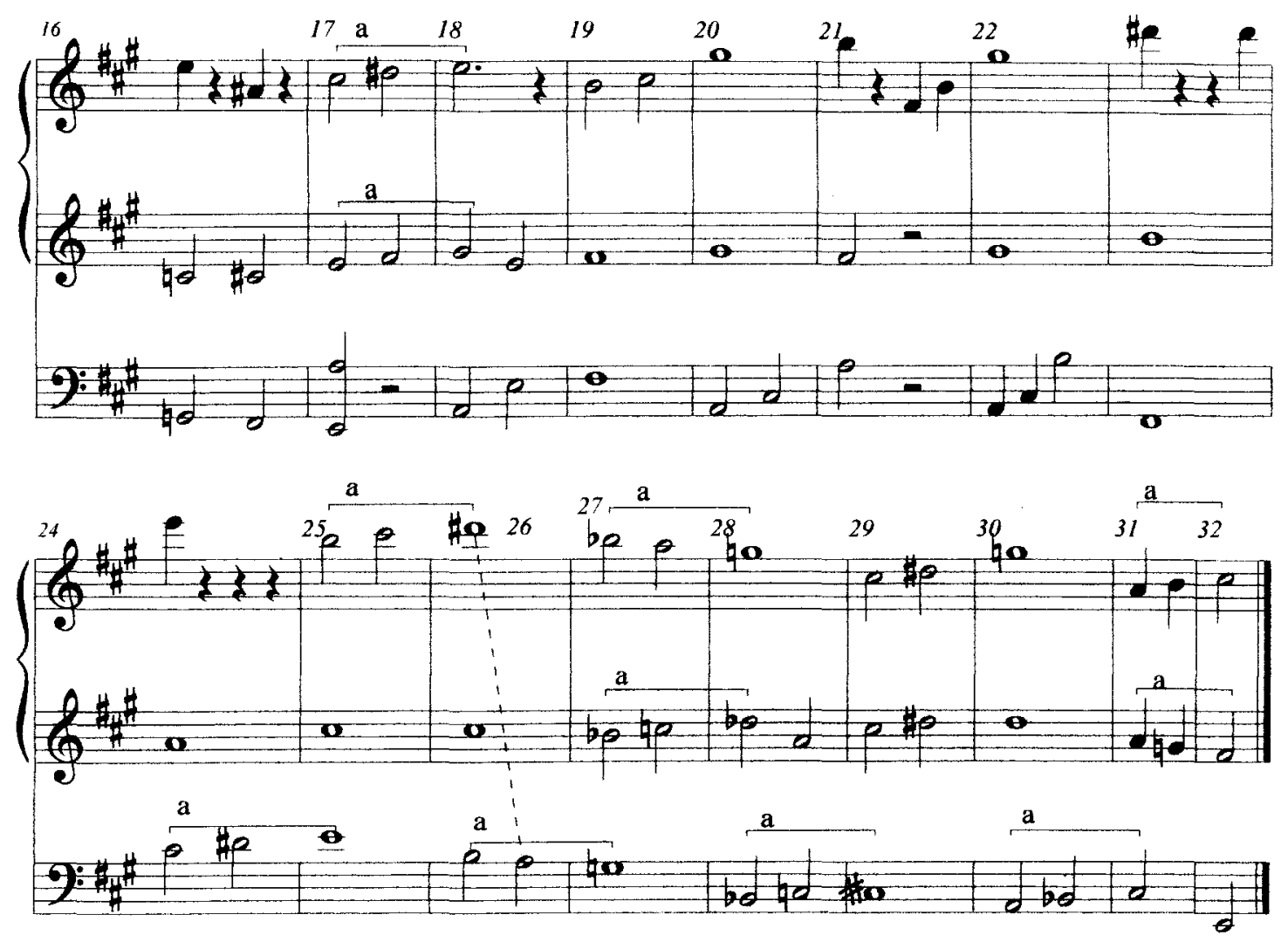

A rising three-note motive (a) is the first thing heard, as the anacrusis to measure 1; this is rhythmically augmented, inverted, traded among voices, and heard in imitation. It pervades mm. 1-32. The Lydian scale on $\mathrm{D}$ is introduced in the rising line of the highest voice of the first ten measures (b). A whole-tone scale fragment in notes of longer duration moves from $\mathrm{D}$ to $\mathrm{A} \#$ in the lower manual staff (c). A rhythmic motive of five emphasized tones, grouped as two followed by three, is embedded in the first four measures (d). This reappears in mm. 5-9 on different pitches. Interplay between $\mathrm{E}$ and F\#, which recurs throughout the work, is noticeable in both the soprano and pedal lines in these early measures. Nontraditional progressions, both arpeggiated and chordal, are 
introduced, and in mm. 9-14, the tritone emerges as an important relationship, both linearly in the pedal part (e) and harmonically as the soprano/bass interval (vertical dashed lines).

The B section of the five-part Prélude begins at measure 47. The melody finds its inspiration in the second-phrase motives of the cantus firmus. The pedals play the first four notes of the phrase, accompanied by the continuation of the arpeggiated triplet configuration of section $\mathrm{A}$. The falling fourth and ascending whole step of the melody are developed in sequence with modified intervals. The transposed chant and examples of its development in mm. 47-52 are shown in Example 10.

Example 10. Development in the Prélude of the second phrase of the chant

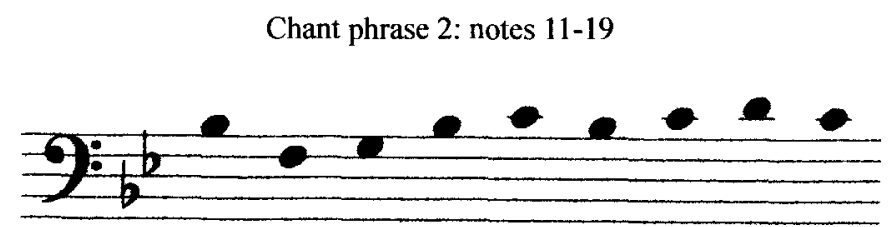

The pedal line of mm. 47-48: measure 47 shares the contour of the first four pitches of phrase 2 ; in m.48, the fourth tone is omitted and the fifth is modified.
m. 47
m. 48

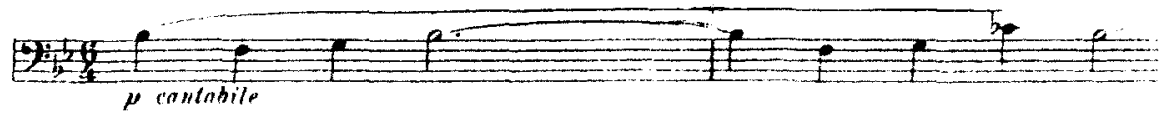

The pedal line of m. 49 shares the contour of the first eight pitches of phrase 2, excluding the fourth chant tone.

m. 49

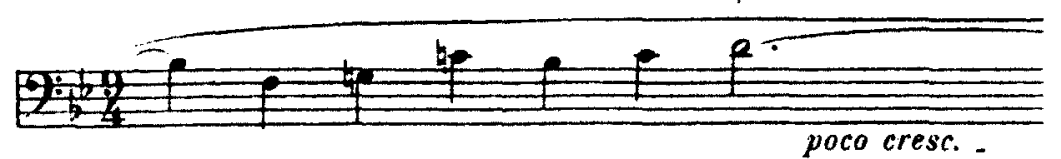




\section{Example 10, continued}

The pedal line of $\mathrm{m} .51$ resembles the phrase 2 contour, with modified intervals and excluding the fourth chant tone.

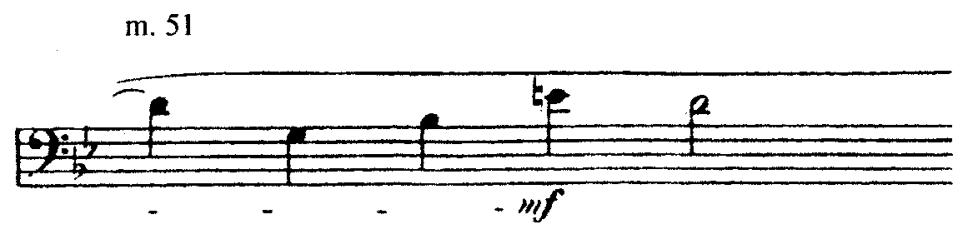

The pedal line of $m .52$ resembles the contour with modified intervals and the omission of the first chant tone.

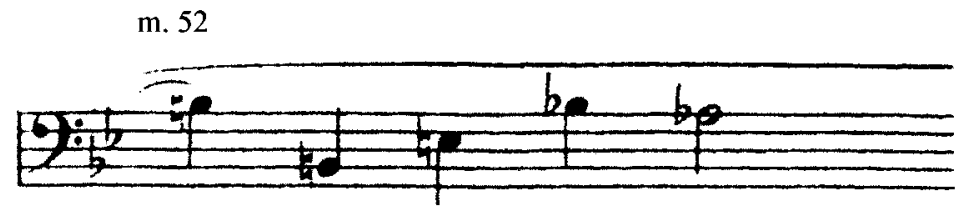

(c) 19 ! Editions bLKAND

D. \& F. 12,016

Tous droits réserves

Paris. France:

pour tous pays.

Embedded in the pedal line of mm. 51-54 is a hybrid octatonic/whole-tone

descending scale, E-D-C\#-B-B-Ab-F\#-E. This is echoed in the soprano line in irregular imitation (Example 11).

Example 11. Octatonic/whole-tone pitch collection in $\mathrm{mm}$. 51.4-54
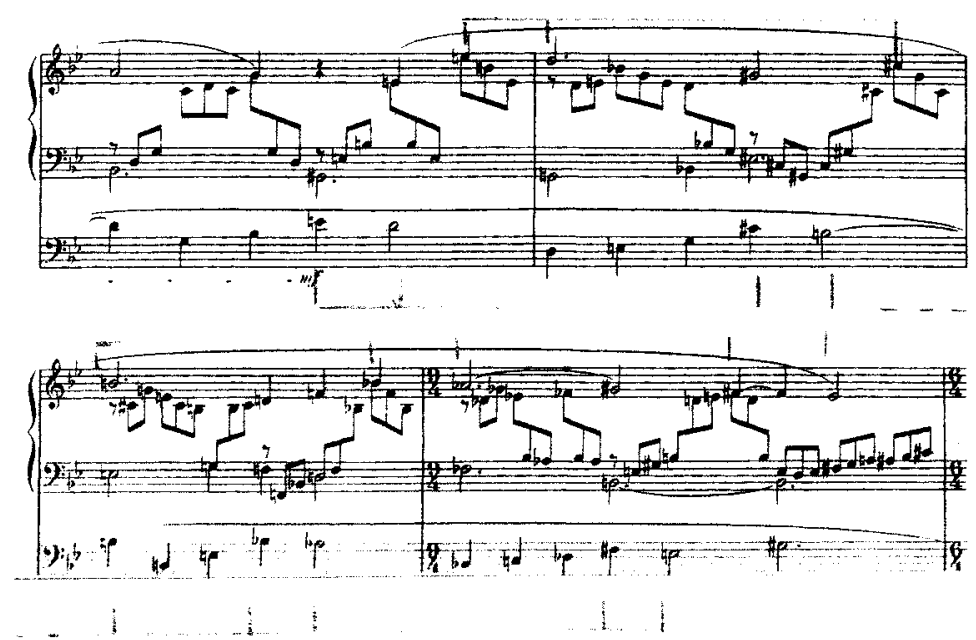
In measures $64-66$, the dyad E-C rises through parallel thirteenths to the dyad a tritone higher, $\mathrm{A} \#-\mathrm{F} \#$. This foreshadows the conclusion of Section $\mathrm{B}$, which ends on a polychord combining $\mathrm{CMm} 7$ and $\mathrm{F} \# \mathrm{Mm} 7$, chords that not only feature the dyads in question but also share $A \#(B b)$. The roots of $C 7$ and $F \# 7$ are a tritone apart and are equidistant from $A$, the pitch center of section $\mathrm{A}^{\prime}$. This polychord also suggests the octatonic collection A\#-C-C\#-D\#-E-F\#-G-A.

The $\mathrm{A}^{\prime}$ section begins in measure 71 with a single pianissimo voice arpeggiating an AmM7 chord. Motivic contours from the third phrase of the chant are interwoven through each voice with chromatic and intervallic changes. Example 12 compares measure 2 and its anacrusis with measures 78.4-79; the latter begins with an inversion of the m.2 motive in its original octave and continues with a statement an octave higher.

Example 12. Comparison of mm. 1.4-2.2 and mm. 78.4-79

mm. 1.4-2.2

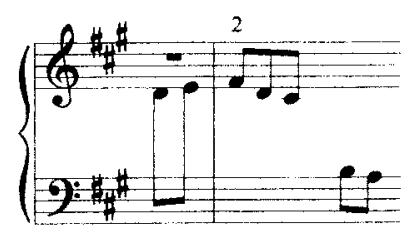

mm. $78.4-79$

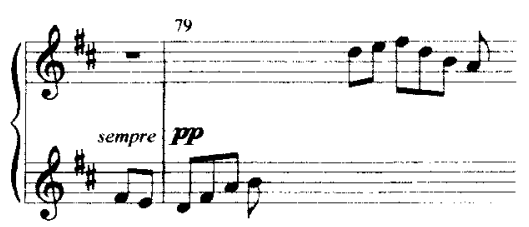

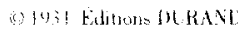

Parto France

D. F. 12,016

Tols druts resertes.

pour tous piats. 
The emphatic G-G-B-B-B and D-D-E-E-E of mm. 71-78 echo the $2+3$ rhythmic idea of mm. 1-8. Example 13 compares the two passages.

Example 13. Comparison of the $2+3$ pattern in $\mathrm{mm} .1-8$ and $\mathrm{mm}$. $71-78$ (right hand)

mm. 1-8

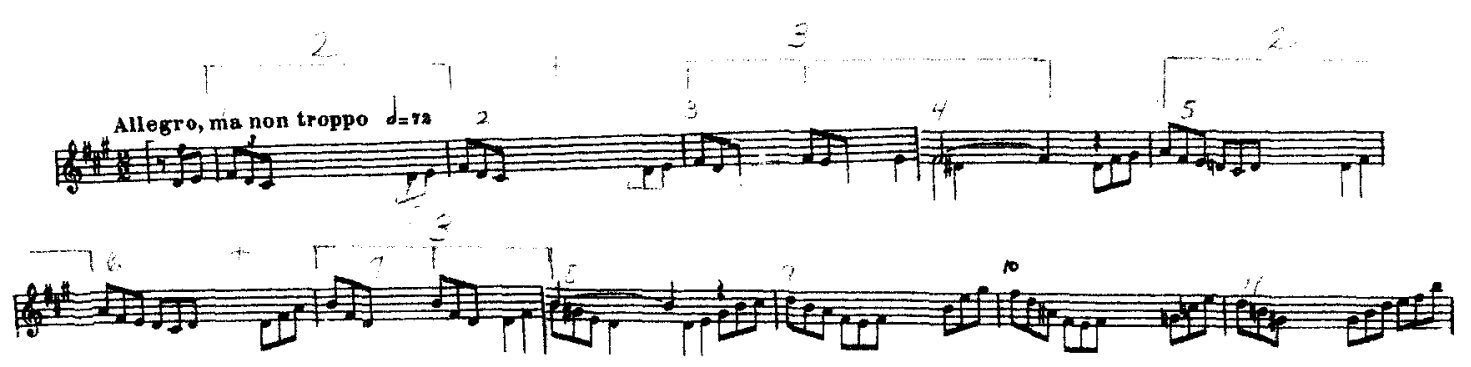

mm. $71-78$
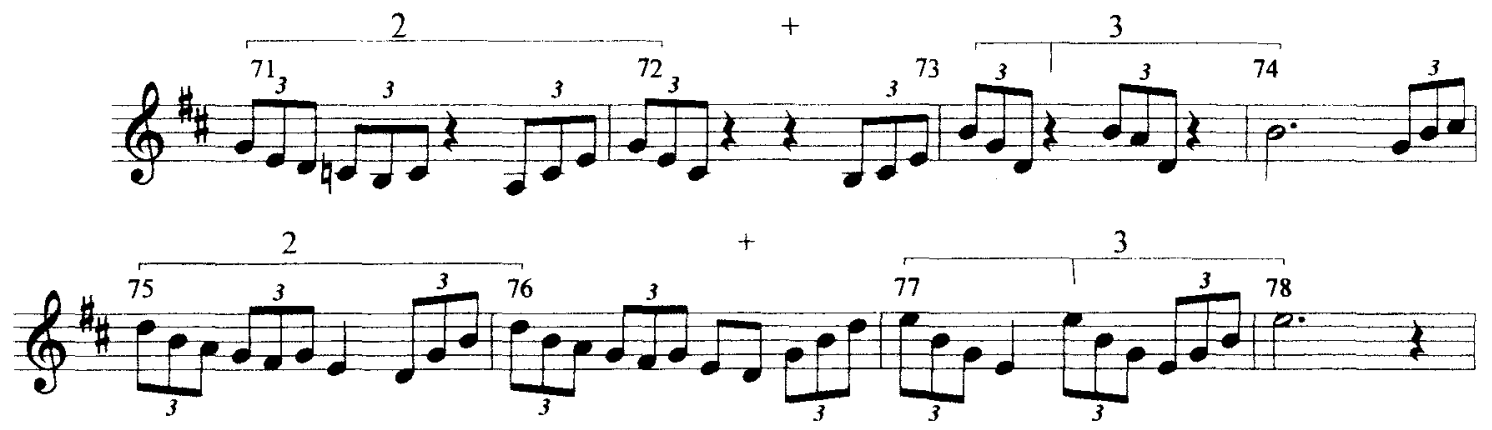
Like the A section, A' presents a fast, tonally fluid area. The first three or first six pitches of the third chant phrase anchor this section, often sounding in half or whole notes.

In the measures leading up to $\mathrm{m} .123$ the harmonic texture hints at $\mathrm{B}$. The D\# of this B harmony in $\mathrm{m} .122$ is enharmonically reinterpreted as $\mathrm{Eb}$ in $\mathrm{m} .123$; this is the focus of the new centric region in which section $\mathrm{B}^{\prime}$ begins, a tritone from the most recent centric domain of A and a perfect fifth below the center of the B section. The melody, derived from the second phrase of the chant, is found in the alto line, now transposed to $\mathrm{E} b$ and supported by double organ pedal. The accompaniment and imitating voice remain as in the $\mathrm{B}$ section.

The new $\mathrm{Eb}$ pitch center is juxtaposed with a continuing influence of the $\mathrm{A}$ Mixolydian scale. The $\mathrm{Eb}$ and $\mathrm{A}$ are included in the pitch collection, creating a wholetone/octatonic hybrid. The hybrid is used in an ascending scalar passage in $\mathrm{m} .133$, and in the upper-voice descending line of mm. 129-132, ranging from A5 to A4. Both are shown in Example 14. 
Example 14. Hybrid whole tone/octatonic collection

mm. $130-132$

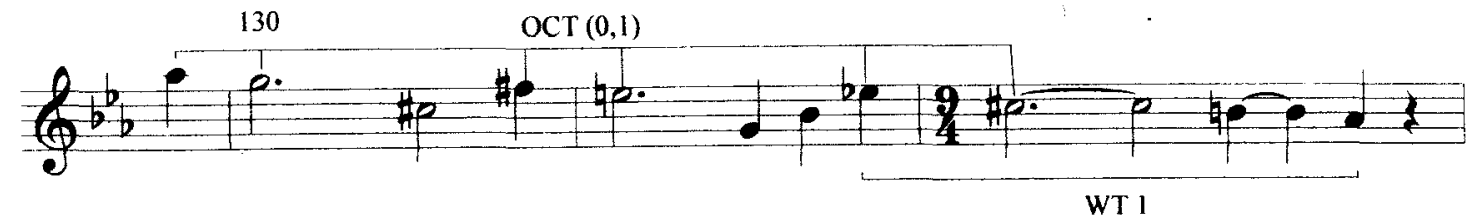

m. 133

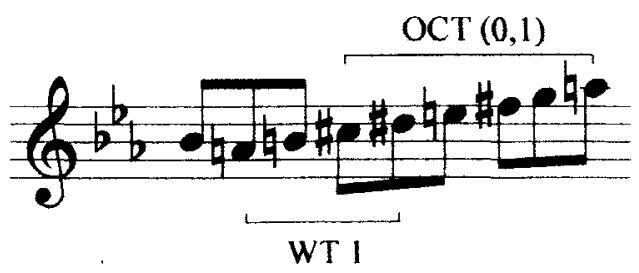

(c) 19: Edition [lLRAND

Puris, France

D. \& F. 12,016

Tous droits resenes

pour tous pays.

The $\mathrm{Eb} / \mathrm{A}$ tritone juxtaposition continues in measures $133-134$, where the $\mathrm{Eb}$

chords are briefly interrupted by an A major triad. A surprising cadential arrival on C

major follows in measure 135; this is prepared by the expansion of the dyad Db-F to C-G.

$\mathrm{A}^{\prime \prime}$ makes a false start in measure 137 , where the motive of $\mathrm{m} .1$ begins in triplets

over an E pedal point and a left-hand cluster. The E center is clear, but the modality is ambiguous owing to the omission of $\mathrm{G}$ or $\mathrm{G} \#$ from the pitch collection. After two measures, C major returns briefly; then Section A" continues in measure 142 with a return to the original $\mathrm{E}$ pitch center, a textural change, and an abridgment of the reiterated material. 
At measure 142, a series of whole and half note chords over an E pedal point accompanies the soprano triplet figuration. The series begins with $\mathrm{B}$ minor in root position, changing to chords which vary in root and quality while retaining $B$ as the lowest chord member. The pairing of $\mathrm{E}$ with $\mathrm{B}$ continues with the double pedal $\mathrm{E}-\mathrm{B}$ in mm. 147-150 and the descending scalar passages beginning on $B$ and ending on $E$ in measures 152-154.

Measures 153-156 recall the neighboring-tone gesture from the chant, played in triplets and using both the minor second E-F and the major second E-F\#. The ending chord of the movement contains only E and B.

Bridge

The bridge connecting the Prélude to the Adagio is labeled Lento, quasi recitativo. The third note, $\mathrm{D}$, is the highest in the bridge and is also emphasized in the final measure. The passage is heavy with tritones, ending finally in a $G$ minor chord which is tied to the first chord of the Adagio.

The composer first writes $G$ enharmonically ( $F$ double sharp) in the fifth measure of the recitative. Although the pitch is not completely absent, it is not prominent; it is, however, centric in the sense that it serves as the axis of symmetry. The two chords in the second and third measures of the bridge are $\mathrm{F}$ minor and $\mathrm{A}$ minor, equidistant from $\mathrm{G}$ minor. The six-note motive which begins the bridge is transposed in the seventh measure to $\mathrm{G}-\mathrm{A}-\mathrm{B} b-\mathrm{G} b-\mathrm{F}-\mathrm{E} ; \mathrm{G}$ is equidistant from its highest and lowest pitches. Both the highest and lowest pitches of the next group of six are a tritone from $\mathrm{G}$, which is thus likewise centered between the two. 
The final measure of the bridge includes the composer's detailed instructions for adding stops until the fortissimo on D is reached. At that point, the composer prescribes the orderly release of stops to effect the dramatic fading of volume and to prepare for the Adagio.

\section{Adagio}

If the bridge is considered a recitative, then the Adagio may be compared to a $d a$ capo aria with cadenza. The first twenty-nine measures comprise section A, which, in the first two measures, quotes the first hymn phrase with only a single chromatic change.

The pitch center of the principal section of the Adagio is G, confirmed by the pitches used, the bass line, the harmony, and the linear motion which both rises and descends to G. Similarly, the bass line of the eight-measure first phrase is characterized by the descending half step and ascending whole step surrounding the final, indicative of the Phrygian collection. The frequency of $\mathrm{G}$ minor and $\mathrm{Ab}$ major chords also implies $\mathrm{G}$ Phrygian.

Duruflé continues the practice of threading the music with chant. Here the cantus firmus is set in $\mathrm{Bb}$ Mixolydian, a collection with the same pitch content as the G Phrygian collection that pervades the harmony. Example 15 shows variants of the chant motives in mm. 1-12. These measures reference the first phrase of the melody. In each, a leap of a fourth or fifth is followed by movement to an upper neighbor and back. 
Example 15. Contour of the first phrase of Veni creator throughout mm. 7-12

Mm. 1-3 of the Adagio, highest voice

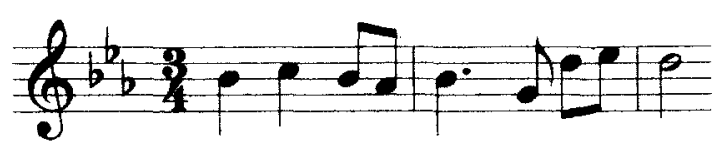

Mm. 9-11, highest voice

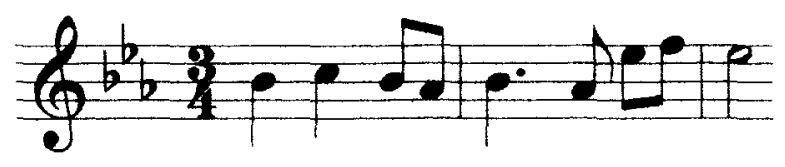

Mm. 1-3, alto line

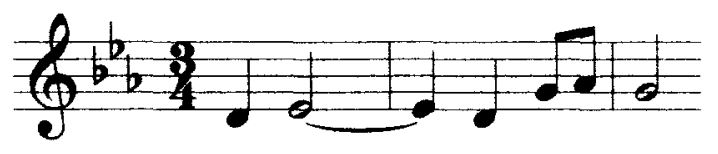

Mm. 7-12, tenor line

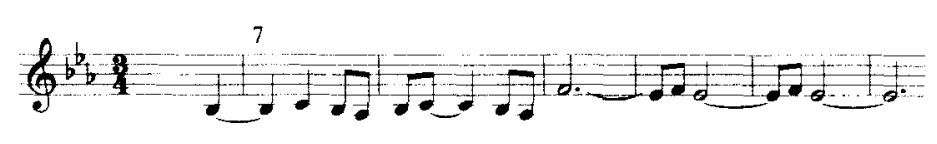


A brief stretto between the soprano and tenor (mm. 24-25) prepares the approach to the final cadence of the A section (m. 29). This is shown in Example 16.

Example 16. Stretto in the soprano and tenor

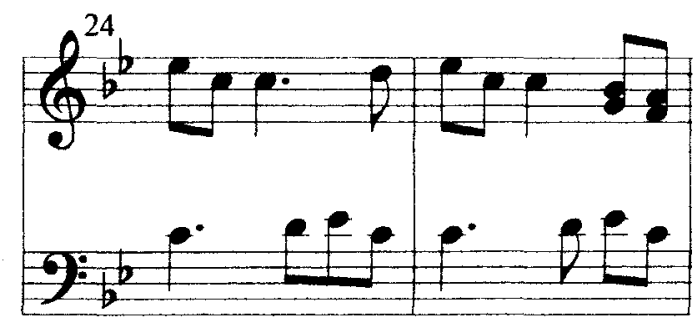

(6) 193 Editions [ULRAND

Paris. France

D. \& F. 12,016

Tous droits réserves pour tous pars.

The B section of the Adagio begins in m. 30, following a one-measure link. As Example 17 shows, Duruflé's pedal line in mm. 32-39 retains the same contour as the chant, while transforming its modal basis to the octatonic collection E-[F]-G-Ab-B b-B C-D. These alterations allow Duruflé to outline a $\mathrm{G}$ major triad shortly before leaving the G-centric region: the pedal line of mm. $32-39$ begins on $B$ and ends on D, while a prolonged $\mathrm{G}$ supplies the triadic root. 
Example 17. The third phrase of the chant, transposed to F\# and compared with the pedal line of mm. 32-39

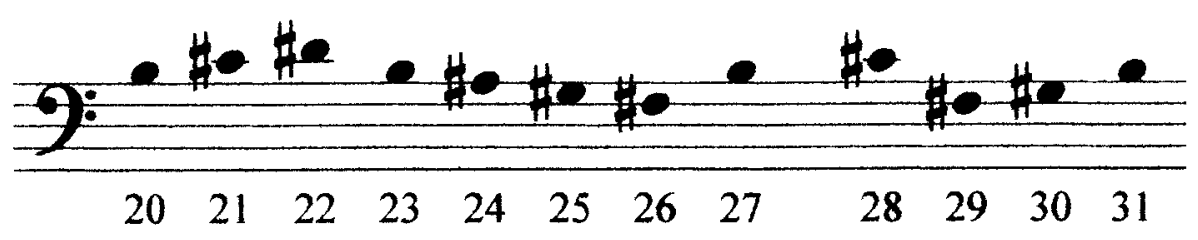

Pedal line of $\mathrm{mm} .32-39$

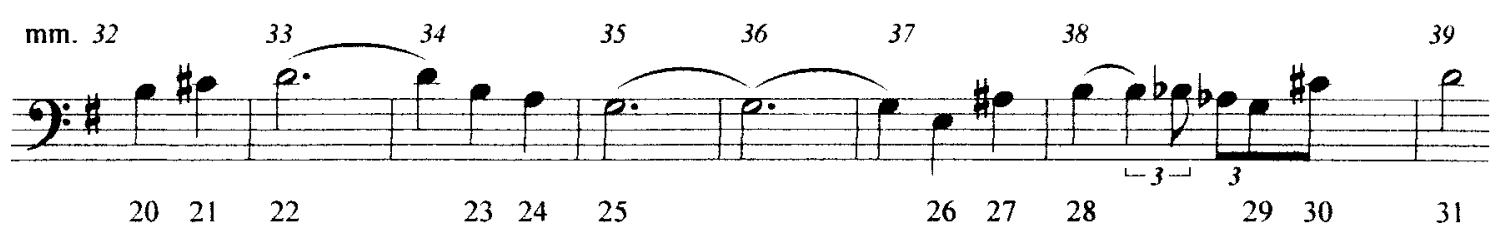

O) $19: 1$ Editions DLRAND

D. \& F. 12,016

Tous droits résenés

Pars. France

pour tous pays.

The top line of measures 40-41 twice adopts the contour of the first five notes of the third phrase of the chant. The chant is compared to these measures in Example 18. 
Example 18. Comparison of the first five notes of the third phrase of the chant (transposed to A) with the top voice of the manuals mm. 40-41
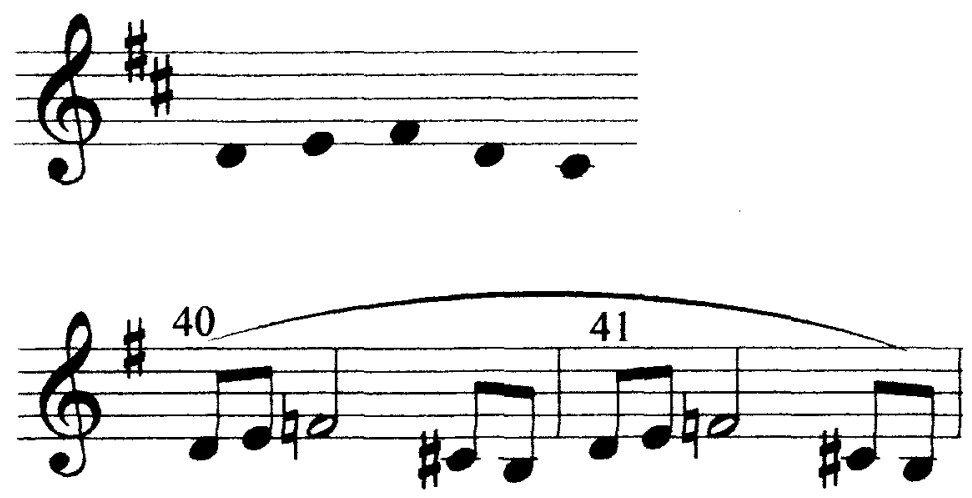

O) 91 Edition [)(RAND)

Paris. France

D. \& F. 12,016

Tous drous résernés pour lous pays.

Parallel fifths, fourths, thirds, and triads congruent with impressionistic technique abound in the Adagio. Parallel first and second inversions are found in mm. 7-8, and parallel fifths are notable in mm. 40-45. During a developmental passage in the Adagio, the double pedal line in the organ plays parallel fifths, leaping by minor thirds through measures $40-45$, to a cadence on $\mathrm{B} b$ minor. Example 19 shows some examples of parallel fifths and triads in the Adagio 
Example 19. Parallel fifths in the Adagio

Parallel fifths in measures 2-4

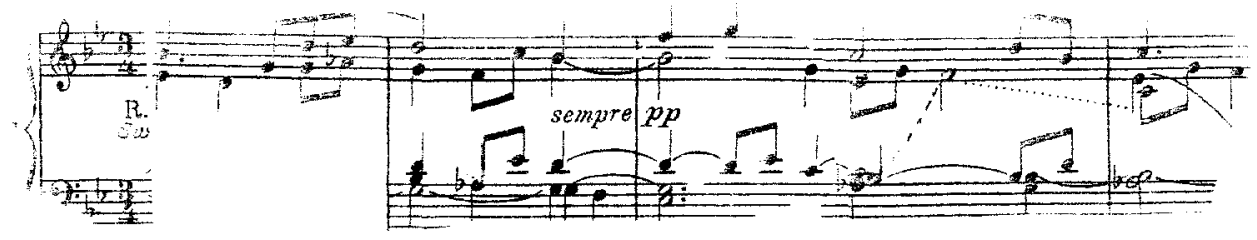

Parallel first- and second-inversion triads in measures $7-8$

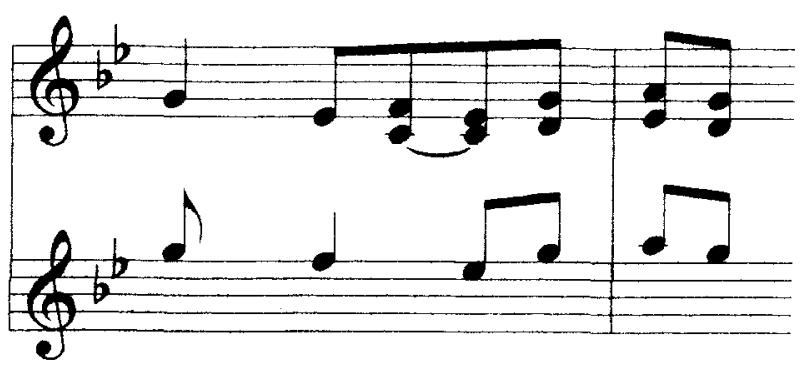

Parallel fifths in the pedals in measures 40-41

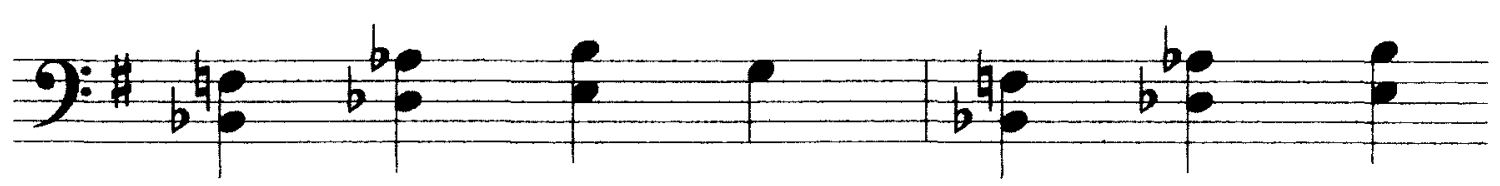

Parallel fifths in the pedals in measures 44-45

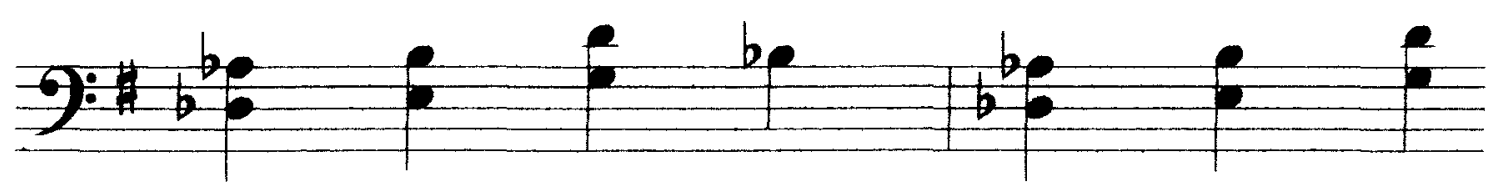


In $\mathrm{m} .29$, a rise of a third to an accented $\mathrm{B} b$ is repeated, then followed by three iterations of a $\mathrm{G}$ major chord with the third in the top voice, each chord falling on the first beat of three contiguous measures. This creates a $2+3$ rhythmic gesture similar to that of mm. 1-4 in the Prélude. As in the Prélude, the first two emphasized notes of the $2+3$ idea are approached by a third from below. The two gestures, the first from the Adagio and the second from the Prélude, are shown in Example 20.

Example 20. Comparison of the Adagio, mm. 30-33, with the Prélude, mm. 1-4.

Adagio, mm. 30-33

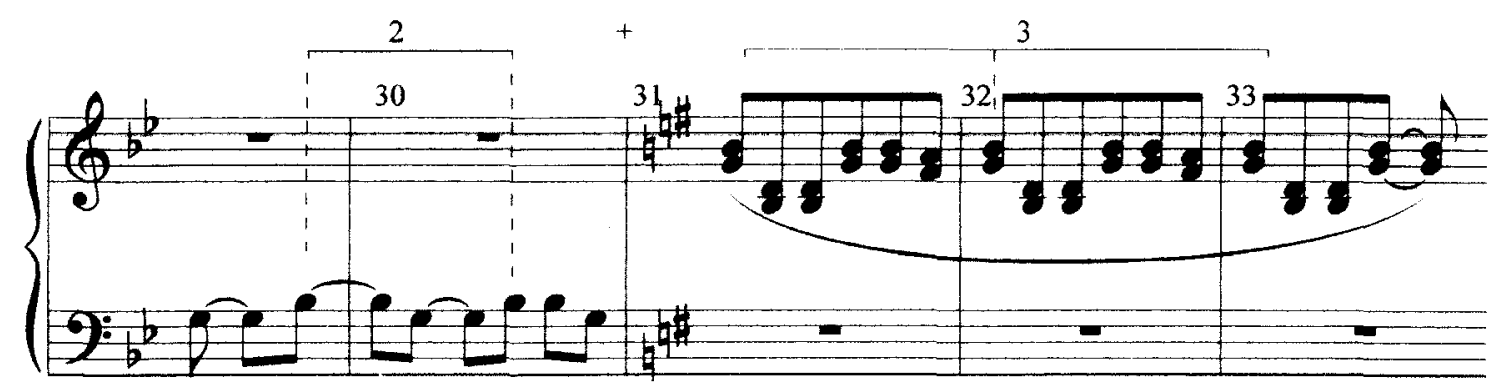

Prélude, mm. 1-4

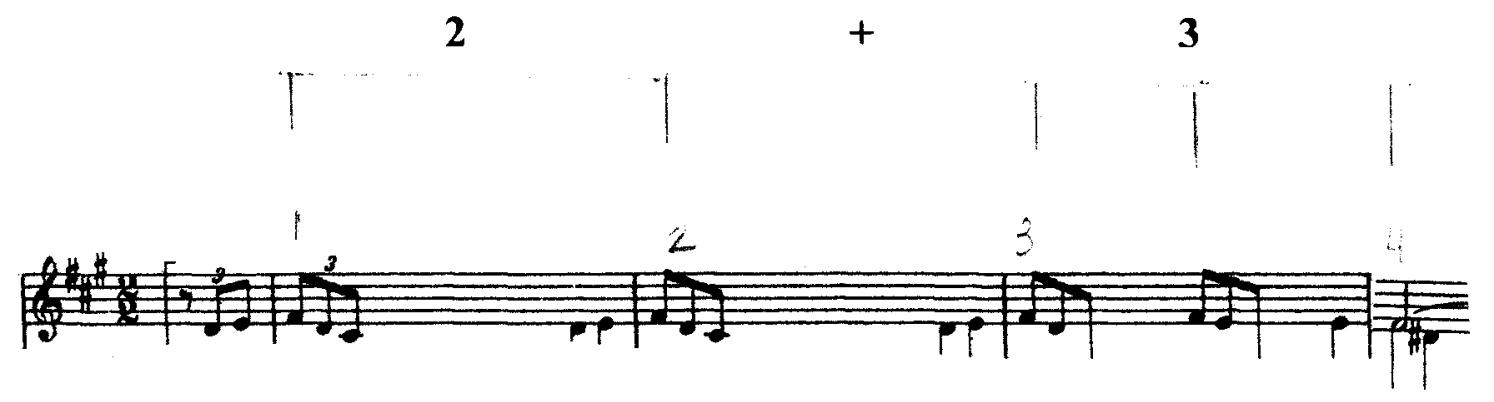


The first phrase of the B section is extended in mm. 34-39, where the right hand gesture of mm. 31-33 continues in fragmentary, interrupted form over a tritone double pedal consisting of $\mathrm{G}$ in the bass and $\mathrm{C} \#$ in the tenor. The consequent phrase, mm. 40-43, opens with the same stepwise rising third as its prototype from the Prélude. Twice the conjunct motive rises to $F$, followed by a motive similar to that of mm. $31-33$ of the Adagio but lacking the final downbeat of $\mathrm{m}$. 33. The characteristic $2+3$ rhythm is thus truncated. The $\mathrm{F}^{\natural}$, the apogee of the rising pitches in measure 40 , foreshadows the $\mathrm{B} b$ chord in mm. 42-43. Example 21 compares mm. 40-43 of the Adagio with mm. 5-8 of the Prélude.

Example 21. Development of the $2+3$ pattern in mm. $40-43$ of the Adagio, compared with $\mathrm{mm} 5-8$ of the Prélude

Prélude, mm. 5-8

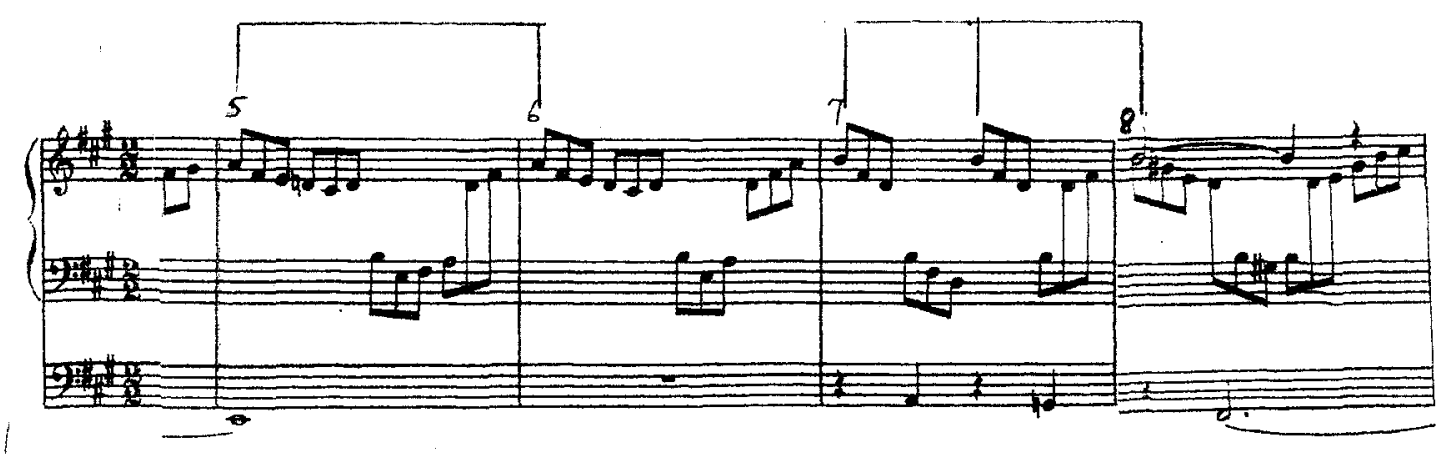


Example 21, continued

Adagio, mm. 40-43

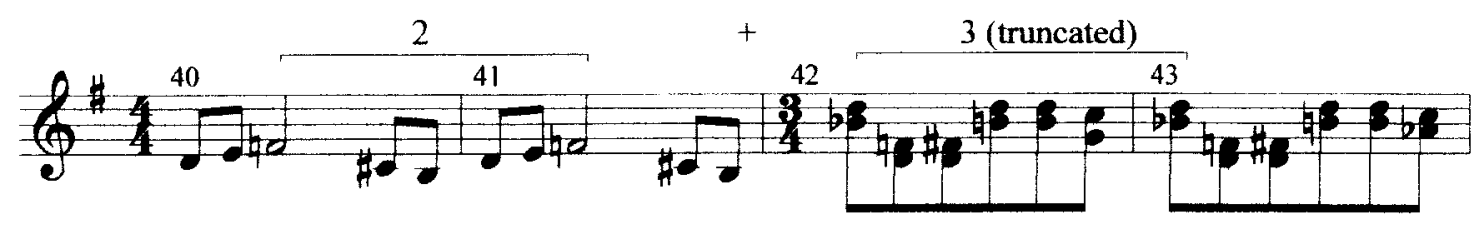

(1) 1911 Editions (1CRAND

Paris. France.

D. \& F, 12,016

Tous droits résenés pour tous pays.

Like the Prélude, the Adagio progresses by thirds from one centric region to the next. Although the Phrygian mode is abandoned in the B section, the G center remains in effect until it is replaced by $\mathrm{Bb}$ in m. 40 . Section $\mathrm{A}^{\prime},(\mathrm{mm} .53-78)$ is centered on $\mathrm{Db} / \mathrm{C}$; the harmonization of the melody is similar to that of Section A.

The cadenza begins in m. 79, continuing until the Molto rit. in $\mathrm{m} .107$ (mm. 249-276 if measures are counted from the beginning of the Prélude). Climactic buildup (beginning in $\mathrm{m} .82$ [251] and culminating in $\mathrm{mm} .96-99$ [265-268]) is accomplished through thickening the texture, increasing the volume by adding stops, accelerating the tempo by specifying animando and animato, and increasing the rhythmic complexity.

J.S. McIntosh refers to the cadenza as

an extended, rhapsodic transition whose complex figurations, increasing speed and tremendous volume-containing as it does the most powerful climax in the work, apart from the endingare intended to produce a contrast between the Adagio and the Choral which follows. ${ }^{3}$ 
In his dissertation, Driscoll identifies a Golden Section by timing Duruflé's recorded 1963 performance, which included additional chant verses sung by a choir in the third movement. The climax of Opus 4, starting in measure 265, appears between time indices 12:56 and 13:06. As a percentage of the total performance time, "the climax is between $61.3 \%$ and $62.1 \%$--almost exactly centered on the 'Golden Mean' point of the piece, $61.8 \% . "{ }^{\prime 4}$ The author of the current study compared this with the proportion revealed by counting measures (excluding the sung verses of the chant, which are not in the score), and discovered that $61.8 \%$ (the Golden Mean) of the total measures of Opus 4 occurs in measure 262, the measure preceding the Animato (measure 94 of the Adagio). This is separated by only three measures from Driscoll's placement of the Golden Mean according to his analysis of the performance time.

\section{Choral varié}

The final movement presents the Gregorian melody in its entirety, both in added human voices and in Duruflé's music. Traditional sacred music practice in France combined singing with solo organ. Much of the body of extant eighteenth and nineteenthcentury French organ music consists of sets of "versets" intended to be played in alternation with sung text.

Although the score does not indicate the singing of the chant, Durufle's own recording of this movement included it, and three more recent recordings follow his 
example, although not necessarily using the same structure. Duruflé's recording and the extensive use of alternatim in France and Italy validate the performance practice. ${ }^{5}$ Duruflé arranged the vocal and instrumental sections in this order: Theme; first verse of the chant; Variation I; second verse of the chant; Variation II; third verse of the chant; Variation III; seventh verse and Amen of the chant; Variation IV.

The addition of chanting reminds the hearer that the purpose of the composition is to draw attention to the Pentecost story, and it serves as well to balance the piece structurally. If the free flowing chant verses are assigned thirteen measures each, the four verses would add fifty-two measures; with the addition of the Amen, the sum becomes 172, a length comparable to that of the Prélude. Finally, chanting molds the third movement into a liturgical piece which can be inserted into a worship service.

Duruflé begins the initial section by setting Veni Creator as a four-phrase, fivevoice chorale with the chant in the top voice. The chant is harmonized in A major over a descending Mixolydian scale from E3 to E2 in the pedal line. The rich tertian chords form a traditional-sounding hymn setting. Every phrase ends with a functional tonal cadence in A, although the final cadence is a half cadence. The modality manifests itself in the initial and final pitches on E, in the Mixolydian descent from E3 to E2, and in the selection of $\mathrm{A}$ as a melodic reciting tone.

Four variations follow the chorale, each employing all four phrases of the melody. Writing in common time until the final variation, which is in $2 / 2$, Duruflé establishes a sense of meter by situating the initial and final notes of each phrase on the ictus. Each variation liberally employs triplets, and, except in the third, juxtaposes them 
with duplets to create 3:2 cross rhythms. As in the Adagio, Duruflé sets the chant as a metric melody, with $\perp \int J$ as his characteristic opening rhythm.

\section{$\underline{\text { Variation I }}$}

In the first variation, the cantus firmus is transferred to the pedal line. As in the preceding chorale, phrases are separated by rests.

The mode is emphasized by an embedded E Mixolydian scale in the lower voices of the opening of the variation. As shown in Example 22, the tenor descends from the initial D-E dyad, joining with the chant statement in the pedal in m. 3 to complete the descending scale. The tenor voice then fades into the fabric of the triplum-like left-hand manual.

Example 22. Descending Mixolydian scale embedded in the tenor and bass of the opening measures of the first variation (mm. 15-17.2 of the movement)

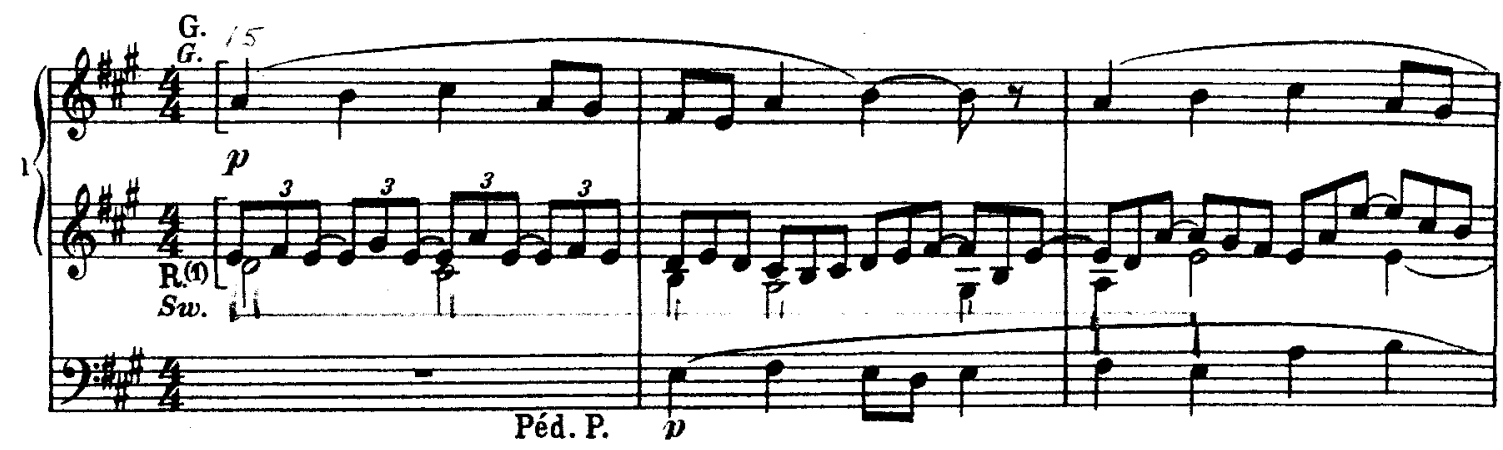

$31 \%=1$ Fdition (URAND)

D. \& F. 12,016 
The alto voice plays triplets continuously. Frequent tying from the end of one triplet figure to the beginning of the next de-emphasizes the beat in this voice, allowing the soprano, which usually moves on the beat, to achieve greater prominence.

Example 23 shows the soprano chant phrases paired with the pedal line. The upper voice states the third chant phrase on A, repeats it, then develops the first and third phrases. Duruflé instructs organists to employ the Nasard $2^{2 / 3}$ on the Great and an $8^{\prime}$ Cromorne in the pedal. The harmonics of the former and the nasal sound of the latter further emphasize the duet.

Example 23. Soprano/pedal duet in Variation I
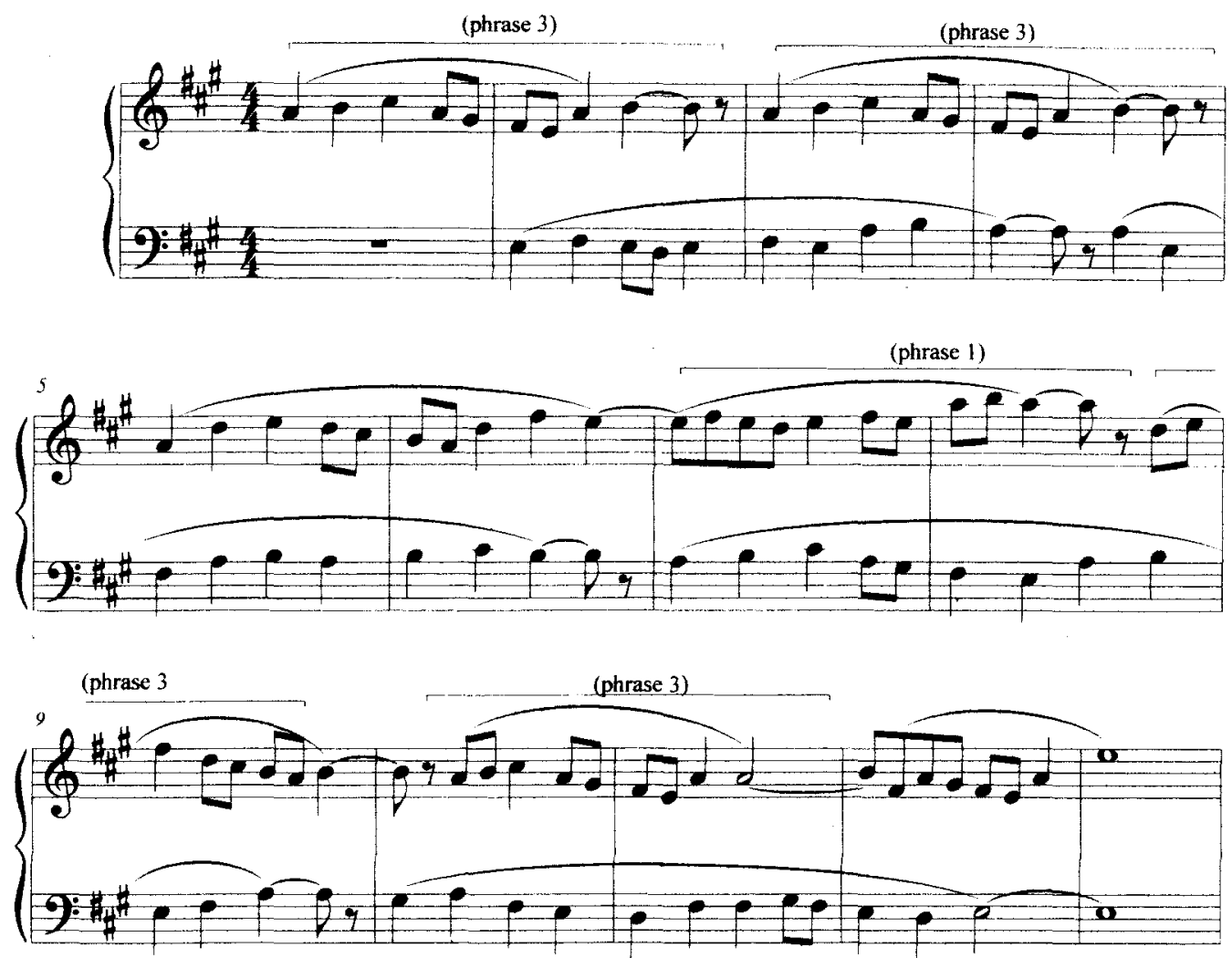

G193 Editions ULAND Paris. France

D. \& F. 12,016

Tous drous résenes pour tous pays. 
Variation I is centered on E, with Hypomixolydian being the principal mode. G naturals in the fourth and fifth measures alter the modal flavor briefly to Dorian. An open fifth on E provides the closing chord.

\section{Variation II}

In the pianissimo second variation, the first note of each triplet doubles as the melodic line, receiving the full beat, except on three occasions when the melody briefly falls into the triplet form. (Duruflé highlights the notes of the cantus firmus with upward stems in the score.) The use of the 2' piccolo stop in the left hand weaves it above and below the upper line and lends a music-box sound to the fast, closely-voiced treble, an effect further enhanced by the absence of the pedal in this variation. As a result of the interweaving the chorale melody is embedded, surrounded by pitches above and below it. Example 24 shows the actual sound of the first two measures of Variation II. 
Example 24: The realized sound of the opening of Variation II, due to the use of the 2' stop in the left hand registration.

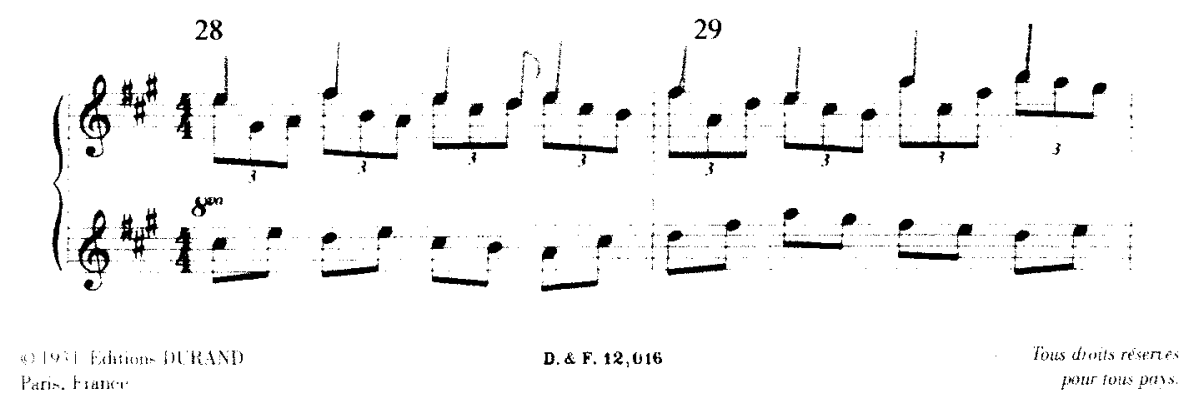

The two-against-three writing propels the sense of tempo, although no acceleration is specified in the score. The cantus firmus is centered on E, and the variation ends on an incomplete $\mathrm{E}$ major triad.

\section{$\underline{\text { Variation III }}$}

A canon appears in the third variation between the top voice and the pedal with registration for the latter specified as a $4^{\prime}$ flute. Although the dux is written in the top voice, the $4^{\prime}$ registration of the comes causes it to begin a perfect fourth above the $d u x$, which fades into the background. The aural result is a prominent A-Hypomixolydian solo line with chorale accompaniment. This is reflected in the overall harmonic scheme of the variation: unlike the chorale and the other variations, which are centered on $\mathrm{E}$, variation III begins with a D major chord, ending on A major. Both canonic voices continue intact until the end, even though canonic strictness is abridged by differences in note values. 
$\mathrm{C}$ naturals are unexpectedly prevalent in this variation. Rather than borrowing from the Dorian mode on $\mathrm{A}$, they suggest a local tonicization of $\mathrm{G}$ major by acting as the seventh of the D major-minor seventh chord $\left(\mathrm{V}^{7}\right.$ in $\mathrm{G}$ ) and as the root of $\mathrm{C}$ major (the subdominant of G). This is followed by the concluding A major triad-a Mixolydian subtonic-tonic cadence. (Alternatively, since the penultimate $\mathrm{G}$ triad contains an added $\mathrm{E}$, the final chord movement could be interpreted as a modally inflected dominant-tonic progression.)

\section{Variation IV}

The chant verse leading to the final variation glorifies the Trinity, and the escalation of the intensity of the musical elements underscores the spiritual elevation intended.

Four subsections, delineated by notations of tempo and timbre changes, comprise the final variation. In the first subsection, which begins in m. 49, an A pedal point underlies triplets which, as indicated by Duruflé's tenuto marks, outline fragments of the chant. Duruflé varies the mode of the chant fragments, as shown in Example 25. 
Example 25. Chant pitches in mm. 49-54, as identified by Duruflé's tenuto marks

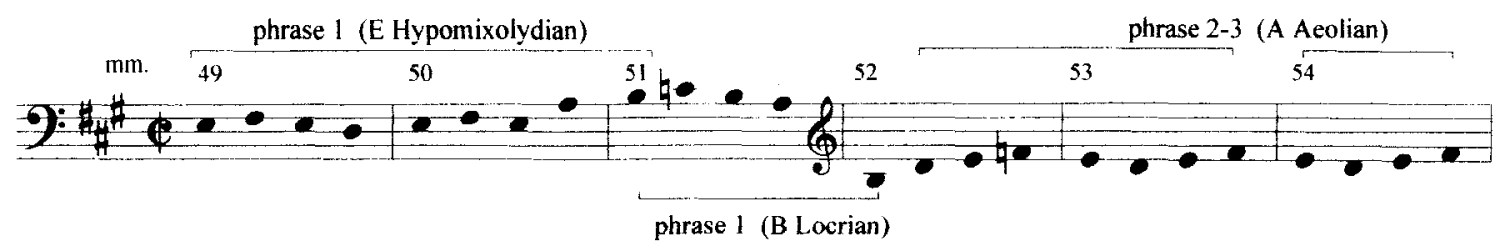

The first fragment of nine pitches begins on $\mathrm{E}$ in measure 49 . The ninth pitch doubles as the beginning of the next fragment, the pitches of which are $\mathrm{B}-\mathrm{C}-\mathrm{B}-\mathrm{A}-\mathrm{B}$. This second fragment is part of a B Locrian transformation of the first phrase of the chant. The following D-E-F-E-D-E-F represents an A Aeolian transformation of a portion of the second and third phrases. Measure 54 restates the last tenor notes of this fragment.

Starting in measure 55 , the soprano line outlines the entire chant on $\mathrm{B}$, with minor alterations. This is imitated in the pedal line at the lower fifth, with variations in the rhythm. Example 26 shows the outer voices of this passage. 
Example 26. Right hand and pedal statements in $\mathrm{mm}$. 55-77 of the fourth variation
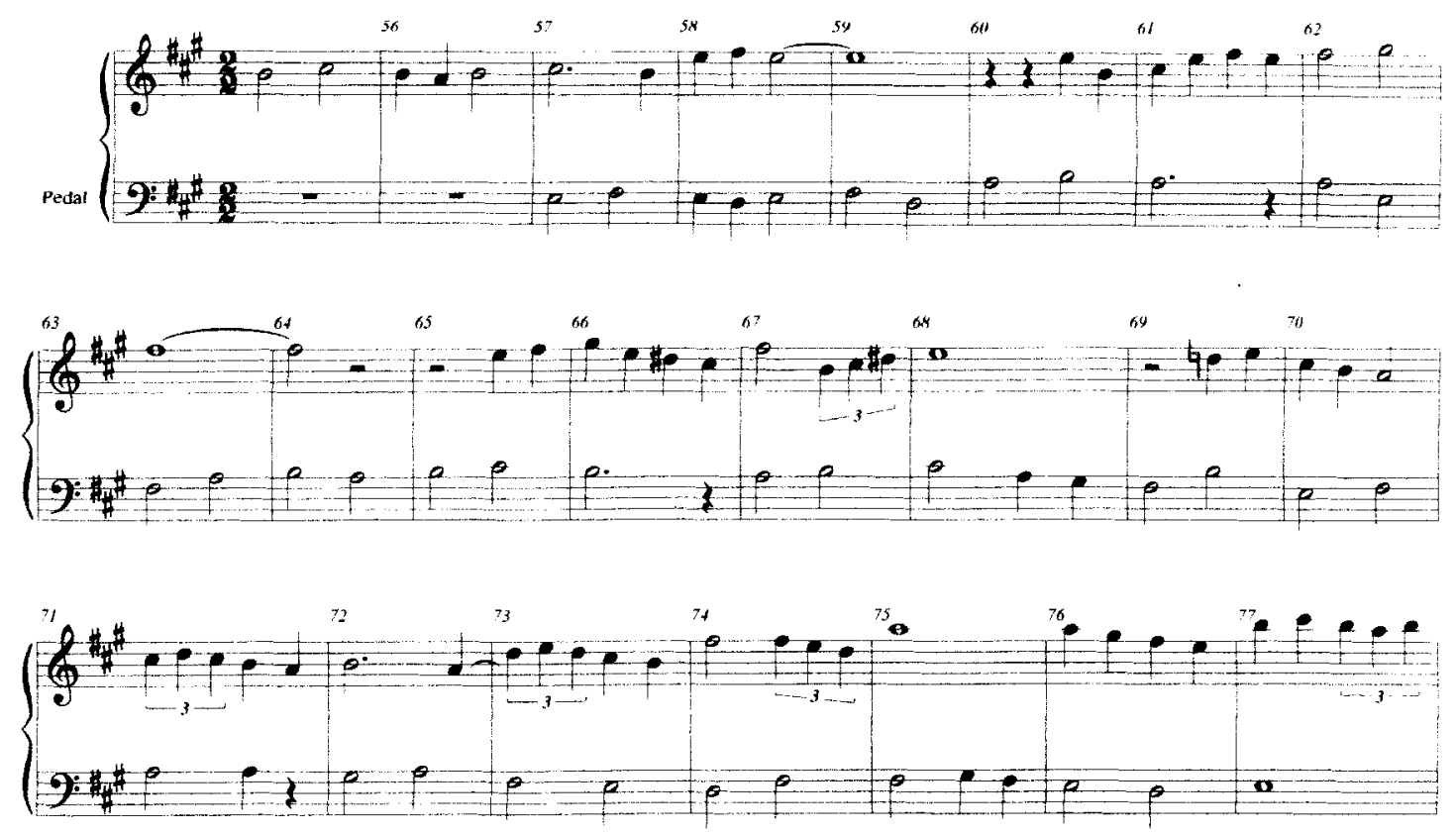

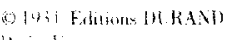

hare. Fratice

D. \& F. 12,016

lowes drots reserve's

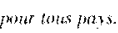

In measure 69 , the $\mathrm{D} 4$ changes the mode of the soprano line from Mixolydian to $\mathrm{B}$

Dorian. The chant statement concludes in the bass line at $\mathrm{m}$. 77 . The adjustment of note values in the soprano allows the literal chant presentation in the pedals. A crescendo from piano to forte spans the length of the first subsection; the brief link to the next subsection continues the crescendo to fortissimo.

The second subsection (mm.81-92) uses fragments from the first and third chant phrases, beginning with a chant fragment from the third phrase found in the top voice of a series of chords. After a repetition of the chordal statement, it moves up a perfect fourth, 
then restates D-E-F\# as D-E-F 4 in preparation for the $\mathrm{B} b$ region that begins in $\mathrm{m} .93$.

(The movement from $\mathrm{E}$ to $\mathrm{B} b$ is, incidentally, the same tritone movement found in the Prélude.)

The third subsection (mm.93-101) intensifies the development of motivic material derived from the chant. For the first time in Variation IV, the triplet figuration incorporates an intact chant fragment in diminution (m. 93, soprano); this is immediately layered with a slower fragment in the lower voice of the same manual (m. 94). Example 27 illustrates.

Example 27. Mm. 93-94: first and third phrase statements

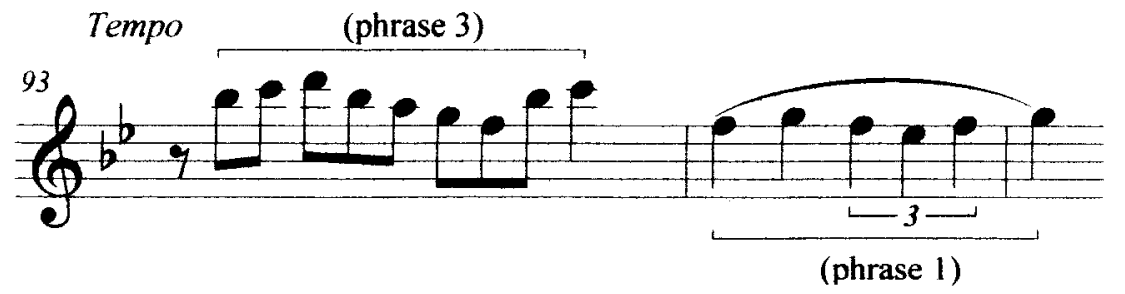

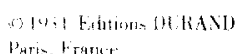

D. \& F. 12,016

Thus drets resertes pion tous persis

The centric region reverts to $\mathrm{E}$ as the final subsection begins in $\mathrm{m} .102$. The dynamic level continues to increase until the fff climax is reached in $\mathrm{m}$. 106. Here the tempo slows momentarily; then both the basic tempo and the surface rhythm speed up again as a brilliant codetta (111-119) leads to the final E major triad. 


\section{CHAPTER III ENDNOTES}

1. Frazier, Maurice Duruflé, 46.

2. Zehr, "Selected Organ Compositions," 4.

3. McIntosh, J.S.,"Organ Music," 47.

4. Driscoll, "Performance Guide," 62-64.

5. Robert L. Bozeman, "Re: Duruflé Opus 4," email message to author, 20 February 2010. 


\section{CHAPTER IV}

QUATRE MOTETS

In the thirty years that separate the writing of Opus 4 (1930) and Opus $10(1960)$, European composers pushed the envelope of tonality and other elements of the Western musical tradition. Both the German National Socialists and the Roman Catholic Church used their significant influence to discourage avant-garde and atonal or rhythmically unconventional compositions. As a very religious Catholic and a person most comfortable conforming to convention, Duruflé eschewed the new trends, embracing the familiar. Following the Prélude, Adagio, and Choral varié, Duruflé wrote two orchestral pieces and two organ works before composing his Requiem in 1947. Written for chorus, organ and large orchestra, it was his most ambitious work to that point, and he incorporated Gregorian chant throughout. Quatre Motets, Opus 10 is Duruflé's first work to follow the Requiem. Written for unaccompanied chorus in 1960, the Four Motets are dedicated to the man who had coached him in the study of the rhythmic interpretation of the Solesmes method of Gregorian chant, Auguste Le Guennant, head of the Institut gregorien de Paris. ${ }^{1}$ Each of the four motets uses a chant found in the Liber Usualis, and the original mode of the chant is retained somewhere in the motet, although a second mode may be 
used in the composition. In this discussion, each motet will be addressed after remarks about the chant on which it is based.

\section{Ubi caritas}

The first of the motets is a ternary setting for SATTBB voices, loosely based on the antiphon Ubi caritas et amor, a hymn originating in tenth-century France. The original version of the antiphon is found on pp. 675-676 of the Liber Usualis in the chants for Maundy Thursday. Following the sermon of the Solemn Evening Mass of the Last Supper, celebrated between vespers and compline, the rite of foot washing is observed, during which a series of antiphons with verses is sung. Ubi caritas is the eighth of those antiphons.

The chant is composed in the Hypolydian mode with lowered fourth degree, using

only the pitches $\mathrm{C}, \mathrm{D}, \mathrm{F}, \mathrm{G}, \mathrm{A}$, and $\mathrm{Bb}$. At the Amen, $\mathrm{E}$ is added as a cadential leading tone. $\mathrm{F}$ is the final; $\mathrm{A}$ is the reciting tone. The initial phrase of the melody contains two contiguous sequential gestures of three rising notes on $\mathrm{F}$ plus a balancing descent, beginning on $\mathrm{A}$. The pitch A receives greatest prominence in the chant. Ubi caritas is reproduced as Example 28. 


\section{Example 28. Ubi caritas}
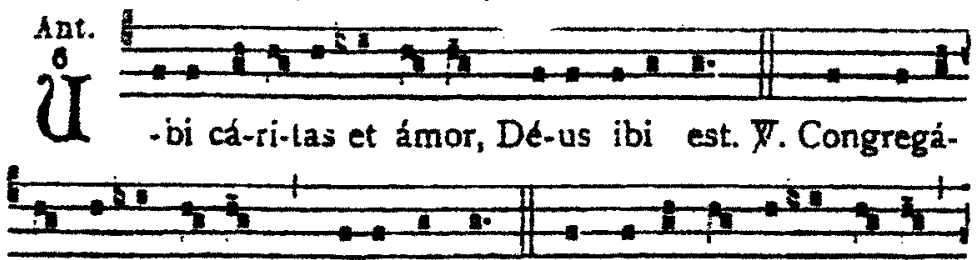

vit nos in únum Chrísti ámor. $\nabla$. Exsultémus, et in ipso

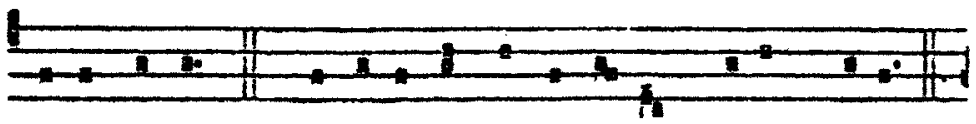

jucundenur. $\nabla$. Time-ámus, et amémus Dé-um vívum.

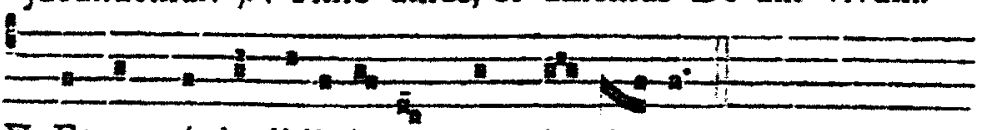

T. Et ex córde di-ligámus nos sin-cé- ro.

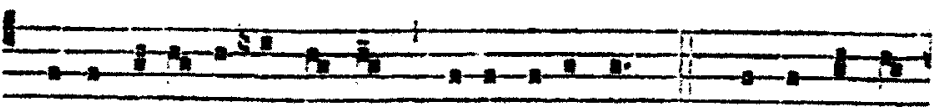

Aimt. L bi cá-ri-tas et ámor, Dé-us ibi est. T. Simul ergo

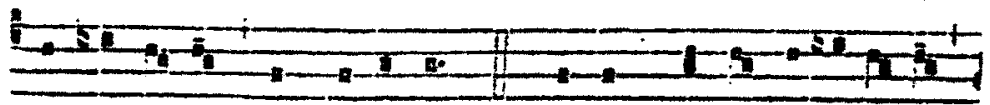

cum in únum congregámur: $\vec{T}$. lè nos ménte di- vidámur

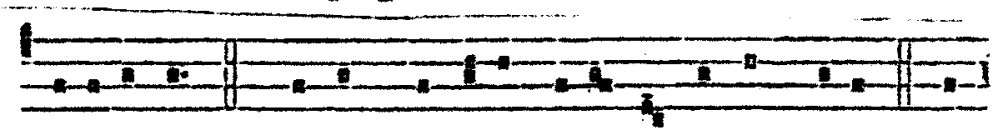

cave-ámus. ,T. Céssent júrgi-a ma-ligna, céssent lí-tes.,T.Et

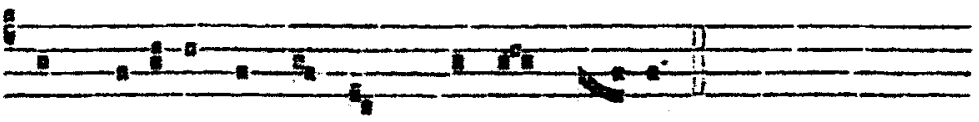

in médi-o'nóstri sit Christus Dé- us.

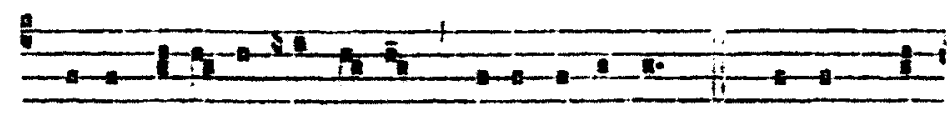

-thi. Ubi cá-ri-tas et ámor, Dé-us i-bi est. F. Simul quo-

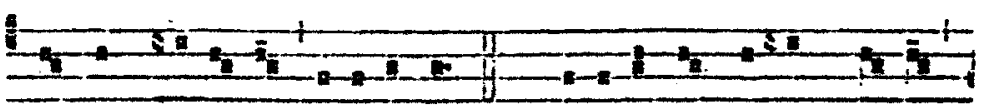

que cum be-á-tis vide-ámus. F. Glo-ri-ánter vúltum tú- um,

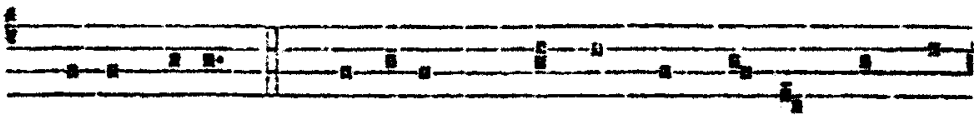

Christe Dé-us: $\Gamma$.Gaudi-um, quod est imménsum, atque

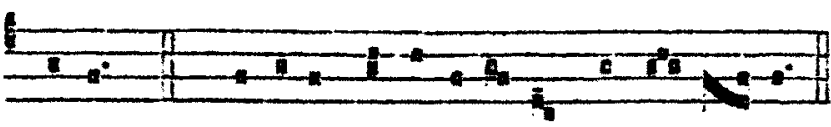

próbum. F. Saécula per infiní-ta saecu- ló- rum. 
The text unfolds as three sets of five lines, each comprising an antiphon with four versets, shown in Example 28. In each five-line group, the music of the antiphon and the first and second versets is similar; both versets subtract a punctum to accommodate the texts which have one syllable fewer than that of the antiphon. The third and fourth versets are likewise similar to each other, the fourth verset being an ornamented version of the third. Accordingly, the melodic form for each of the three sections of text is a, a, a, $b, b^{\prime}$. Example 29 shows a transcription into modern notation of the antiphon and the fourth verset, that is, the "a" and " $b$ " melodic phrases.

Example 29. Transcription of two versets of Ubi caritas

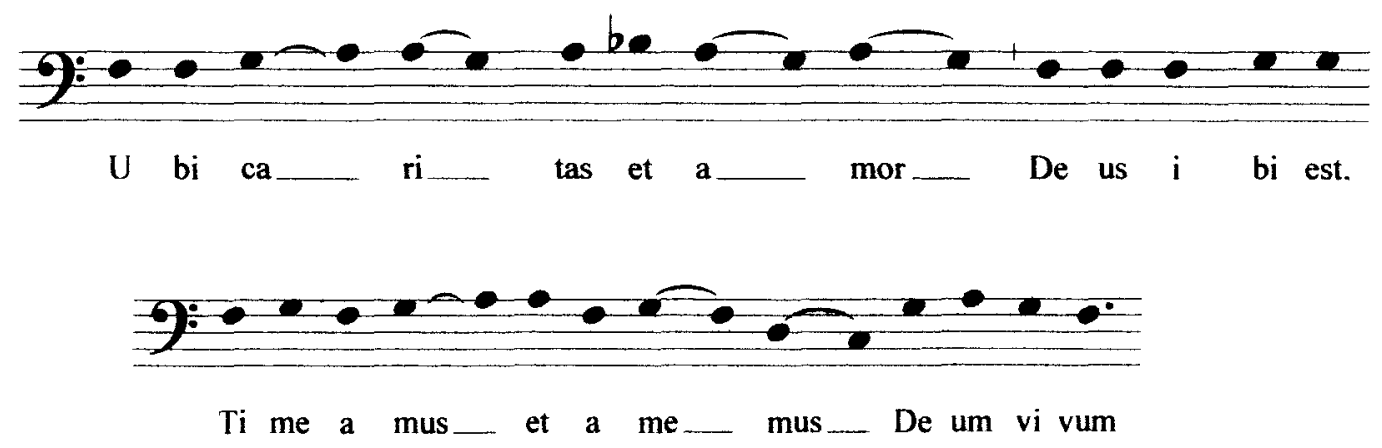

Duruflé sets only the first section of the text, followed by the antiphon and a final Amen. The text and its translation are given in Example 30. 
Example 30. Text and translation of Ubi caritas

Line 1: Ubi caritas et amor, Deus ibi est. Where there is charity and love, God is there.

Line 2: Congregavit nos in unum Christi The love of Christ has gathered us as amor. one.

Line 3: Exsultemus, et in ipso jucundemur. Let us rejoice and be glad in it.

Line 4: Timeamus, et amemus Deum Let us honor and love the living God. vivum.

Line 5: Et ex corde diligamus nos sincero. From a sincere heart let us love one another.

The thirty-nine measure motet is divided into three nearly equal sections. The first and final sections consist of fourteen and eleven measures in $\mathrm{E} b$, with the indication piano. Duruflé begins the piece with the opening of the chant transposed down one step. The first four measures of the motet, sung by the first group of altos, are echoed by the second alto section in measures 5-8.1. The alto line begins pressing ever upward from the first measure. In the first fourteen measures, the line hovers around $\mathrm{E} b$, passing to $\mathrm{F}$ and $\mathrm{G}$ and reaching $\mathrm{A} b$ in measures 2,9 , and 12 . The harmony of both ten-beat phrases accompanying the first text line (mm. 1-4 and 5-8.1) moves from $\mathrm{E} b$ to $\mathrm{B} b$ in a four-voice texture. The first fragment of nine pitches begins on $\mathrm{E}$ in measure 49 .

Consecutive perfect intervals and both first and second inversions abound in these measures. Horizontal movement also presses toward perfect intervals, although the exchange of inner voices prevents the aural effect normally created by perfect intervals. Dissonance is provided by the inner lines which repeat the dyad $\mathrm{E} b-\mathrm{B} b$, varied only by 
the addition of $\mathrm{C}$ until the cadence. In the measures which follow, parallel seconds between the tenor and bass resolve after the caesure at measures 3.2 and 7.2. A plagal cadence in $\mathrm{E} b$ ends the section.

The middle section of fourteen measures is performed mezzo forte. This section is not set in a particular centricity but includes brief, transitory tonicizations.

From the second half of measure 8 through measure 14, Duruflé's composed material both quotes and gently rearranges the original chant. For instance, the newly composed material of measures 8.2-14 both inverts the contour of measure 1 and incorporates a partial retrograde of the chant. The newly composed phrase creates the illusion of extending the melodic range higher, although its highest pitch is $\mathrm{Ab4}$, exactly the same pitch as the apex of the first phrase. The illusion results from the placement of the Ab4 on an accented syllable in the newly composed phrase. Example 31 compares measures 8-11 to measures 1-4 and the basic movement of the two melodic fragments. The second of each is the inversion of the first. 
Example 31. Chant passages in Ubi caritas compared to the motet melody

Motet measures 1-4, based on the chant

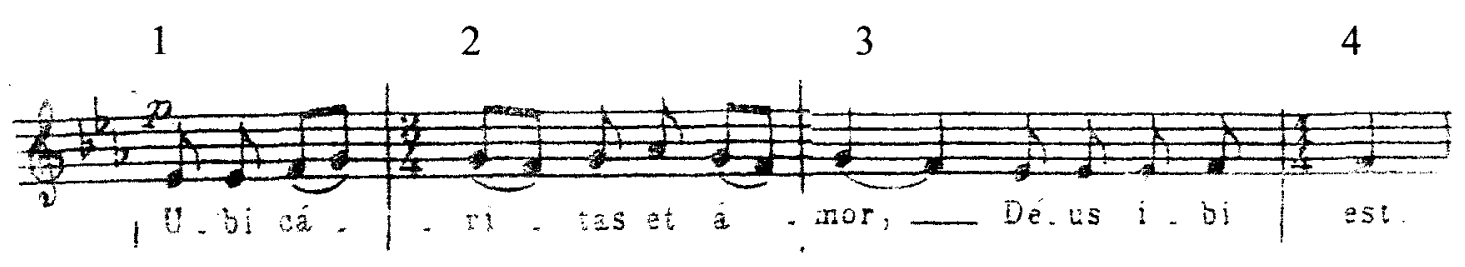

Motet, measures 8.2-11.2

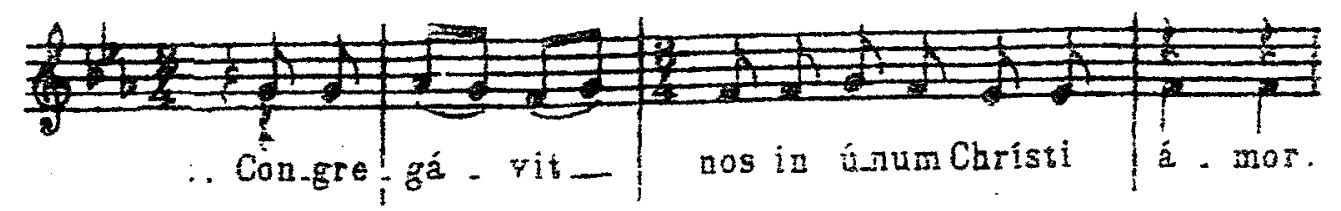

(6) 1960 Editions Dourand

Paris. France:

D. \&.F. 13901

lous droils reserves pour tous pays.
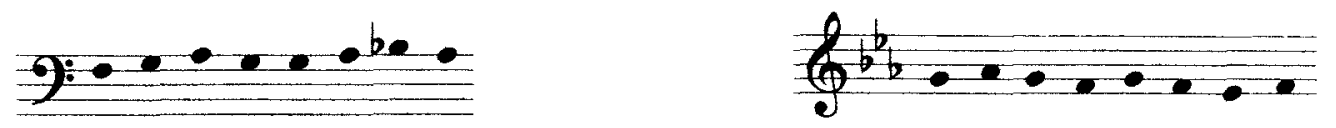
Table 1 shows the organization of the text and melody.

\begin{tabular}{|c|c|l|c|c|}
\hline Text Line & Measure & Melodic Source & Choral Section & Centricity \\
\hline 1 & $1-4$ & Chant & $1^{\text {st }}$ choir alto & $\mathrm{Eb}$ \\
\hline 1 & $5-8 \mathrm{a}$ & Chant & $2^{\text {nd choir alto }}$ & $\mathrm{Eb}$ \\
\hline 2 & $8 \mathrm{~b}-11 \mathrm{a}$ & Duruflé's melody & $1^{\text {st }}$ choir alto & $\mathrm{Eb}$ \\
\hline 2 & $11 \mathrm{~b}-14$ & Duruflé's melody & $2^{\text {nd }}$ choir alto & $\mathrm{Eb}$ \\
\hline 3 & $15-18 \mathrm{a}$ & Chant & Soprano & $\mathrm{Bb}$ \\
\hline 4 & $18 \mathrm{~b}-21 \mathrm{a}$ & Duruflé's melody & unison alto & $\mathrm{F}$ \\
\hline 5 & $21 \mathrm{~b}-24 \mathrm{a}$ & Duruflé's melody & unison alto & $\mathrm{F}$ \\
\hline 5 & $24 \mathrm{~b}-28$ & Duruflé's melody & unison alto & $\mathrm{Bb}$ \\
\hline 1 & $29-32$ & Chant & $1^{\text {st }}$ choir alto & $\mathrm{Eb}$ \\
\hline Amen & $33-39$ & Chant & unison alto & $\mathrm{Eb}$ \\
\hline
\end{tabular}

Table 1

Summary of Duruflé's use of chant materials in Ubi caritas

The first measures of Durufle's setting twice quote the text and music of the chant transposed to Eb. Congregavit nos in unum Christi amor is then sung twice to the new melody in the same transposition.

At the start of the second section (m. 15) the chant is transposed to $\mathrm{B} b$. Tempo and volume increase as the soprano section sings the third line of the chant. The shift in centricity, addition of higher voices, resumption of the original tempo, and increase in volume musically paint "exsultemus," an invitation to rejoice. Altos sing the fourth and 
fifth line, where the chant is transposed to F. When the fifth line is repeated, the chant is transposed to $\mathrm{B} b$. The altos repeat the first line, with the chant transposed to $\mathrm{E} b$. Though the chant remains in the Hypolydian mode, the accompanying voices generate a harmony based on the cycle of fifths until a single beat of a $\mathrm{Bb}$ major chord leads to a return of $\mathrm{E} b$, a centricity which is sustained until the final cadence. Mm. 29-32 replicate mm. 1-4. The final measures, mm. 33-39, quote for the first time the music of the final versets of the first strophe of the chant, although Duruflé substitutes "Amen" for the original text, as shown in Example 32.

Example 32. Final verset of chant adapted as "Amen" melisma

Transcription of et ex corde diligamus

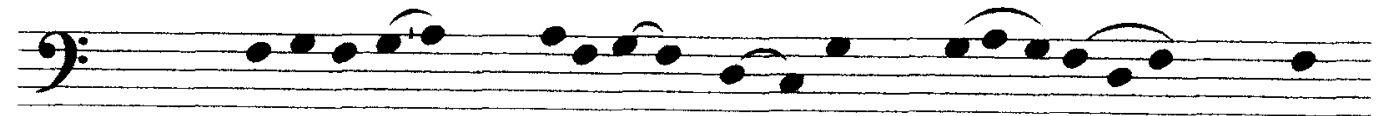

Et excor de di li ga mus nos $\sin { }_{-}$ce ro

Motet $\mathrm{mm} . .33-39$, unison alto

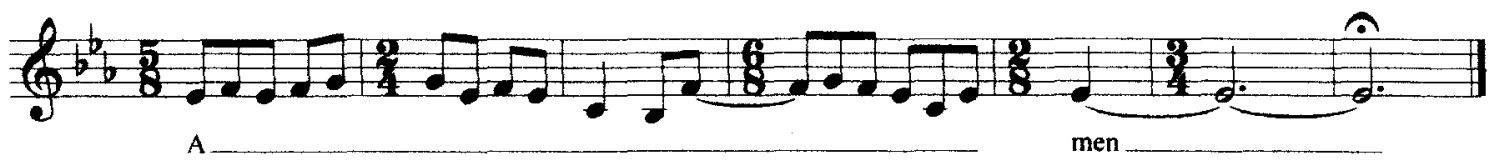


Duruflé's harmony is essentially tertian, with triads and seventh chords sometimes colored by accented and unaccented non-chord tones which briefly produce major seconds, as in mm. 29.2, 31.1,33, and 35. He uses a cycle of fifths to wander through several tonal environments by using the bass as a dominant substitute, moving it by ascending fourth or descending fifth even when it is not the root of the chord. For example, the bass $\mathrm{G}$ of $\mathrm{mm}$. 15-17 eventually leads to $\mathrm{C}$ major, yet this $\mathrm{G}$ underlies the following chords: $\mathrm{Gm}, \mathrm{Gm} 7, \mathrm{Cm} 7, \mathrm{Aø}$, and $\mathrm{EbM}$.

Hints of functional relationships pervade long-range phrase outlines and cadences. Phrase 1 begins on $\mathrm{E} b$ and ends on $\mathrm{B} b$. Line 2 ("Congregavit") is repeated to form two phrases; the first begins on $\mathrm{Eb}$ and ends on $\mathrm{Bb}$ (with an "authentic" $\mathrm{FM}$ to $\mathrm{BbM}$ ), while the second outlines a circular $\mathrm{E} b$ to $\mathrm{E} b$ motion (concluding with a "plagal" $\mathrm{A} b$ to $\mathrm{E} b$ cadence). Line 3 ("Exsultemus") moves from $\mathrm{G}$ minor to $\mathrm{C}$ major, and line 4 ("Timeamus") from F major to C major. The fifth line ("Et ex corde") begins with an F major triad and ends with a plagal $\mathrm{B} b-\mathrm{F}$ cadence; its repetition begins on $\mathrm{B} b$ and ends with a plagal $\mathrm{A} b-\mathrm{E} b$ motion. An $\mathrm{A} b$ major harmony with added tones underlies the final "Amen" melisma, suggesting a plagal cadence as it moves to the concluding Eb major triad.

The natural lines of the chant phrases form an arch, with either apogee or perigee at each phrase center. The form of the motet also forms an arch, since the center section contains both the highest and lowest pitches of the soprano line and is differentiated from the outer sections both in volume and in pitch. 
Tota pulchra es, Maria

The second motet, Tota pulchra es, is based on three of the five antiphons for Second Vespers on the Feast of the Immaculate Conception of the Blessed Virgin Mary, celebrated on December 8 . The portions of the chant Duruflé uses are reproduced in Example 33, the transcription is provided in Example 34, and the text and translation are given in Example 35.

Example 33. The antiphons on which Tota pulchra es, Maria is based (Liber Usualis 1320-21)
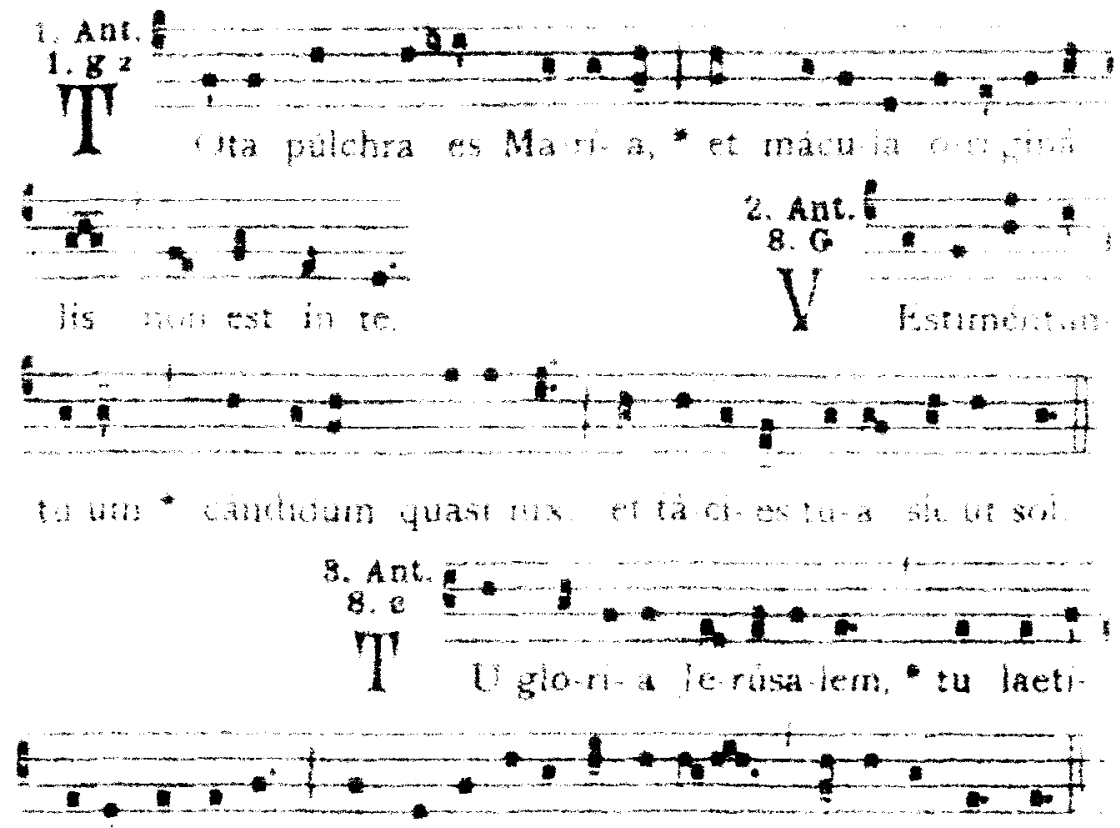

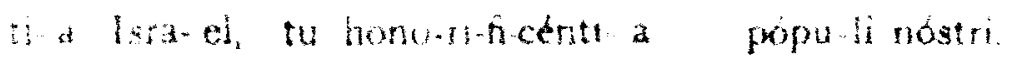


Example 34. Transcription

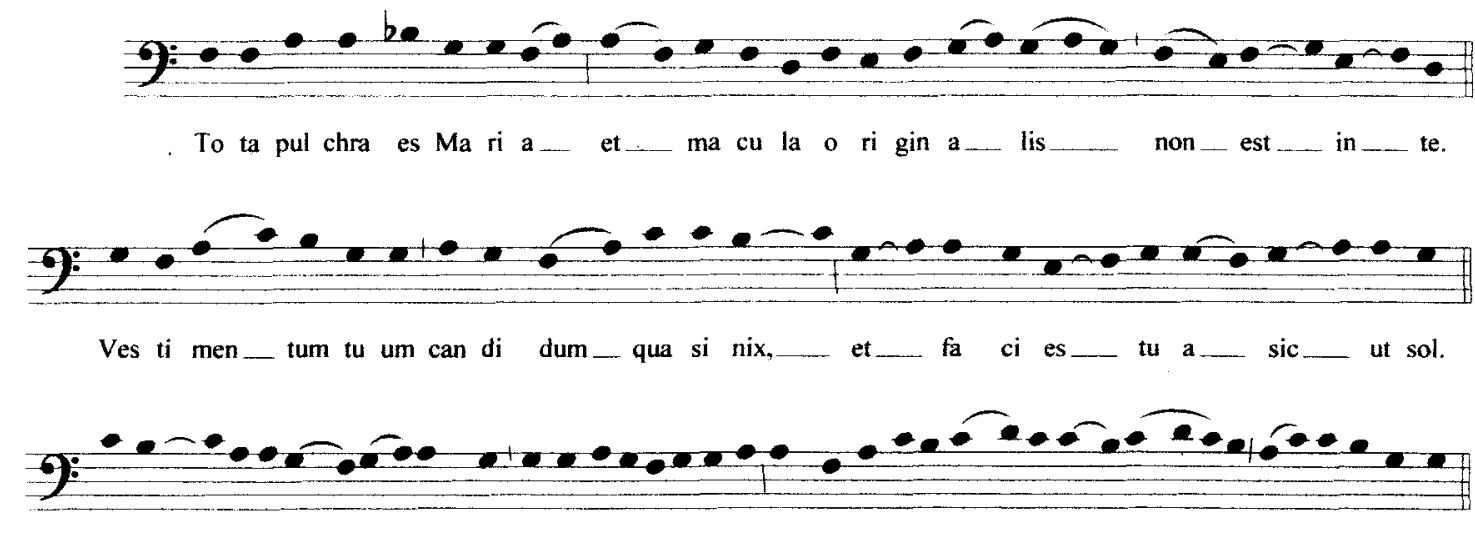

Tu glo__ ri a Je__ ru_sa lem, tu lae ti ti a Is ra el, tu ho no ri fi cen_ti a po pu li nos tri.

Example 35. Text and translation

Antiphon 1: $\quad$ Tota pulchra es Maria et macula originalis non est in te.

You are all fair, O Mary, And there is no stain of original sin in you.

Antiphon 2: Vestimentum tuum candidum quasi nix et facies tua sicut sol.

Your raiment is as white as snow, and your face is like the sun.

Antiphon 3: Tu gloria Jerusalem, tu laetitia Israel, tu honorificentia populi nostri.

You are the glory of Jerusalem, the joy of Israel, the honor of our people.

The music of the first plainchant antiphon is in the Dorian mode (albeit with lowered sixth scale degree); the ambitus is from $\mathrm{D} 3$ to $\mathrm{Bb} 3$, and the final is $\mathrm{D}$. As the text of the second antiphon points to purity and the shining of the sun, the chant melody, with its final of $\mathrm{G}$ and its ambitus of $\mathrm{E} 3$ to $\mathrm{C} 4$, changes to the brighter Hypomixolydian mode. 
The music of the third antiphon is likewise in Mode 8, wth a final on $\mathrm{G}$ and an ambitus from F3 to D4.

The antiphons were planned originally as independent responses sung before and after the reading or chanting of the day's psalm. Duruflé, however, sets the three antiphons as a continuous composition, omitting the Gloria that would have been included in the liturgy but reiterating the "Tota pulchra es, Maria" antiphon as a refrain between the second and third antiphons and (in incomplete form) after the third antiphon.

The form of the motet is ABACA' Coda. The sections and corresponding measure numbers are shown in Table 2.

\begin{tabular}{|c|c|}
\hline Section & Measures \\
\hline A & 1 through 13.1 \\
\hline B & 13.2 through 22 \\
\hline A & 23 through 35 \\
\hline C & 36 through 43 \\
\hline A $^{\prime}$ & 44 through 53 \\
\hline Coda & 54 through 56 \\
\hline
\end{tabular}

Table 2

Formal organization of Tota pulchra es

Duruflé's setting is for womens choir, and he creates a three and four-voice texture by dividing both the second sopranos and the altos, although never concurrently. 
The writing is polyphonic with voices independent both in melody and rhythm. Contrary motion between voices is common. The chant is fragmented in the motet, passing among the voices. The chant tune is altered in myriad ways, with melodic and rhythmic changes and with the original line expanded or reduced.

Perusal of the motet reveals a pattern in Duruflés use of original material in the melodic line. The composition employs the chant until the minor divisions after "originalis," "quasi nix," and "Jerusalem," then uses newly composed music. Example 36 compares the original Tota Pulchra es to Duruflé's mm. 1-6 in the first soprano; the similarity is apparent when the contour of the line and the size of intervals are compared.

Example 36. Comparison of the first phrase of the first antiphon with the motet

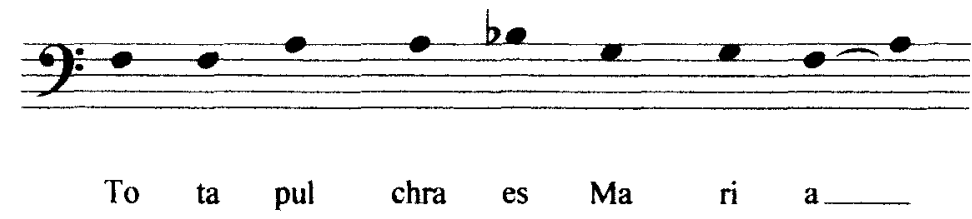

Motet mm. 1-6, first soprano

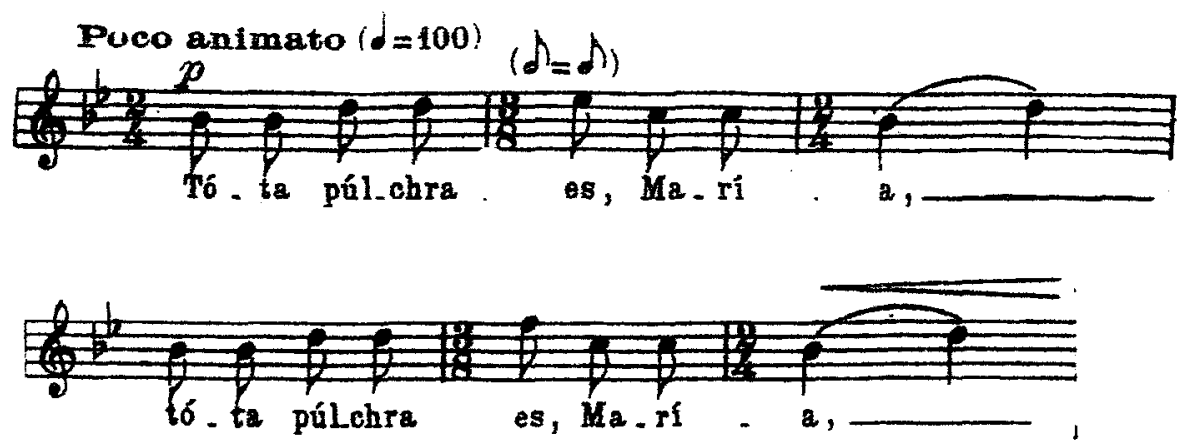

(0) 190 Fditions Durand 
The counterpoint of mm. 1-6 may be derived from the chant. Example 37 compares the counterpoint of the second soprano part with the plainsong setting of "originalis." The beginning of each phrase simply shifts the melody to another scale degree, retaining the stepwise line while altering the quality of the intervals.

Example 37. Comparison of the chant "originalis" with mm. 1-6 of the motet

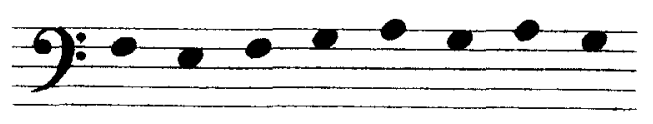

o ri gi na_ lis

Soprano II, mm. 1-3

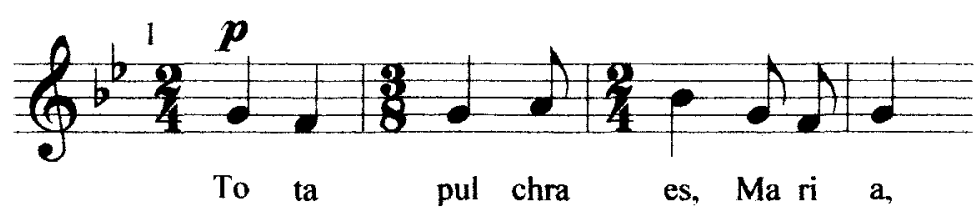

Soprano II, mm. 4-6

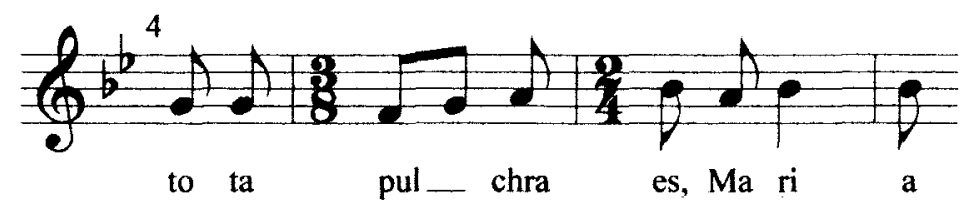


The setting of the second antiphon begins with the pickup to $\mathrm{m}$. 14. The chant melody of Vestimentum tuum candidum quasi nix is the model for the first soprano line in mm. 14-17.

The continuation of the plainsong antiphon et facies tua sicut sol, on the other hand, is the source not of the soprano melody but of the first alto part of mm. 16-18, as shown in Example 38.

Example 38. Derivation of mm. 16-18, Alto I, from chant

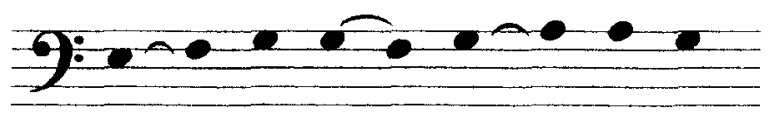

es__ tu a__ sic ___ ut sol.

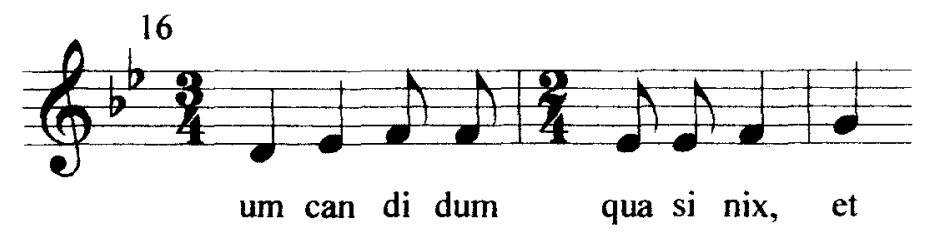

Durufle's setting of the text et facies tua sicut sol is freely composed, although the melody of the final two words of the phrase recalls the punctum mora that precedes the minor division of the plainsong antiphon (quasi nix in the chant). Duruflé may have chosen a rising rather than a falling melodic ending for his cadence (mm. 21-22) in order 
to end the B section with a less final-sounding cadence in anticipation of the reprise of the A section, once again with the text Tota pulchra es, Maria (mm. 23-35).

Duruflé begins the third antiphon in m. 35. Example 39 shows that the first soprano voice closely follows the original $t u$ gloria Jerusalem, reversing the direction of the pitch preceding the minor division and assigning a single pitch to "ru," rather than two as in the original.

Example 39. Comparison of the third antiphon of the chant with mm. 36-37

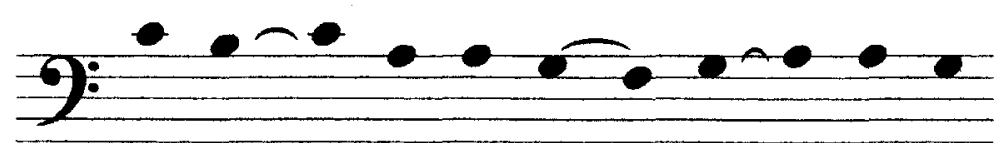

Tu glo__ ri a Je__ ru___ sa lem

Soprano I, mm. 36-37

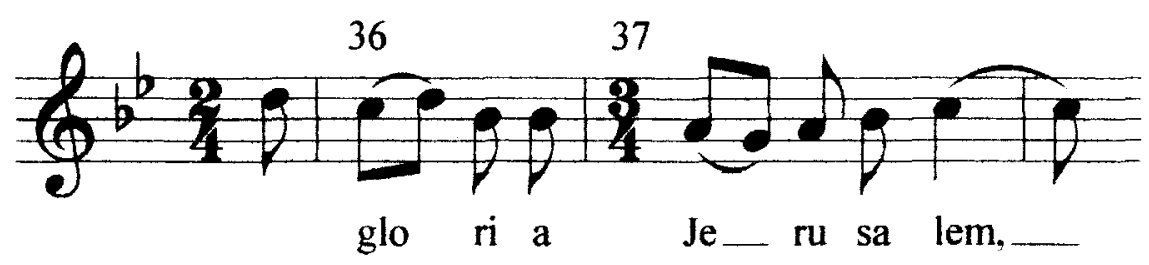

The setting of tu laetitia Israel is freely composed, maintaining the character of plainsong but extending the range of the original chant. Duruflés setting of $t u$ honorificentia populi nostri, on the other hand, returns to the chant melody with one interval change and the omission of the torculus between honorificentia and populi $(\mathrm{mm}$. 40-43). The two versions are compared in Example 40. 
Example 40. Comparison of chant and motet on words honorificentia populi

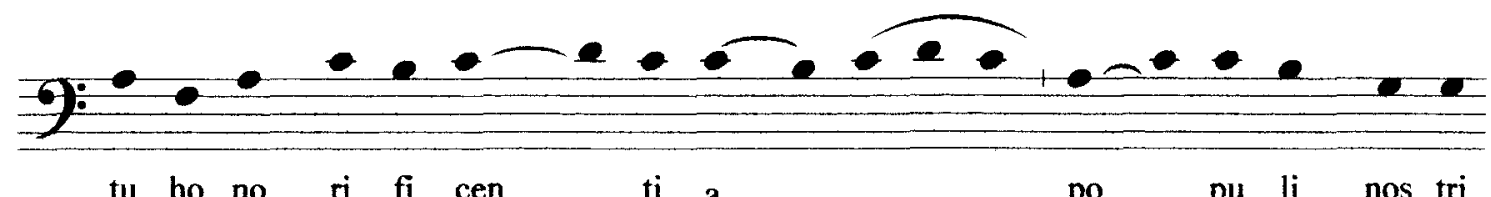

Soprano I line mm. 40-43

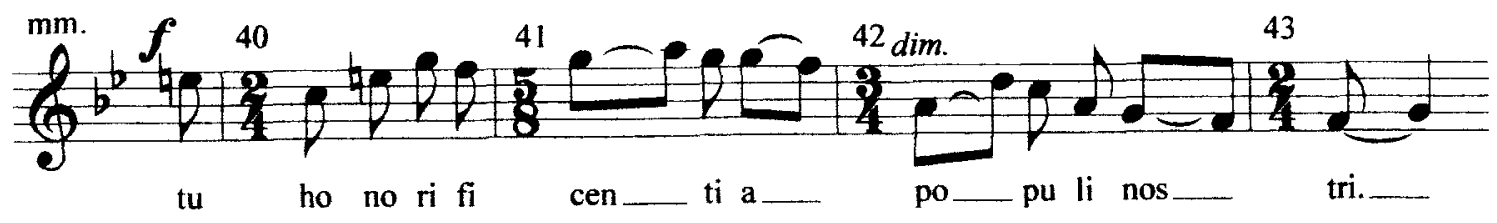

(1960) Fólitions Durand

Paris. France

I). $\mathrm{F} .13901$

Tous droits reservers pour tous pals.

A tapering of tempo and volume begins with a diminuendo in $\mathrm{m} .44$ and a poco rit. and senza rigore in $\mathrm{mm} .46-48$. The rallentando of $\mathrm{m}$. 54 accompanies the fading to pianissimo as the music ends with an open fifth. 


\section{Tu es Petrus}

The source of the third motet is the fifth antiphon of the first vespers service of the Feast of the Holy Apostles Peter and Paul, found on page 1515 of the Liber Usualis. The text is from Matthew 16:18 ("You are Peter, and upon this rock I will build my church"). ${ }^{2}$ A copy of the chant is provided in Example 41. The movement is mostly conjunct, and the largest interval is the twice-occurring major third.

\section{Example 41. Tu es Petrus}
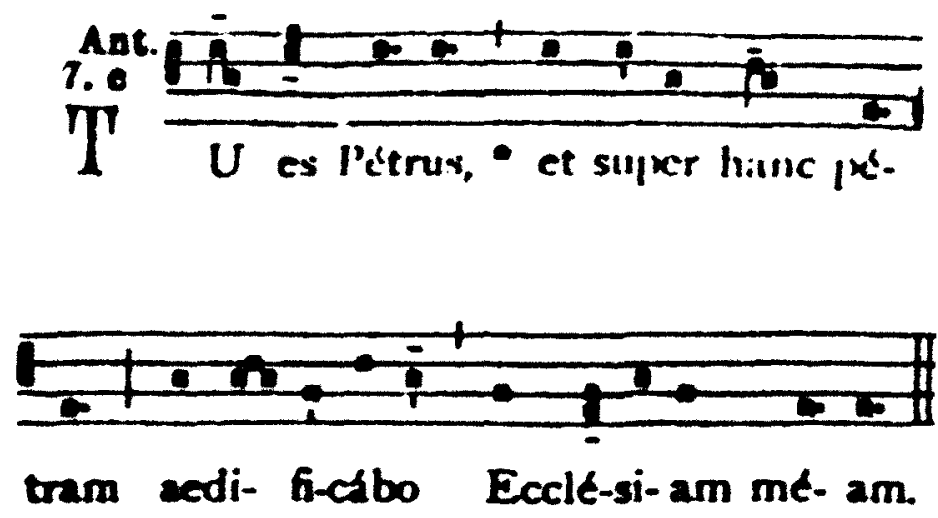

The mode of the chant is Mixolydian with a final on G. Duruflé uses the modal

$\mathrm{F}$ G only in the final five measures of the twenty-three measure motet, having liberally

distributed F\# throughout mm. 6-18. Four contiguous melodic fragments comprise the chant, separated by notated pauses. Example 42 displays and numbers these fragments. 
1.

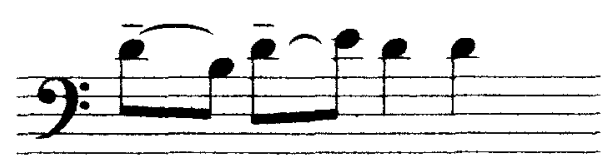

$\mathrm{Tu}$ es Pe trus

2.

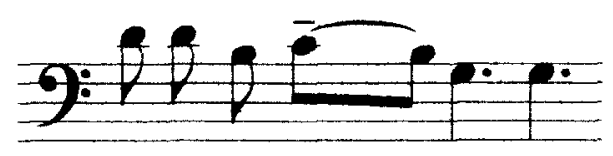

et su per hanc___ pe tram

3.

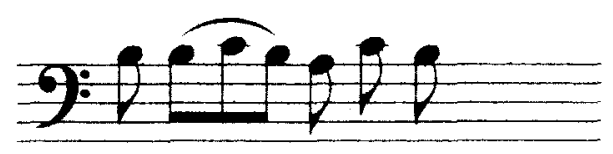
ae di_fi fa bo

4.

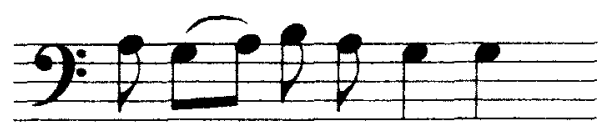

Ec cle__ si am me am

The motet begins with repeated statements of $t u$ es Petrus in imitation followed by the remaining words of the antiphon. The first complete statement of the text concludes in measure 12 as the music cadences on B. However, the momentum generated by the fast tempo and continuing movement of the inner voices inhibits a sense of formal punctuation at this cadence. The words aedificabo ecclesiam meam are reiterated by the singers twice before the motet ends. 
From the beginning measures, the avoidance of a lowered seventh reflects Durufle's flirtation with $\mathrm{G}$ major, beginning with the stretto entrances of the chant. The tenors begin the fragment on $\mathrm{D}$. This is followed by basses on $\mathrm{B}$, the altos on $\mathrm{G}$, and the sopranos on $\mathrm{D}$, all at one-beat intervals. Thus, the composer highlights the members of the $\mathrm{G}$ major triad in the first sounds of the motet.

Duruflé continues enriching the music with chant or chant-derived material. The soprano line begins with a statement of the incipit, followed by a varied statement; this is followed in turn by the second fragment, transposed up a third. In measure 9 , the third fragment is transposed up a perfect fourth except for the E-F\# whole step that replaces the original semitone. In the beginning of measure 11, a variant of the fourth fragment is sung a major third higher than the original, helping to establish B centricity, which is a major third higher than the original; on the second beat of measure 12, three of the four voices sing $\mathrm{B}$. The third fragment then appears in sequence, first at the original pitch and then a minor third higher. Finally, the end of the chant arrives in mm. 16-18 centered on the pitch D, a perfect fifth higher than the original. (An échappée embellishes the original highest pitch, extending the range of this fragment upward by a half step.)

The lower voices sing counterpoint that is chant-like in its conjunct lines and generally narrow range, but most of this material is freely composed. An exception is the bass of mm. 15-17, which quotes the plainsong setting of aedificabo (fragment 3) almost literally with the addition of one upper neighboring tone. 
In Duruflé's version, the sopranos have aedificabo with the torculus gesture several times, and he accommodates the chant rhythm through a metric change to fiveeight. The final time the sopranos sing aedificabo, the melodic line is varied. This is shown in Example 43.

Example 43. Uses of aedificabo in the soprano, each in 5/8 meter
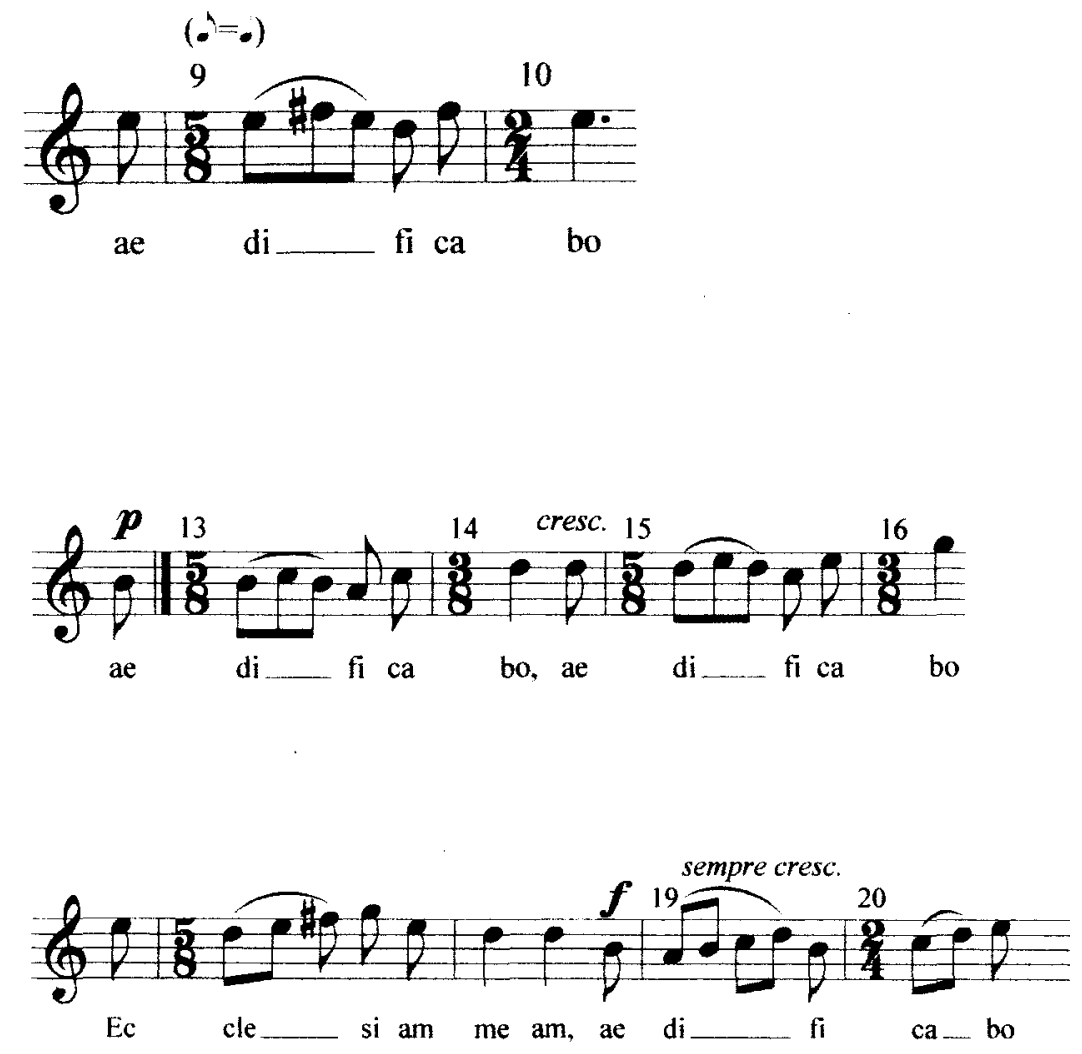
The harmonic path here is a product of the cycle of fifths. Example 44 summarizes the harmonic succession.

Example 44. Cycle of fifths in mm. 13-15

measure 13 measure 14 measure 15

Em Am $\quad D^{6} \quad G^{6} \mathrm{C}$

This motet differs markedly from the others in its volume as well as its form.

Because it is very fast and loud, the listener experiences a wave of diatonic sound resulting from tall tertian constructions. The first six measures reflect $\mathrm{G}$ with added tones. The following measures migrate through the "white" key cycle of fifths, with seventh and ninth chords defining the sound. Duruflé concludes with a plagal cadence from a $\mathrm{C}$ triad to the final $\mathrm{G}$ major triad. 


\section{Tantum ergo}

Although the previous motets are settings of antiphons, Duruflé chose a strophic hymn for the final piece. Found on page 954 of the Liber Usualis, Tantum ergo is designated as the chant which is used during the Benediction of the Blessed Sacrament on the feast of Corpus Christi, during which the monstrance is removed from the sanctuary. The text is found in the final two verses of the six-verse hymn by Thomas Aquinas,

\section{Pange lingua.}

The chant is in E Phrygian with an ambitus of D3 to D4. The final is E, and the dominant is C. The chant is reproduced in Example 45, its transcription in Example 46, and the text and its translation in Example 47. 

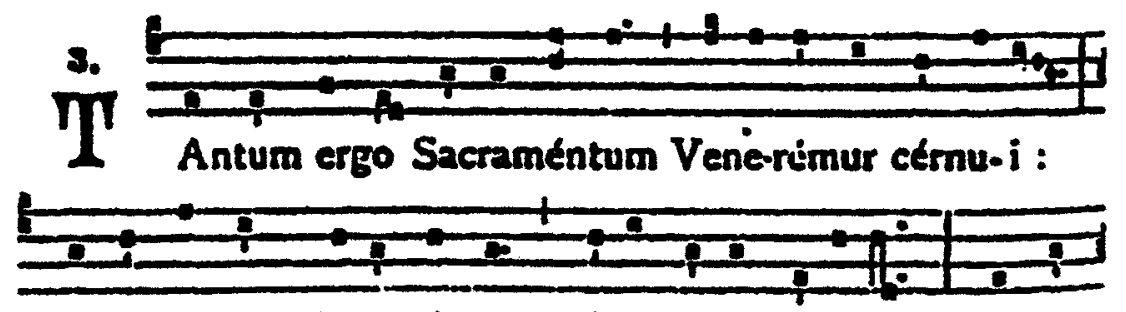

Et antiquum documéntum Nóvo cédat ri-tu-i : Praśstet

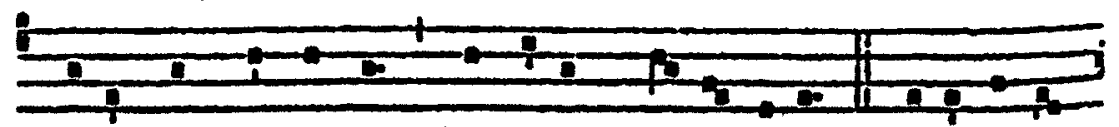

fides supplementum Sénsu-um de-fíctu-i. Geni-tó-ri,
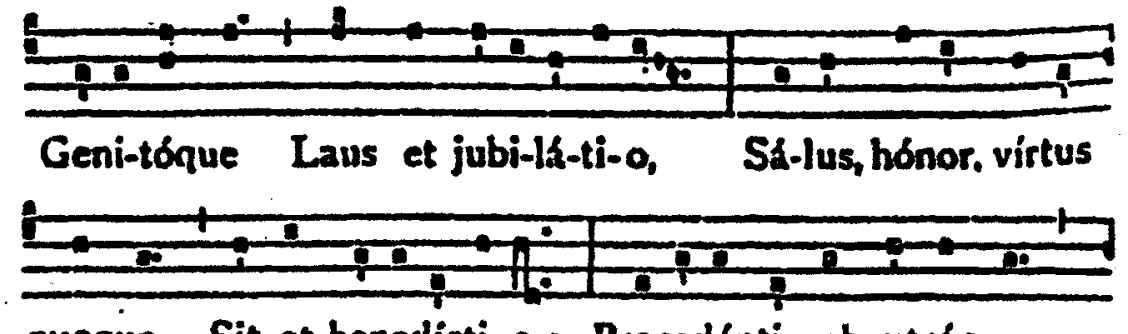

quoque Sit et benedicti-o: Procedénti ab utróque

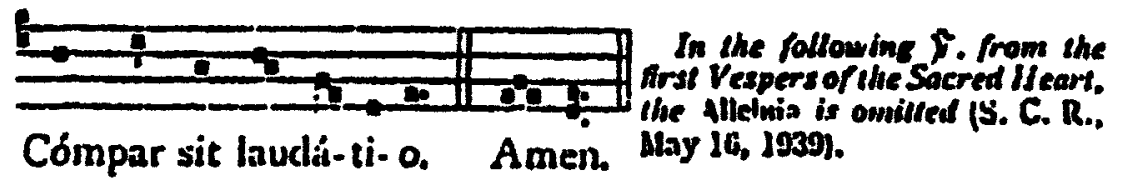

Example 46. Tantum ergo transcription
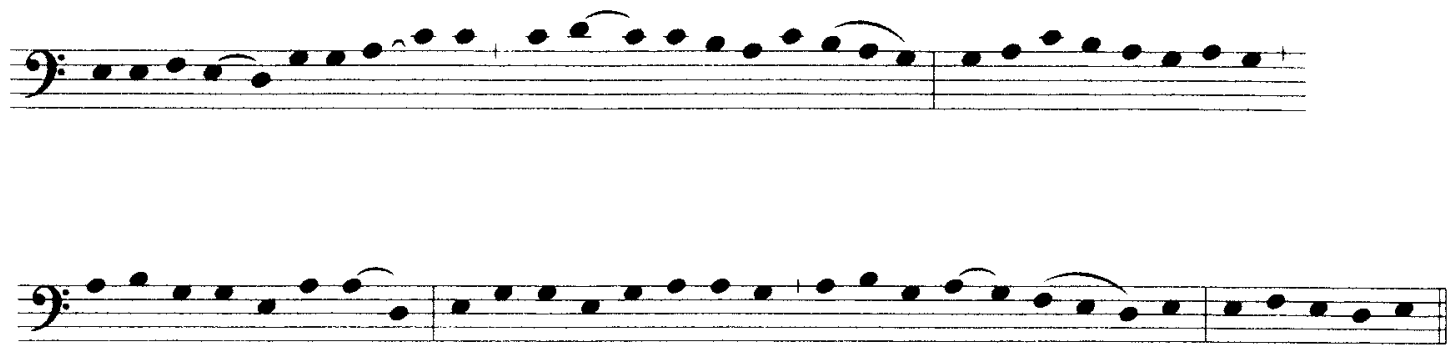
Example 47. Text and translation of Tantum ergo

\author{
Tantum ergo sacramentum \\ Veneremur cernui \\ Et antiquum documentum \\ novo cedat ritui \\ Praestet fides supplementum \\ Sensuum defectui \\ Genitori, Genitoque \\ Laus et jubilatio \\ Salus, honor, virtus quoque \\ Sit et benedictio \\ Procedenti ab utroque \\ Compar sit laudatio. Amen.
}

Let us therefore bowing low

Venerate so great a sacrament;

And let the old law give way to the new rite;

Let faith afford assistance to the deficiency of the senses.

To the Begetter and the Begotten

Let there be praise and jubilation,

Salvation and honor and power and blessing.

And to the One proceeding from both

Let there be equal praise. Amen.

The first phrase of the chant moves from $\mathrm{E}$ to $\mathrm{C}$, the pitch emphasized in the second phrase. The chant melody emphasizes $\mathrm{G}$ as well: three of the six phrases end on $\mathrm{G}$, and one phrase begins on $\mathrm{G}$.

A motive consisting of a descending melodic line approached from below by step or minor third leap permeates the chant. (See Example 48, motive a.) 
Example 48. Prominent melodic motives in the chant
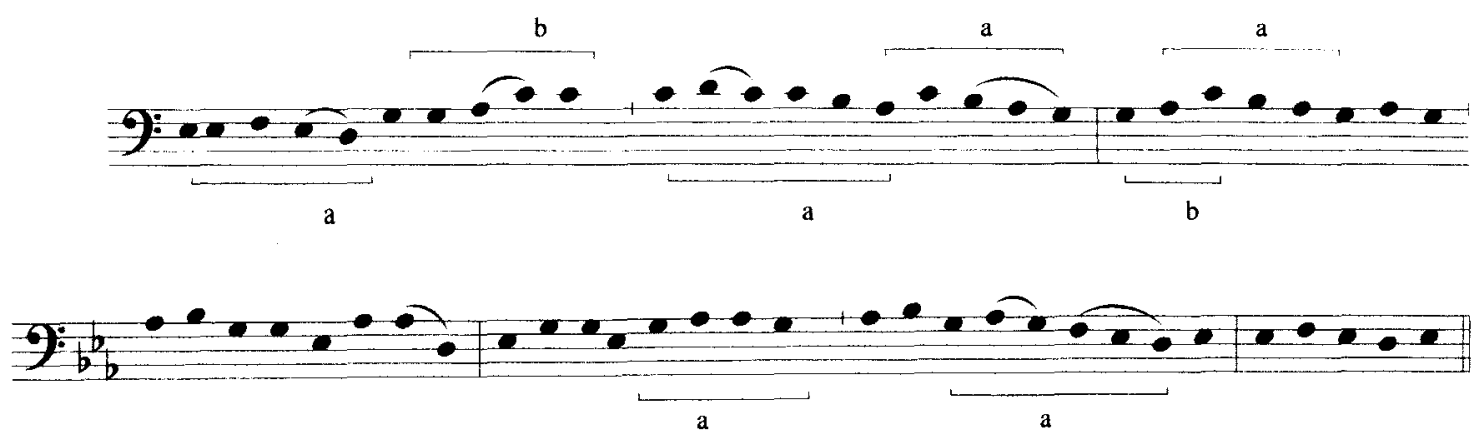

This motive, in the form of A-C-B-A-G, links the second and third phrases, concluding the second phrase and immediately reappearing in the third. Another prominent motive consists of a step followed by a third in the same direction (Example 48, motive b); this is featured in the first and third phrases.

Durufle places the entire chant in the soprano line, unmodified until the Amen except for its transposition to G Phrygian, while the tenor imitates the soprano at a lag of one to three beats, deviating from the soprano melody in rhythm and occasionally in octave and pitch. Example 49 shows the soprano/tenor canon, which extends throughout the motet and the Amen. 
Example 49. Soprano/tenor canon in Tantum ergo
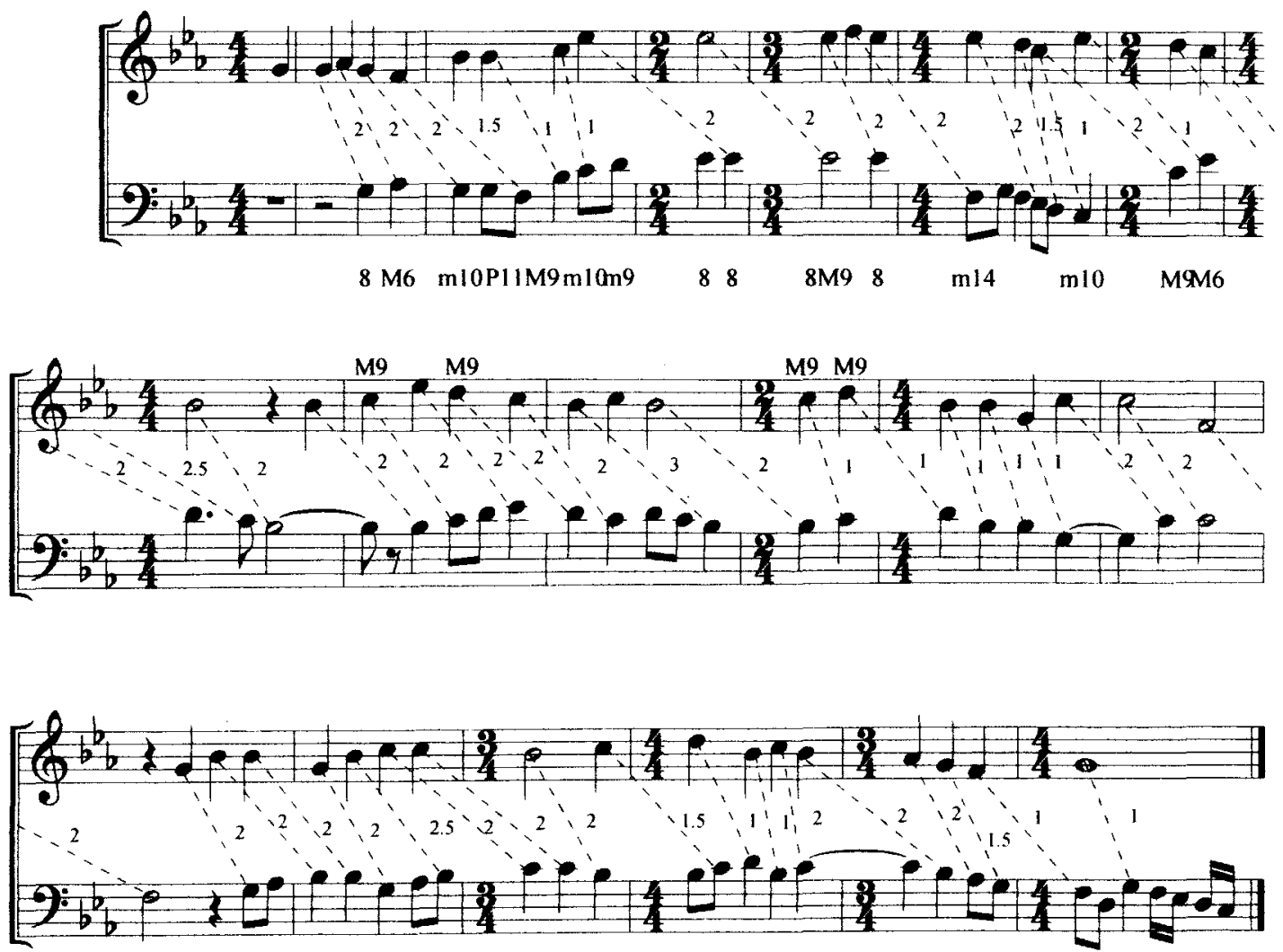

(O) 1960 Fditions Durand Paris, Franct

D. \&.F. 13901

Tous droits riseryés pour tous pays.

The numeral on the dotted line reflects the number of metric beats between the soprano and the corresponding tenor pitch. The temporal distance between the two voices varies from one to three beats due to repeated pitches in the tenor line, modified note and rest durations, and passing tones and other added notes. The soprano's initial lead is three beats, although it finishes only two beats ahead of the tenor. Apart from sub- 
metrical notes, dissonance between canonic voices is confined to a major ninths and major sevenths, which are numerous. The vertical intervals between the two parts are indicated beneath the first system. Parallel ninths occurring in the middle system reflect the parallelism characteristic of impressionism.

Two embedded descending G Phrygian scales are distributed among the four voices. Both begin new phrases, and both end at structurally significant cadence points. Example 50 sketches these.

Example 50. Embedded Phrygian scales

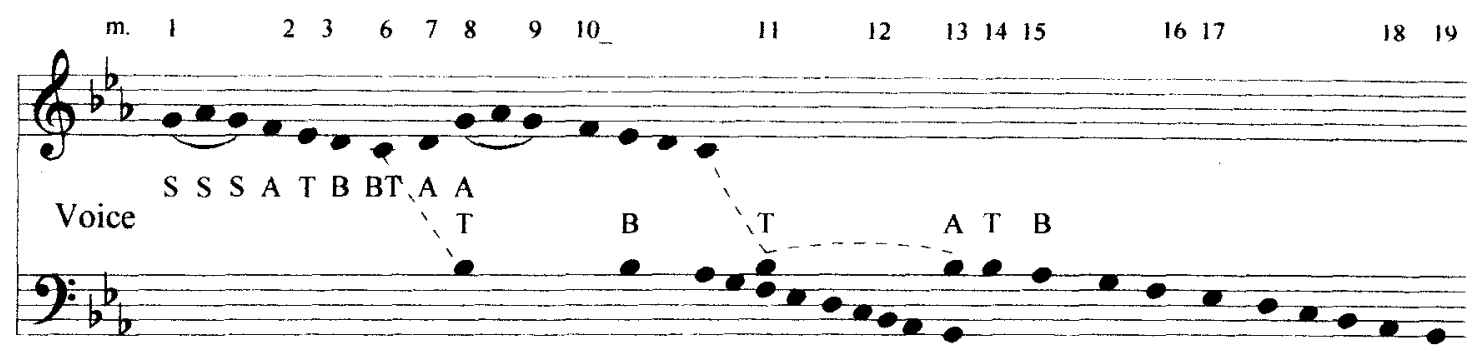

Both lines begin on $\mathrm{G} 4$, embellished by its upper leading tone $\mathrm{Ab4}$, and conclude on G2. The beginnings as well as the endings of these lines thus emphasize the characteristic Phrygian 2-1 half step.

The cadential formula that closes each verse of the chant (Ab-G-F-G in Duruflé's transposition) is incorporated into two cadential passages, mm. 5-7 and mm. 18-19. The first of these cadences is shown in Example 51. 
Example 51. Contrary motion in the cadential formula in mm. 5-7

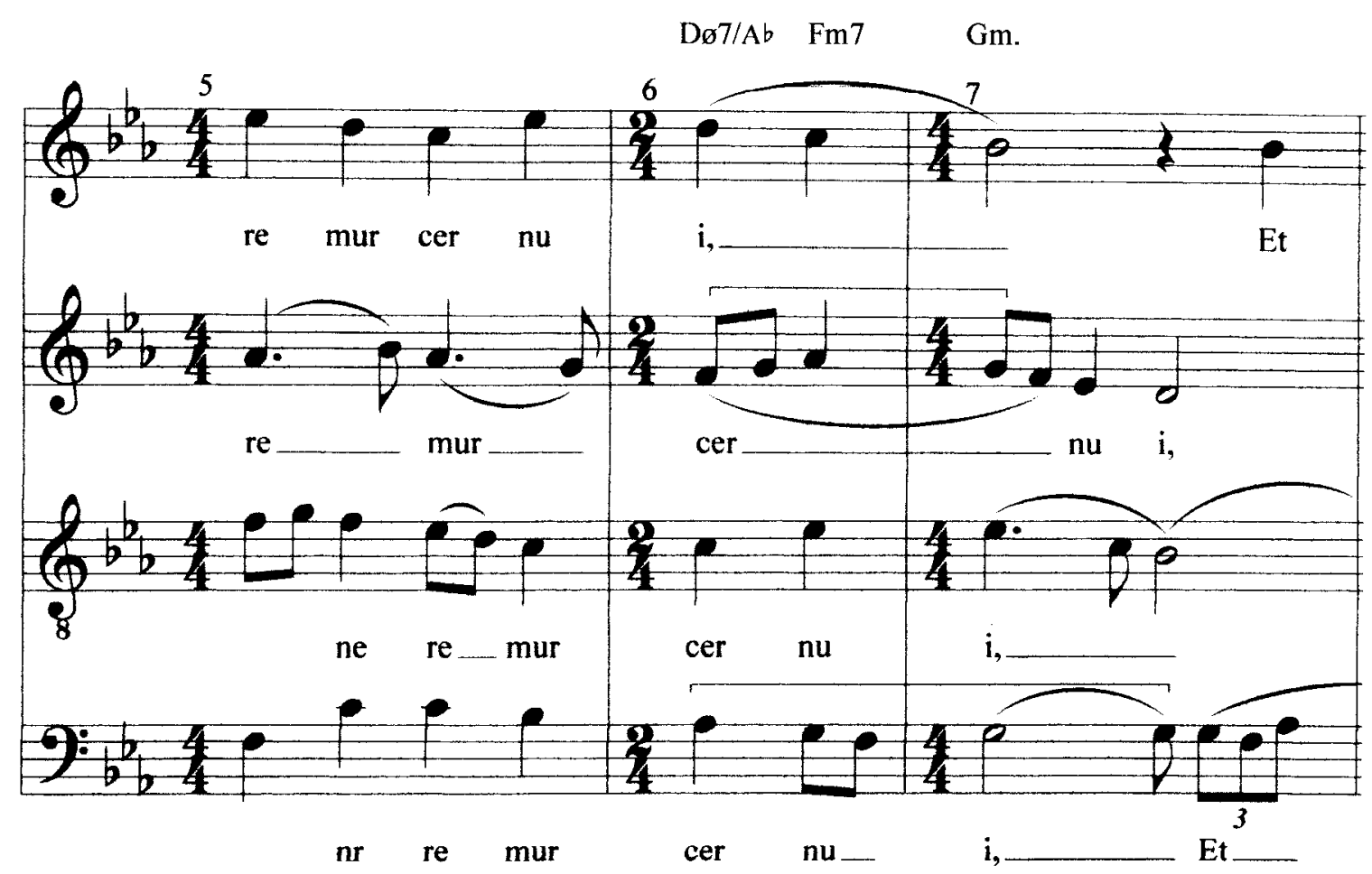

(3) letio Editions Duand Patis. Fianct

D. . F. 13901

Touts druts resergas frowr lous pars

In mm. 6-7, the Ab-G-F-G formula in the bass line is combined with its inversion

in the alto line. The counterpoint derived from the linear cadential formula is the foundation of the cadential harmonic succession, Dø7-F m7-Gm. 
The cadence of mm. 17-19 likewise incorporates the cadential motive, here presented in stretto in multiple transpositions. These are marked with brackets in Example 52.

Example 52. Cadence, mm. 17-19, with cadential formula at multiple transpositional levels

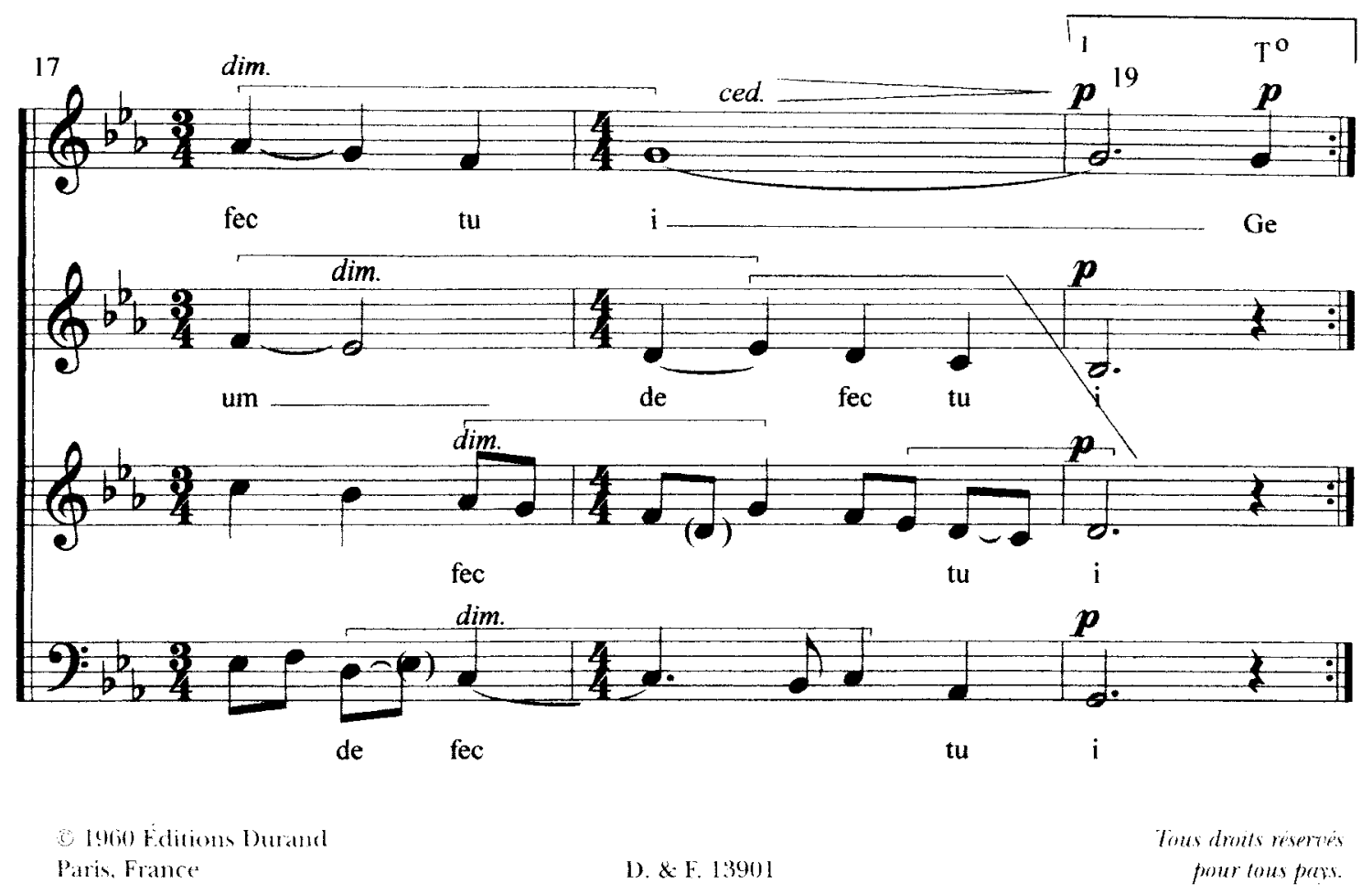

A few of these statements of the cadential motive add embellishing tones (shown in parentheses in Ex. 52). The two alto statements overlap, and the second of these is completed in the tenor. The soprano-bass counterpoint, F-G over Ab-G, further contributes to the strongly Phrygian character of the cadence. 
The second ending, shown in Example 53, also recalls the Ab-G-F-G cadential

formula. The soprano retains the contour of the line but changes the penultimate note to

D. The tenor has an incomplete statement, Ab3-G3-F3; this is completed with the alto G3

an eighth note later.

Example 53. Final cadence, mm. 19-21

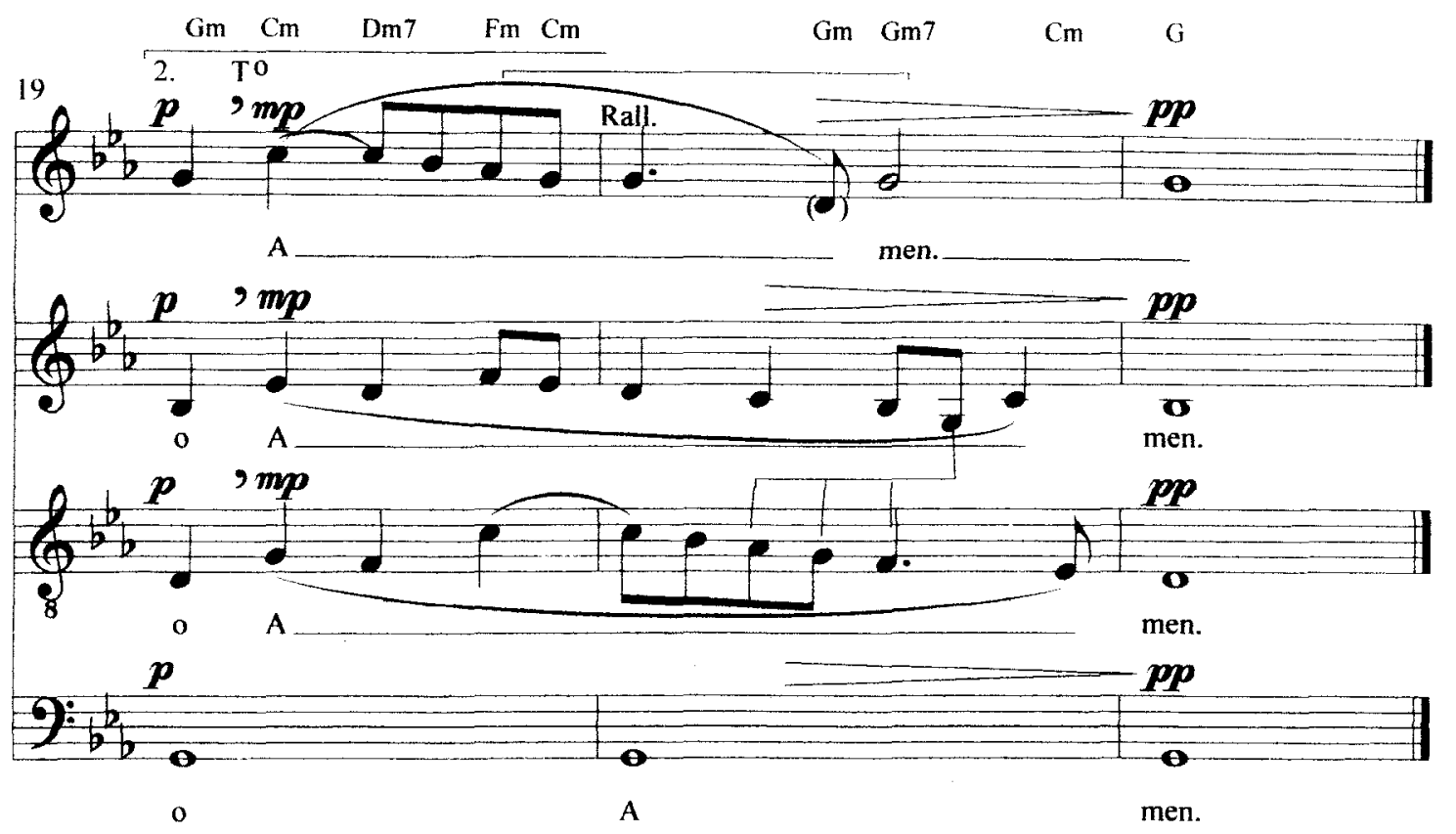

(8) 1960) Editions Durand 
Dissonant tones enrich the harmony of the closing measures, but the foundation is clear. As the bass intones a $\mathrm{G}$ pedal point, the upper voices move from the $\mathrm{G}$ minor cadential chord on the downbeat of $\mathrm{m}$. 19 to $\mathrm{C}$ minor; $\mathrm{C}$ minor reappears several times, interspersed with Dm7, Fm, and Gm7. The entire second ending thus suggests a prolonged plagal cadence.

The mezzo piano marked at the beginning of the Amen, the loudest indication in the motet, diminishes to the pianissimo of the final measure. Duruflé's setting of the hymn, with its low volume, slow pace, and somber mood, creates an ambience appropriate for the text and intention of the chant. 


\section{CHAPTER IV ENDNOTES}

1. McDowell Fogle, "Notes on Today's Music" (worship aid of St. Mark's Episcopal Church, Louisville, KY, January 30, 2010).

2. The New American Bible. New York: Oxford University Press, 1995. 


\section{CHAPTER V}

\section{CONCLUSION}

Duruflé's profession as a sacred musician and the influence of teachers and associates resulted in the inclination toward a conservative musical discourse in his vocal compositions and a harmonic palette reflecting French impressionism in his organ pieces. Both genres are deeply influenced by Gregorian chant, which informs the style of Duruflé's melodic composition as well as serving as a basis for cantus firmus technique and a source of motivic material.

Impressionism leaves its mark in quintal-quartal harmonies, chord planing, movement by tritones and thirds to distantly related centric regions, and exotic scale references. The impressionistic combination of chromaticism and modality which typifies Duruflé's harmonic language manifests itself in both Opus 4 and Opus 10.

Duruflé's compositional technique does not prolong melodic or harmonic gestures in the tonal sense. Instead, his "composing out" takes the form of developing melodic and rhythmic fragments. Forms and procedures from the tonal period are very much in evidence, however, in the guise of imitative counterpoint, variation technique, and small part-forms. 
The Prélude, Adagio, et Choral varié employs the chant melody Veni Creator Spiritus throughout, although a complete statement is withheld until the final movement. Duruflé consistently places the chant in surroundings incongruent with the textural and scalar simplicity of traditional chant-based compositions. In the first two movements, motives from the phrases of the cantus firmus are developed to such an extent that only the melodic contour of the chant is recognizable. Scalar material is exotic; Duruflé includes passages incorporating octatonic hybrid collections and a variety of modal collections.

The four motets are composed for liturgical use, and Duruflé seems to have considered the human voice and ear and the spiritual needs of the assembly in their composition. To comply with the Benedictine instructions concerning the rhythmic interpretation of chant, Duruflé changes meter frequently, and the expression of the text is paramount in the motets. The chant retains its church mode, and the lush harmonic environment in which it is set usually is diatonic, favoring tertian harmonies (including liberal doses of triads, seventh chords and ninth chords), with accented neighboring tones and appoggiaturas. The chant is used in both polyphonic and homophonic textures and is not limited to a particular vocal section.

Duruflé's oeuvre should be considered a worthy contribution to the music of the twentieth century. It deserves additional scholarly attention, and it is hoped that this thesis has provided some analytical commentary that will stimulate further research. 


\section{REFERENCES}

Alviani, Henry Anthony. "Use of Cantus Firmus in Selected Sacred Choral Works of Hugo Distler and Maurice Durufle." Master's thesis, California State University, Fullerton, 1980.

Brookins, John Barton. "The Use of Chant in the Choral Works of Maurice Duruflé." Master's thesis, Southwestern Baptist Theological Seminary, 1988.

Bunn, J. Gregg. "A Performer's Study of Three Préludes and Fugues for Organ Representing Eighteenth Century Germany, Nineteenth Century Germany, and Twentieth Century France: Johann Sebastian Bach, Franz Liszt, and Maurice Duruflé.” Document, Southwestern Baptist Theological Seminary, Fort Worth, TX, 2004.

Caldwell, Rodney Hildred. "Rhythmic and Metrical Groupings of Chant Notation as an Influence Upon the Conducting for the Quatre Motets sur des thèmes grégoriens, Op.10, of Maurice Duruflé." Document, The University of Arizona, 1995.

Cooksey, Steven Lee."Impressionistic Aspects of Twentieth-Century French Organ Literature." Ph.D. diss., Washington University, 1972.

Cox, Carol Luikart. "The ‘Suite for Organ' by Maurice Duruflé." Master's thesis, University of Rochester, Eastman School of Music, 1960.

Driscoll, Brian Scott. "Maurice Duruflé's Prélude, Adagio et Choral varié sur le theme $d u$ 'Veni Creator': A performance guide." D.M.A. diss., University of California, Los Angeles, 2004.

Dorroh, William James, Jr. "A Study of Plainsong in the Organic Compositions of Six Twentieth-Century Composers." Ph.D. diss., George Peabody College for Teachers, 1978.

Duruflé, Maurice. "My Recollections of Charles Tournemire and Louis Vierne." Musical Opinion, 103, No. 10 (1979): 5-8. 
Eaton, Robert P. "Maurice Duruflé's Requiem: Op.9 An Analysis for Performance." Master's thesis, University of Hartford, 1991.

Ebrecht, Ronald. ed., Maurice Duruflé 1902-1986: The Last Impressionist. Lanham, MD: Scarecrow Press, 2002.

Fazio, Leanne Hemphill. "Selected organ settings of 'Veni Creator Spiritus' from 1470-1964: A historical perspective." D.M.A. diss., The University of Alabama, 1990.

Frazier, James E. Maurice Duruflé: The Man and His Music. Rochester, NY: University of Rochester Press, 2007.

Jarjisian, Peter. "The Influence of Gregorian Chant on Maurice Duruflé's Requiem, Opus 9." Ph.D. diss., The University of Wisconsin, 1991.

Kano, Thea. "Visions of aTranquil End: The Expressive and Stylistic Interpretation of Maurice Durufle's Requiem, Opus 9.” D.M.A. diss., University of California, Los Angeles, 2004.

McCandless, William Edgar. "Cantus Firmus Techniques in Selected Instrumental Compositions 1910-1960.” Ph.D. diss., Indiana University, 1974.

McIntosh, John Stuart. "The Organ Music of Maurice Duruflé.” D.M.A. diss., University of Rochester, 1973.

McIntosh, William John. "Modal and Rhythmic Implications of Gregorian Chant Themes Used in the Choral Music of Maurice Duruflé." Project Report, California State University, Long Beach, 1999.

Mendoza, Michael D."The Use of Chant and the Influence of the Solesmes Method of Chanting in the Compositional Style of Maurice Duruflé's Messe Cum Jubilo." Ph.D. diss., The University of Arizona, 1984.

Morrison, Donald Nauman. "Influences of Impressionist Tonality on Selected Works of Delius, Griffes, Falla, and Respighi, Based on the Concept Developed by Robert Mueller." Ph.D. diss., Indiana University, 1960.

Reynolds, Jeffrey W. "The Choral Music of Maurice Duruflé." Master's thesis, University of Illinois, 1991. 
Rhoades, Larry Lynn. "Theme and Variation in Twentieth-Century Organ Literature: Analyses of Variations by Alain, Barber, Distler, Dupré, Duruflé, and Sowerby." Diss., The Ohio State University, 1973.

Rubis, Marie E. "Larger Metric Structures in Two Organ Works by Maurice Duruflé." D.M.A. diss., University of Kansas, 1991.

Singley, Henry Ellis III. "A Survey of French Choral Music of the Twentieth Century with a Performance and Interpretive Analysis of Selected Works." Ed.D. diss., Columbia University, 1968.

Spillman, Herndon "The Organ Works of Maurice Duruflé." D.M.A. diss., Indiana University, 1976.

Sprout, Leslie A. "Music for a 'New Era': Composers and National Identity in France, 1936-1946." Ph.D. diss., University of California, Berkeley, 2000.

Volante, Harry Robert. "A Survey of French Choral Music of the Twentieth Century with a Performance and Interpretive Analysis of Selected Works." Ed.D. diss., Columbia University, 1968.

van Wye, Benjamin David. "Gregorian Influences in French Organ Music before the Motu proprio." Journal of the American Musicological Society, Vol. 27, No. 1 (Spring, 1974): 1-24.

Zehr, Maria Goretti. "Selected Organ Compositions Based Upon the Hymn Veni Creator Spiritus." D.Mus. diss., Indiana University, 1979 


\section{CURRICULUM VITAE}

NAME:

Charlyn Denice Brownlee Dumm

ADDRESS:

4005 Cumberland Drive

La Grange, KY. 40031

DOB:

Galveston, Texas - July 26, 1953

EDUCATION:

B.A. Music, University of Houston, cum laude Journeyman Photoengraver Certification

AWARDS:

Outstanding Young Women of America 1982

National Merit Commendation Scholar 1971

Moody Foundation Scholar 1971-74

PROFESSIONAL SOCIETIES: Society for Music Theory Union of Industrial Graphic Artists

Phi Mu Fraternity

Golden Key Honor Society

American Guild of Organists

EXPERIENCE: $\quad$ Courier Journal production work 1974-2004 Louisville Orchestra Masterworks Chorale 1990-1995

Minister of Music, Metropolitan Community Church of Louisville, 1993-2003

Pastoral Staff, Metropolitan Community Church of

Louisville, 1997-2002 